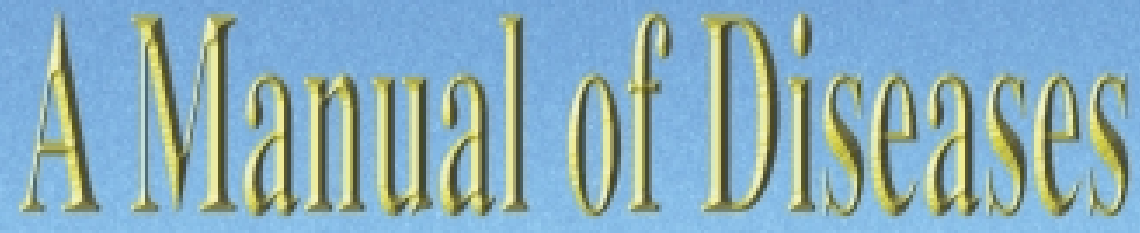

$$
\text { of }
$$

$$
\text { Tropical Acacias }
$$

III

Alustralla, South. Fast Asia and Indìn

Kenmeth MI. OId Lee Su See Jyoti IK. Sharma - Ji

$$
\text { Qfing Yuan: }
$$

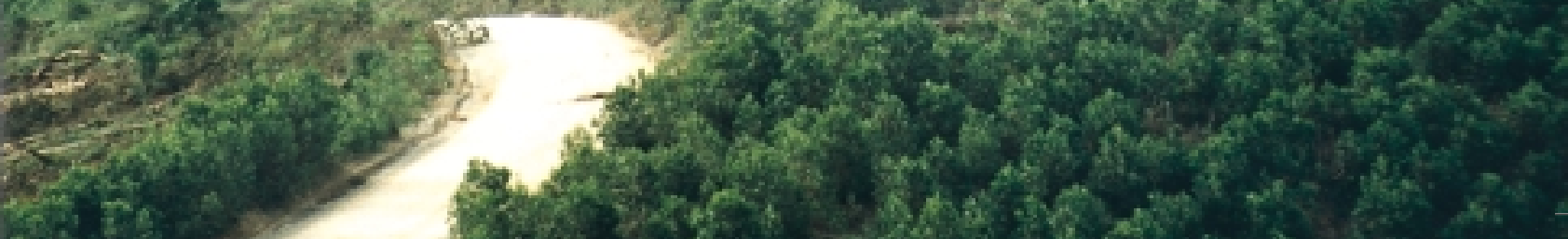




\section{A Manual of Diseases of \\ Tropical Acacias in \\ Australia, South-East Asia and India}

Kenneth M. Old

CSIRO Forestry and Forest Products

Australia

Lee $\mathrm{Su}$ See

Forest Research Institute of Malaysia

Malaysia

Jyoti K. Sharma

Kerala Forest Research Institute

India

Zi Qing Yuan

University of Tasmania

Australia

Center for International Forestry Research 
A manual of diseases of tropical acacias in Australia, South-East Asia and India. 104 p.

K.M. Old, Lee Su See, J.K. Sharma, Zi Qing Yuan

(C) 2000 Center for International Forestry Research

Published by:

Center for International Forestry Research

PO Box 6596, JKPWB

Jakarta 1006

Indonesia

ISBN 979-8764-44-7

With the support of:

CSIRO Forestry and Forest Products

PO Box E4008

Kingston ACT 2604

Canberra, Australia

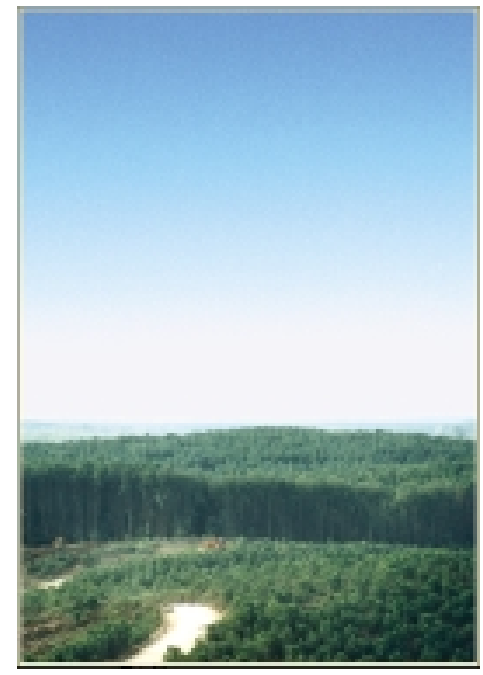

Cover Photograph: Ken Old

Healthy first and second rotation plantations of Acacia mangium near Pekanbaru, North Sumatra

Design and production: Vlad Mosmondor

CSIRO Forestry and Forest Products

Canberra, Australia 


\section{CONTENTS}

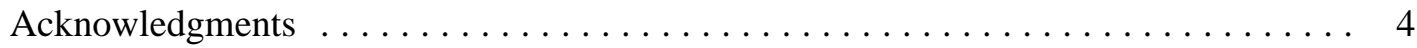

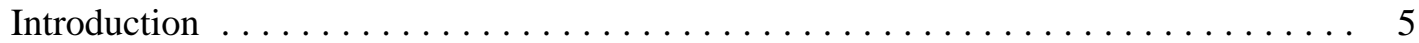

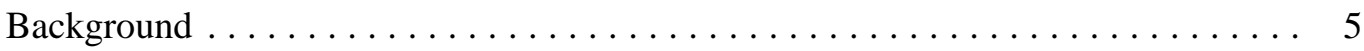

Diseases of Tropical Acacias . . . . . . . . . . . . . . . . . . . . . . . 5

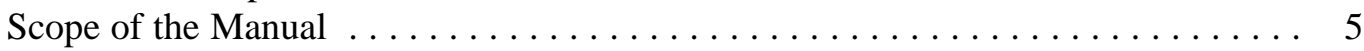

Overview of Diseases of Tropical Acacias in Australia, South-East Asia and India $\ldots 6$

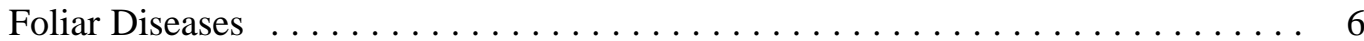

Stem Canker Diseases ................................. 7

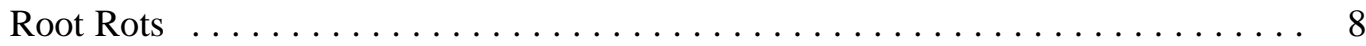

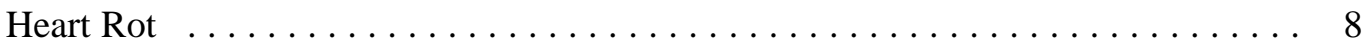

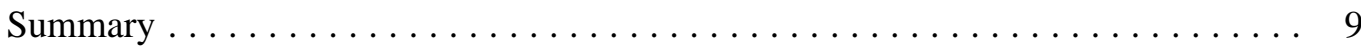

References ................................. 9

Key to Diseases and Pathogens Described in this Manual .............. 12

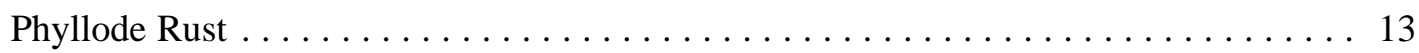

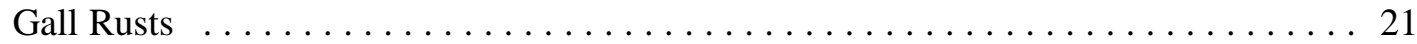

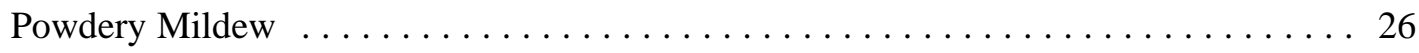

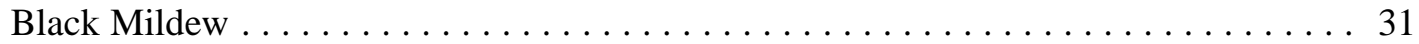

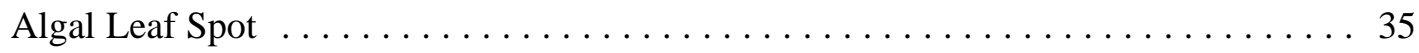

Cylindrocladium Foliar Spot and Foliar Blight $\ldots \ldots \ldots \ldots \ldots \ldots \ldots \ldots \ldots$

Cercospora and Pseudocercospora Foliar Disease . . . . . . . . . . . . . . . 44

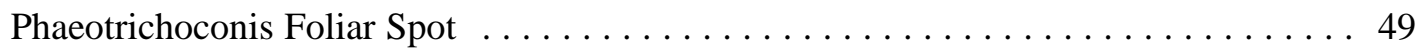

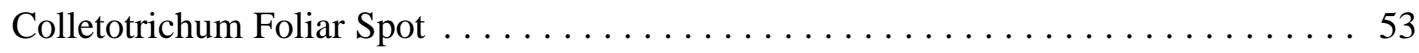

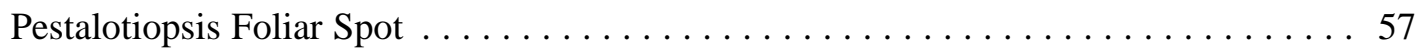

Phomopsis Foliar Spot $\ldots \ldots \ldots \ldots \ldots \ldots \ldots \ldots \ldots \ldots \ldots \ldots \ldots \ldots \ldots \ldots \ldots \ldots$

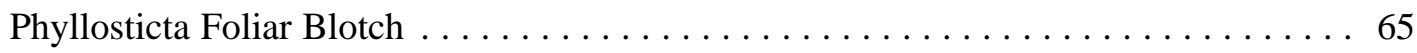

Pink Disease . . . . . . . . . . . . . . . . . . . . . . . . . . . . . . . 69

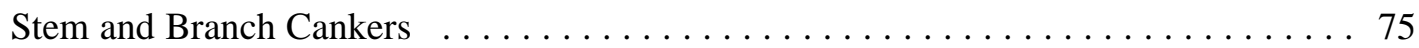

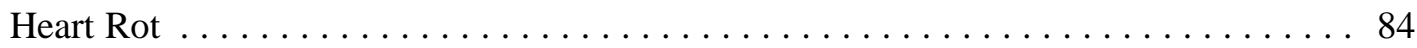

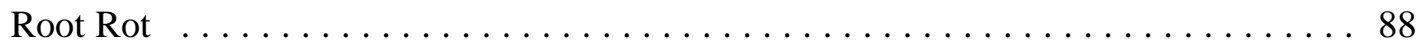

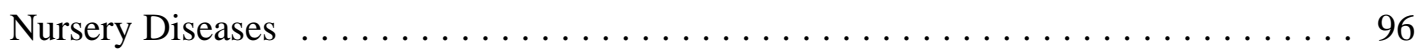

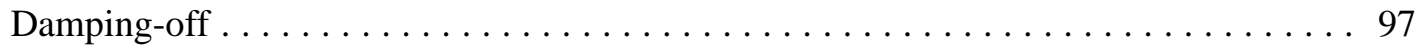

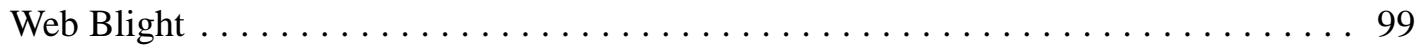

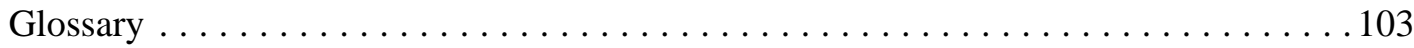




\section{ACKNOWLEDGMENTS}

The preparation of this manual was made possible by financial support received from the Center for International Forestry Research (CIFOR) and the Australian Centre for International Agricultural Research (ACIAR). The authors have been supported throughout by their respective organisations, CSIRO being the managing agency. We thank the above organisations for their encouragement and sustained support in bringing this manual to completion. Thanks are also due to Dr Mike Ivory and Mr Alan Brown for critical reading of the manuscript and to $\mathrm{Mr}$ Mark Dudzinski for assistance with bibliographical references. Design and supervision of the production and printing was ably carried out by Mr Vlad Mosmondor. Mycological drawings were prepared by Dr Zi Qing Yuan and the text written by the other three authors who also took most of the photographs. Figs 25, 27, 28, $30,63,64$ and 65 were kindly provided by Ms Krisna Pongpanich.

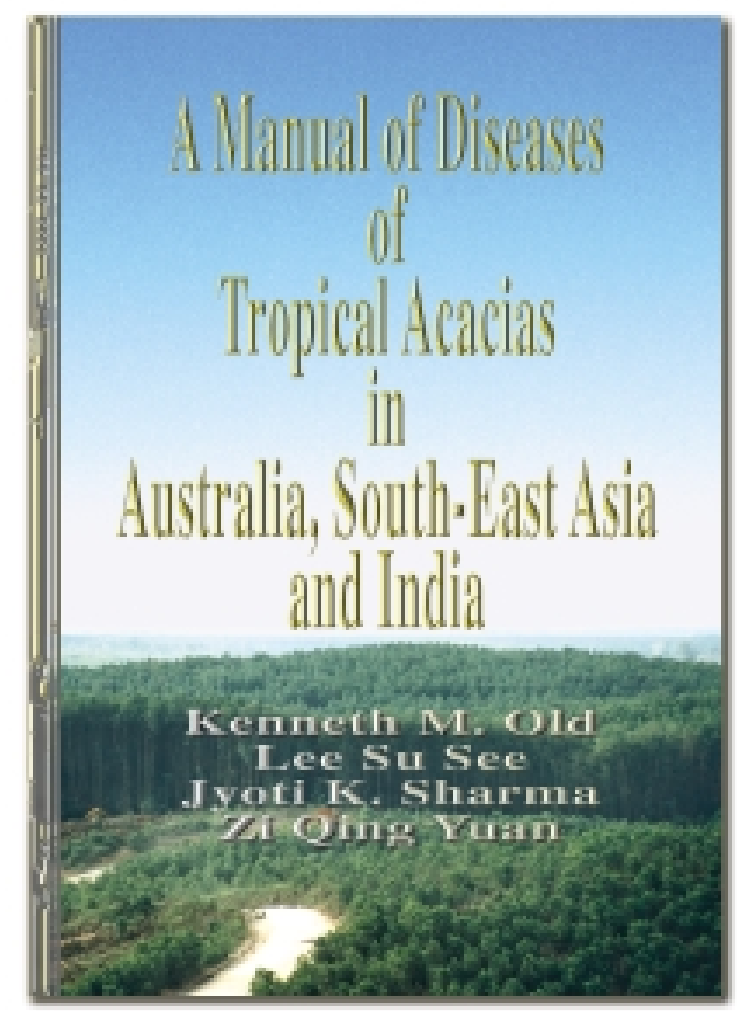




\section{INTRODUCTION}

\section{Background}

Acacias are of considerable social and industrial importance for tropical reforestation, with about 2 million ha worldwide. The last few decades have seen a major expansion of plantations for industrial use, especially in South-East Asia. Both native and exotic species of Acacia are also widely grown in the Indian sub-continent. Turnbull et al. (1998) reviewed the status of tropical acacia plantations in Asia.

The species which have been most widely planted so far in industrial plantations in South-East Asia are Acacia mangium Willd. and A. auriculiformis Cunn. ex Benth. A. crassicarpa Cunn. ex Benth. and A. aulacocarpa Cunn. ex Benth. provenance and species trials have been established in many locations throughout the region to provide options for future hardwood plantations. Commercial plantings of A. crassicarpa have recently been established in Indonesia.

\section{Diseases of tropical acacias}

Plantations of acacias in the humid tropics have been relatively free of disease compared to eucalypts that are commonly damaged by disease in such environments. Reports from several countries in South-East Asia and northern Australia have, however, suggested that the future productivity of acacia plantations may be affected by fungal pathogens.

During 1995-96, surveys of diseases of the four Acacia species mentioned above were carried out in northern Australia and several countries of South-East Asia, supported by funding from the Australian Centre for International Agricultural Research (ACIAR) and the Center for International Forestry Research (CIFOR). The surveys by forest pathologists were undertaken in native stands, trials and industrial and social forestry plantations of tropical acacias in Australia, India, Indonesia, Malaysia and Thailand. The objectives were to assess the potential of fungal pathogens as limiting factors to tree growth and productivity, and to compare the relative importance of individual fungal pathogens.

The findings were published in the proceedings of a workshop held at Subanjeriji in Sumatra in 1996 (Old et al. 1997), providing a benchmark of the current knowledge of the pathology of Acacia plantations in tropical areas of South-East Asia. The most significant diseases were considered to be foliar spots and necrosis, powdery mildew, rusts, stem cankers, root and butt rots and heart rot. Research managers of several of the principal plantation, pulp and paper companies in Indonesia attended the workshop. They suggested that an illustrated manual of the more common diseases of the acacias grown in industrial plantations in the tropics would be extremely useful to plantation managers, and requested that such a manual be written. The authors of this book have responded to this request with support from their respective organisations and financial assistance from ACIAR and CIFOR.

\section{Scope of the manual}

The importance of A. mangium, A. auriculiformis, A. crassicarpa and A. aulacocarpa and their potential for plantation establishment has been stressed by Matheson and Harwood 
(1997). Consistent with the aims of the initial project the focus on these species is maintained, with reference to some other species where appropriate. The manual is not intended to be a full account of all diseases recorded on acacias in the tropics. Comprehensive lists of acacia diseases for northern Australia, India and South-East Asia are presented in the proceedings of the Subanjeriji workshop (Old et al. 1997). Boa and Lenné (1994) provided a list of diseases of nitrogen-fixing trees in developing countries and Gibson (1975) published a summary of diseases of trees (including acacias) which are widely planted in the tropics. This manual aims to provide managers with short, illustrated accounts of the main diseases which they are likely to encounter in plantations, with useful references to published reports. Each description is accompanied by colour photographs of disease symptoms taken in the field by the authors.

The ease of identification of causal agents of tree diseases is very variable. In some cases microscopic examination of infected tissue and culturing of pathogens is required to establish cause. In other cases, for example heart rot, the identity of the fungi present in stem tissue is not so critical, as control measures can be equally effective against a range of pathogens that invade stems in a similar way. To ensure that adequate information is presented to identify pathogens, each disease description is accompanied by detailed mycological drawings prepared from fresh or herbarium specimens. These descriptions and drawings of the microscopic characteristics of the pathogens should make possible the identification, to genus or species, of pathogens associated with the diseases. A guide to basic plant pathological and mycological techniques has been provided by Johnston and Booth (1983).

\section{OVERVIEW OF DISEASES OF TROPICAL ACACIAS IN AUSTRALIA, SOUTH-EAST ASIA AND INDIA}

The diseases can be grouped based on the part of the tree which is infected as summarised below.

\section{Foliar diseases}

The 'leaves' of the acacias dealt with here, with the exception of true leaves produced by young seedlings, are more properly referred to as phyllodes, and this term will be used throughout. Phyllodes often show a range of fungal spots, blotches and tip necrosis symptoms. Associated pathogens include species of Cercospora, Colletotrichum, Cylindrocladium, Pestalotiopsis, Phomopsis, Phaeotrichoconis, Phyllosticta and Pseudocercospora. In some situations a significant proportion of tree crowns, especially foliage borne on lower branches, can be affected but the impact on growth is generally uncertain. In other situations infection of foliage and shoots clearly has serious consequences.

Powdery mildew, caused by a species of Oidium, can be found on seedlings in most nurseries where tropical acacias are grown. Mildew is also occasionally found, in humid conditions, on phyllodes of lower branches or coppice shoots under canopies of established plantations. Damage to young nursery seedlings can be severe and cases of up to $75 \%$ mortality have been reported in Thailand (Tanaka and Chalermpongse 1990). Black mildew caused by species of Meliola is also common in young plantations but has little or no effect on tree growth. 
One of the more important and damaging phyllode diseases is caused by a rust fungus, identified as Atelocauda digitata. This fungus occurs commonly in northern Australia on a wide range of species (McAlpine 1906) and has been found infecting nursery stock and plantation trees of A. mangium and A. auriculiformis in Java, central and southern Sumatra, and several locations in Kalimantan (Old 1998). Research is needed to confirm the identity of this pathogen, to determine whether strains of the rust vary in pathogenicity and to assess the capacity of $A$. digitata to reduce plantation growth. There appears to be considerable variation between provenances in susceptibility to disease, indicating a potential for selection of resistant genotypes. In view of the ability of rusts to spread and cause diseases of epidemic proportions, strategies for future selection of clones for widespread planting should include evaluation for rust resistance.

Although $A$. digitata, which principally attacks phyllodes, young shoot tips and pods appears to be the most common rust on plantation acacias in the tropics, Uromycladium tepperianum which occurs on both tropical and temperate acacia species in Australia (McAlpine 1906; Old et al. 1997; Dick 1985) is also of concern. This fungus and its close relative $U$. notabile have been long recognised as major acacia pathogens. Rust galls occur on woody stems and branches, phyllodes, inflorescences and fruit. Affected stems can be girdled and highly susceptible individuals are sometimes killed. U. tepperianum has been introduced into South Africa in an attempt to control A. saligna, an important weed (Anon. 1987). Acacia rusts were not recorded in the surveys in India, Thailand nor Malaysia. However, a collection resembling A. digitata was made on acacia phyllodes in Hong Kong (reported by Cannon et al. 1997) and there are unconfirmed reports of the pathogen elsewhere in southern China.

\section{Stem canker diseases}

Cankers are areas of necrotic bark and outer sapwood that result from the invasion of stems by a range of fungal pathogens. Typical avenues for invasion by canker-causing fungi are wounds, branch stubs left after pruning, incomplete occlusion of suppressed lower branches and insect damage. Trees subjected to stress such as drought, defoliation by foliar pathogens or insects, nutrient limitation or growth suppression are often more susceptible to canker pathogens than are vigorous trees well matched to the site. Severe canker diseases were reported from surveys in three separate countries, India, Indonesia and Thailand (Hadi and Nuhamara 1997; Pongpanich 1997; Sharma and Florence 1997).

Pathogens associated with cankers and their role in canker formation are difficult to determine with certainty, although Lasiodiplodia theobromae and a species of Phomopsis have been isolated from cankered stem tissue (Hadi and Nuhamara 1997) in Indonesia. In India Nattrassia mangiferae (syn. Hendersonula toruloidea) was found to cause a serious canker disease of both A. mangium and A. auriculiformis (Sharma and Florence 1997) and in Thailand Botryosphaeria sp. was most commonly associated with cankers (Pongpanich 1997).

Perhaps the best known canker disease associated with tropical acacia plantations is pink disease. This disease is caused by the basidiomycete fungus, Corticium salmonicolor, which has a very wide host range, including rubber (Hilton 1958), eucalypts (Sharma et al. 1984), A. mangium (Hadi and Nuhamara 1997; Zulfiyah and Gales 1997), A. crassicarpa and A. aulacocarpa (Hadi and Nuhamara 1997) and A. auriculiformis (Florence and Balasundaran 1991). The pathogen is especially active in high-rainfall areas where many susceptible plantation species such as tropical fruit trees, cocoa, coffee and other crops are grown. Access to stems can occur through healthy bark tissue. In the field, the disease comes to notice 
through stem breakage, often high in the crown of the tree. The disease occurs in patches in stands that are overstocked or stressed by other environmental factors. Zulfiyah and Gales (1997) found this to be the most prevalent disease in A. mangium in South Sumatra and related incidence of pink disease to stand density, with denser stands being worse affected. Pink disease has been recorded on tropical acacias in Kalimantan (Hadi and Nuhamara 1997) and in India (Sharma and Florence 1997), but has not been reported as a significant disease on plantation acacias in Thailand, Malaysia or Australia.

\section{Root rots}

Trees in tropical rainforests are hosts to a range of root and butt rot pathogens, typically of the genera Phellinus, Rigidoporus and Ganoderma (Lee 1997). In undisturbed native forests these fungi probably exist in equilibrium with their hosts, causing the death of scattered trees but rarely causing disease at a level threatening stand survival. The fungi have wide host ranges and when tropical rainforests are cleared and planted to acacias, inoculum surviving on roots and stumps of dead trees commonly invades roots of newly planted trees, causing tree death. As these fungi spread underground by growth in soil, or by root contact between healthy and diseased trees, the result is an expanding patch of dying and dead trees.

Root rot was the most widespread disease in A. mangium plantations surveyed in Peninsular Malaysia, but has been observed less frequently in stands established on areas long cleared of forest in South Sumatra and South Kalimantan. A. mangium is regarded as a very useful species in these areas where it successfully suppresses growth of alang alang (Imperata cylindrica). The low incidence of root rot probably reflects a reduction in the abundance of fungal inoculum following earlier forest clearing, but the level of disease is likely to increase in subsequent rotations.

Root rot must be regarded as a serious threat to Acacia plantations established on recently cutover forest. The planting of successive rotations of acacias will provide a corresponding succession of susceptible trees. The ban on slash burning, imposed in Indonesia following high levels of atmospheric pollution from wildfires, may result in a build-up of inoculum on the slash of cut-over forests and residues remaining after plantation harvesting. As there is no practical means of control of these pathogens on a plantation-wide basis, careful monitoring will be needed over the next decade to establish the scope of this problem.

\section{Heart rot}

Heart rot is the only disease of tropical acacias that has been the subject of sustained research during the last decade (Lee et al. 1988, 1996; Lee and Maziah 1993). The condition has been reported in Peninsular Malaysia, Sabah (Mahmud et al. 1993; Ito and Nanis 1997) and India (Mehrotra et al. 1996). There are unpublished reports of heart rot in Thailand, Indonesia and the Solomon Islands.

Research by Lee and associates has showed that stem defect is closely associated with branch stub infections, singling wounds and forking (Lee et al. 1988; Ito 1991; Mahmud et al. 1993). Although incidence of heart rot can be very high, 50\%-98\% of trees being affected, the volume of wood affected can be quite small. This level of degrade is serious where wood is used for construction and appearance grades but is of little significance where the crop is grown for pulp and paper or composites on rotation lengths of 7-10 years. 
The causal agents of heart rot are basidiomycete fungi, and until recently there was little published information as to their identity. Phellinus noxius was reported from Peninsular Malaysia by Lee and Maziah (1993), and Ivory (1996) has reviewed diseases of forest trees caused by this fungus. Several other fungi have since been reported from Peninsular Malaysia and Kalimantan (Lee and Noraini Sikin 1999) and India (Mehrotra et al.1996).

The extent of heart rot in existing plantations may in part reflect the generally poor genotypes which were planted in the first wide-scale establishment of tropical acacia plantations in Malaysia and Indonesia, and the less than adequate silviculture. As provenances and clones with better form are established on second-rotation sites or new plantation areas, and silviculture improves, it can be expected that there will be fewer multi-stemmed trees requiring singling and pruning of heavy limbs. Fewer singling wounds and smaller branch stubs on trees of improved form will lead to reduced invasion by heart rot fungi. Wound treatment is not generally feasible, evidence for efficacy of treatment is lacking and such measures are time consuming and labour intensive.

\section{Summary}

Plantation forestry based on tropical acacias will need to consider diseases as major factors in management of stands for sustained productivity. The surveys in northern Australia and South-East Asia (Old et al. 1997) have established a current benchmark of the main pathogens present and an indication of which diseases may have a potential to impact on productivity. This manual provides a means by which plantation managers and forest health specialists in the region and elsewhere in the tropics can make preliminary identifications of fungal diseases affecting acacia plantations. Experience with plantation forestry in many parts of the world has shown that diseases can be managed to reduce impacts to an acceptable level. To achieve this, forest pathologists need to contribute to many aspects of plantation management including nursery hygiene, silviculture and site management, and tree improvement to minimise disease impacts during successive rotations.

\section{References}

Anonymous 1987. A fungus released to help control Port Jackson 'willow'. Plant Protection News. Plant Protection Research Institute, Pretoria, South Africa. Bulletin No. 8: 1-2.

Boa, E. \& Lenné, J. 1994. Diseases of Nitrogen Fixing Trees in Developing Countries: An Annotated List. Natural Resources Institute, Overseas Development Administration. $82 \mathrm{p}$.

Cannon, P., Pascoe, I., Beilharz, V. and Yuan, Z.Q. 1997. Report on fungi from diseased acacia samples examined at Institute of Horticultural Development, Knoxfield, Victoria. In: Old, K.M., Lee, S.S. and Sharma, J.K. eds. Diseases of Tropical Acacias. Proceedings of an international workshop, Subanjeriji (South Sumatra), 28 April - 3 May 1996. CIFOR Special Publication, 108-113.

Dick, M. 1985. Uromycladium rusts of acacia. Forest Pathology in New Zealand No. 15,8 p. 
Florence, E.J.M. and Balasundaran, M. 1991. Occurrence of pink disease of Acacia auriculiformis in Kerala. Indian Forester 117: 494-496.

Gibson, I.A.S. 1975. Diseases of Forest Trees Widely Planted as Exotics in the Tropics and Southern Hemisphere, Part I. Important members of the Myrtaceae, Leguminosae, Verbenaceae and Meliaceae. Commonwealth Mycological Institute, CAB, U.K., 51 p.

Hadi, S. and Nuhamara, S.T. 1997. Diseases of species and provenances of acacias in West and South Kalimantan, Indonesia. In: Old, K.M., Lee, S.S. and Sharma, J.K. eds. Diseases of Tropical Acacias. Proceedings of an international workshop, Subanjeriji (South Sumatra), 28 April - 3 May 1996. CIFOR Special Publication, 23-47.

Hilton, R.N. 1958. Pink disease of Hevea caused by Corticium salmonicolor Berk. et Br. Journal of the Rubber Research Institute Malaya 15: 275-292.

Ito, S.I. 1991. A survey of heart rot in Acacia mangium. Report to SAFODA, 52 p.

Ito, S.I. and Nanis, L.H. 1997. Survey of heart rot on Acacia mangium in Sabah, Malaysia. Japan Agricultural Research Quarterly 31: 65-71.

Ivory, M.H. 1996. Diseases of forest trees caused by the pathogen Phellinus noxius. In: Forest Trees and Palms, Diseases and Control, Oxford and IBH Publishing Co Pty Ltd. New Delhi/Calcutta, 111-133.

Johnston, A. and Booth, C. 1983. Plant Pathologist's Pocketbook. Commonwealth Mycological Institute, Kew, England, 439 p.

Lee, S.S. 1997. Diseases of some tropical plantation acacias in Peninsular Malaysia. In: Old, K.M., Lee, S.S. and Sharma, J.K. eds. Diseases of Tropical Acacias. Proceedings of an international workshop, Subanjeriji (South Sumatra), 28 April - 3 May 1996. CIFOR Special Publication, 53-61.

Lee, S.S. and Noraini Sikin, Y. 1999. Fungi associated with heart rot of Acacia mangium trees in Peninsular Malaysia and East Kalimantan. Journal of Tropical Forest Science 11: 240-254.

Lee, S.S., Zakaria I., Hashim, M.N. and Wan Razali, W.M. 1996. Impact of heart rot in Acacia mangium Willd. plantations of Peninsular Malaysia. In: Nair, K.S.S., Sharma, J.K. and Varma, R.V. eds. Impact of Diseases and Insect Pests in Tropical Forests. Proceedings of IUFRO Symposium, November 1993. Kerala Forest Research Institute, Peechi, India, 23-26 November 1993, 23-28.

Lee, S.S. and Maziah, Z. 1993. Fungi associated with heart rot of Acacia mangium Willd. in Peninsular Malaysia. Journal of Tropical Forest Science 5: 479-484.

Lee, S.S., Teng, S.Y., Lim, M.T. and Razali Abd. Kader 1988. Discoloration and heart rot of Acacia mangium Willd. - some preliminary results. Journal of Tropical Forest Science 1: 170-177. 
McAlpine, D. 1906. The Rusts of Australia. Government Printer, Melbourne, Australia, 349 p.

Mahmud Sudin, Lee, S.S. and Ahmad Hj. Harun 1993. A survey of heart rot in some plantations of Acacia mangium Willd. in Sabah. Journal of Tropical Forest Science 6: $37-47$.

Matheson, A.C. and Harwood, C.E. 1997. Breeding tropical Australian acacias. Proceedings 24th Southern Forest Tree Improvement Conference, July 1997, Florida, 69-80.

Mehrotra, M.D., Pandey, P.C., Chakrabarti, K.S., Sharma, J.K. and Hazra, K. 1996. Root and heart rots in Acacia mangium plantations in India. Indian Forester 122: 155-160.

Old, K.M., Lee S.S. and Sharma, J.K. 1997. Diseases of Tropical Acacias. Proceedings of an international workshop, Subanjeriji (South Sumatra), 28 April - 3 May 1996. CIFOR Special Publication, $120 \mathrm{p}$.

Old, K.M. 1998. Diseases of tropical acacias. In: Turnbull, J.W., Crompton, H.R. and Pinyopusarerk, K. eds. Recent Developments in Acacia Planting. Proceedings of an international workshop, Hanoi, Vietnam, October 1997. ACIAR Proceedings No. 82: 224-233.

Pongpanich, K., 1997. Diseases of Acacia species in Thailand. In: Old, K.M., Lee, S.S. and Sharma, J.K. eds. Diseases of Tropical Acacias. Proceedings of an international workshop, Subanjeriji (South Sumatra), 28 April - 3 May 1996. CIFOR Special Publication, 62-69.

Sharma, J.K. and Florence, E.J.M. 1997. Fungal pathogens as a potential threat to tropical acacias, case study of India. In: Old, K.M., Lee, S.S. and Sharma, J.K. eds. Diseases of Tropical Acacias. Proceedings of an international workshop, Subanjeriji (South Sumatra), 28 April - 3 May 1996. CIFOR Special Publication, 70-107.

Sharma, J.K., Mohanan, C. and Florence, E.J.M. 1984. Outbreak of pink disease caused by Corticium salmonicolor in Eucalyptus grandis in Kerala, India. Tropical Pest Management 30: 253-255.

Tanaka, K. and Chalermpongse, A. 1990. Notes on forest nursery diseases in Thailand. In: Proceedings of the 3rd International Conference on Plant Protection in the Tropics Vol. IV. March 20-23, 1990. Genting Highlands. Malaysian Plant Protection Society, $161-163$.

Turnbull, J.W., Midgley, S. J. and Cossalter, C. 1998. Tropical acacias planted in Asia: an overview. In: Turnbull, J.W., Crompton, H.R. and Pinyopusarerk, K. eds. Recent Developments in Acacia Planting. Proceedings of an international workshop, Hanoi, Vietnam, October 1997. ACIAR Proceedings No. 82: 14-28.

Zulfiyah, A. and Gales, K. 1997. Diseases of tropical acacias in southern Sumatra. In: Old, K.M., Lee, S.S. and Sharma, J.K. eds. Diseases of Tropical Acacias. Proceedings of an international workshop, Subanjeriji (South Sumatra), 28 April - 3 May 1996. CIFOR Special Publication, 48-52. 


\section{Key to diseases and pathogens described in this manual}

Page number

\section{Foliage diseases}

A Infection resulting in blister-like swellings or galls

A1 Causing blister-like swellings of phyllodes

A2 Causing orange or brown-coloured galls

Atelocauda digitata

Uromycladium spp.

B Growth superficial on phyllodes

B1 Hyphae white, powdery appearance

B2 Hyphae black, perithecia may be present

Oidium sp.

Meliola spp.

B3 Algal filaments, orange on blackened

Cephaleuros virescens

C Causing necrotic spots on phyllodes, spores borne freely on phyllode surfaces

C1 Cylindrical, septate conidia

C2 Slender, tapered, septate conidia

C3 Thick walled, pigmented, septate conidia, each with an apical appendage

Cylindrocladium sp.

Cercospora and

Pseudocercospora spp.

Phaeotrichoconis crotalariae

D Causing necrotic spots on phyllodes, spores formed within flask or saucer-shaped fruiting bodies and extruded when moistened

D1 Spores hyaline, setae present on conidiomata

D2 Spores with 3 central pigmented cells and hyaline terminal cells bearing appendages

D3 Two conidial types produced, $\alpha$ (ellipsoidal) and $\beta$ (filiform)

D4 Conidia hyaline with gelatinous sheath

Colletotrichum sp.

Pestalotiopsis sp.

Phomopsis sp.

Phyllosticta sp.

\section{Stem cankers}

A White to pink mycelium superficial on bark

Corticium salmonicolor

B Mycelium not superficial, fruiting bodies embedded in the bark

B1 Black fruiting structures, some containing ovoid ascospores, several contrasting conidial types e.g. Dothiorella, Lasiodiplodia

B2 Black fruiting structures some containing sausage-shaped ascospores, others small curved conidia (Cytospora)

Valsa sp.

B3 Large, black, dome-shaped fruiting bodies, septate, pigmented, striated ascospores

Rots and decays of woody stems and roots

A Causing heart rots, a range of basidiomycete species;

e.g. Phellinus, Rigidoporus, Trametes spp.

B Causing root and butt rots, a range of basidiomycete species;

e.g. Ganoderma, Phellinus, Rigidoporus spp.

\section{Nursery diseases}

A Pre-emergence and post emergence damping-off e.g. Pythium, Fusarium spp.

B Web blight

Rhizoctonia solani 


\section{PHYLLODE RUST}

\section{Disease}

Phyllode rust, penyakit karat (Bahasa Malaysia), karat (Bahasa Indonesia)

\section{Causal organism}

Atelocauda digitata (G. Wint.) Cummins and Y. Hiratsuka syn. Uromyces digitatus Winter, Uromyces phyllodiorum (Berk. and Br.) McAlp.

\section{Host range}

A wide range of tropical and sub-tropical acacias including:

Acacia aulacocarpa, A. auriculiformis, A. crassicarpa, A. koa, A. leptocarpa, A. mearnsii, A. mangium, A. polystachya.

\section{Known distribution}

Australia (northern, eastern, south eastern and western), Papua New Guinea, China, Hawaii, Indonesia (including Java, Sumatra and Kalimantan), New Zealand. Although records have not been found for other countries the current distribution of this fungus is likely to include southern Sarawak as it was found in 1998 near Pontianak in West Kalimantan.

\section{Symptoms}

Infected phyllodes bear a range of symptoms based on the stage of the life cycle of the pathogen that is present. Rusts have complex life cycles with up to five spore types being produced, namely urediniospores, teliospores, basidiospores (which are produced on germination of the teliospores), pycniospores and aeciospores. A rust producing all spore types is designated 'macrocyclic'. Rust taxonomy is a difficult area as these fungi cannot usually be cultured except on host plants, and field pathologists often collect only one or two stages of the life cycle on infected plants. Also rusts may, during the course of evolution, lose one or more spore stages. This appears to be the case for A. digitata, in Hawaii. Hodges and Gardner (1984) and Gardner and Hodges (1985) have studied five endemic rusts, all infecting A. koa and including A. digitata. The other four species found in Hawaii may have evolved from A. digitata (Gardner 1994) and it seems possible that the form of A. digitata found most commonly associated with epidemic disease in Indonesia may have undergone similar evolutionary changes (Don Gardner, personal communication).

Figures 1-12 portray the most commonly found disease symptoms and illustrate spore types associated with phyllode rust on tropical acacias in northern Australia and South-East Asia. The spore type most diagnostic of $A$. digitata is the teliospore (Figs 12A, C, D) which bears 
fingerlike apical protrusions, giving the fungus its name. The other common spore types are urediniospores (Figs 12B, E) and aeciospores. Unfortunately these spore types are morphologically similar (both being uredinioid) and can be distinguished from each other only by specialists.

Infected phyllodes, shoot tips, petioles and even fruits of infected trees may suffer gross malformation (Figs 1-2), or more orderly cell proliferation in the form of galls or bullate (blister-like) swellings (Figs 3-5). These blisters are cinnamon brown in colour, covered with spores and smooth to the touch when young but darkening to become almost black when older (Fig. 6). Pycniospores, aeciospores and teliospores have been found on these structures. The surface of the blister is often colonised by fungal parasites (Fig. 7), which may reduce their infectivity.

The rust also produces reddish brown pustules bearing urediniospores on the surface of otherwise normal phyllodes (Figs 8-9). When the growing points of young trees are infected, the rust causes extreme swelling (hypertrophy) of the apical meristem and death of leading shoots with consequent loss of stem form (Fig. 10).

\section{Pathology}

With the exception of the detailed studies by Hodges and Gardner on A. digitata and other rust species on A. koa in Hawaii (Hodges and Gardner 1984), there is relatively little known of the pathology of this disease. Although the fungus was listed by McAlpine as Uromyces phyllodiorum in 1906, widely present on acacias in Australia, A. digitata has come to prominence as a potentially important pathogen on plantation-grown acacias only over the last few years (Old et al. 1997; Old 1998). The disease has been known on native acacia species in many parts of eastern Australia and has been previously recorded on A. auriculiformis in Java, Sumatra and South Kalimantan. The current interest has arisen from the widespread occurrence of the pathogen in the major plantation-growing areas of Sumatra and Kalimantan, especially on A. mangium, the most widely grown species. Reports of the rust on A. mangium are available from southern, central and northern Sumatra, East and South Kalimantan and most recently in West Kalimantan. The rust is able to complete its life cycle on a single host species. There is a need however for detailed studies to determine which spore and pustule types occur most commonly on different acacias, whether one or more rust species are implicated and to establish the relationship between symptom expression and the impact of rust infection on tree growth.

The disease occurs in nurseries (Fig. 11) where all stock can be affected and has to be destroyed. Failure to destroy seedlings results in the pathogen being introduced into newly planted areas. Once established in field locations, foliage of older trees bears many rust pustules that may have little effect on growth but act as sources of inoculum for young plantations. New infections appear late in the rainy season in summer rainfall areas such as northern Queensland and become more evident over the following few months as infected phyllodes become distorted and bear masses of pustules. Accounts of the progress of epidemics in young plantations in South Kalimantan indicate that severely infected foliage is shed prematurely.

In northern Australia, in native stands where different acacia species may occur together, A. digitata can be found on several species, but there is some evidence of specialisation of rust populations on particular hosts. For example in northern Queensland, where A. mangium and 
A. auriculiformis were planted in 1996 in alternate rows to encourage natural hybridisation, during severe epidemics of rust caused by A. digitata in 1997 and 1998 only A. mangium was infected (Old et al. 1999). Accounts from local foresters and pathologists in Indonesia have suggested that in Java (Santoso and Suharti 1984), Sumatra and Kalimantan, A. auriculiformis has shown symptoms of rust disease for many years. The epidemics on A. mangium appear to have been relatively recent.

\section{Impacts}

The major impacts of the disease have been, so far, in nurseries and newly planted stands of A. mangium. The disease has led to the loss of several hundreds of thousands of seedlings in some nurseries in Kalimantan, but the impact after out-planting has not been assessed. Mortality from this disease after plantation establishment seems unlikely. The loss of foliage from potentially fast-growing trees must, however, be regarded with concern. Future resources for industrial processing will depend on predictable supplies from short rotation crops, and crown retention is essential for fast growth.

\section{Control and management}

Control of the pathogen in nurseries will be readily achieved using appropriate fungicide sprays. There is no published information as yet on suitable chemicals and spraying schedules specifically for phyllode rusts on acacias but systemic fungicides such as Baycor (bitertanol) and Plantvax (oxycarboxin), effective against other rust fungi, are likely to be useful.

Seedlings or cuttings raised in nurseries where the disease is known to be present should not be transported long distances to new plantation establishment sites. There is a strong possibility that even in the absence of symptomatic plants the pathogen will be introduced into new areas on infected planting stock.

Control of the disease in plantations is more problematical. Due to the vast number of spores produced on each lesion and the efficiency of dissemination of the spores by wind, hygiene measures such as the removal and burning of infected branches or trees are unlikely to have any effect on the level of disease in young plantations.

Spraying is unlikely to be economical in plantations except for small special-purpose stands, e.g. clone banks or hybridisation trials. Provenance or clonal trials or seed production stands should not be sprayed as the presence of highly variable germ plasm in such stands, in the event of a rust outbreak, gives an opportunity to select disease resistant trees.

At this stage of our knowledge of the disease in acacia plantations it is not clear whether A. digitata will have sufficient impact on stem growth to warrant a major effort in breeding for resistance. Experience with other rust diseases of major plantation species (e.g. poplar rusts) suggests that clonal forestry, in the absence of selection for resistant clones, could result in highly susceptible populations of trees. Preliminary data suggest that large differences in susceptibility to rust occur at the species, provenance and family level (Old et al. 1999) and inclusion of resistant traits in acacia improvement programs will be useful. 


\section{References}

Gardner, D.E. 1994. The native rust fungi of Hawaii. Canadian Journal of Botany 72: 976-989.

Gardner, D. E. and Hodges, C.S. 1985. Spore surface morphology of Hawaiian Acacia rust fungi. Mycologia 77: 575-586.

Hadi, S. and Nuhamara, S.T. 1997. Diseases of species and provenances of acacias in West and South Kalimantan, Indonesia. In: Old, K.M., Lee, S.S. and Sharma, J.K. eds. Diseases of Tropical Acacias. Proceedings of an international workshop, Subanjeriji (South Sumatra), 28 April - 3 May 1996. CIFOR Special Publication, 23-47.

Hodges, C.S. and Gardner, D.E. 1984. Hawaiian forest fungi. IV. Rusts on endemic Acacia species. Mycologia 76: 332-349.

McAlpine, D. 1906. The Rusts of Australia. Government Printer, Melbourne, Australia, $349 \mathrm{p}$.

Old, K.M., Hood, I. A. and Yuan, Z.Q. 1997. Diseases of tropical acacias in northern Queensland. In: Old, K.M., Lee, S.S. and Sharma, J.K. eds. Diseases of Tropical Acacias. Proceedings of an international workshop, Subanjeriji (South Sumatra), 28 April - 3 May 1996. CIFOR Special Publication, 1-22.

Old, K.M. 1998. Diseases of tropical acacias. In: Turnbull, J.W., Crompton, H.R. and Pinyopusarerk, K. eds. Recent Developments in Acacia Planting. Proceedings of an international workshop, Hanoi, Vietnam, October 1997. ACIAR Proceedings No. 82: 224-233.

Old, K.M., Butcher, P.A., Harwood, C.E. and Ivory, M.H. 1999. Atelocauda digitata, a rust disease of tropical plantation acacias. Proceedings of the 12th Biennial Conference of the Australasian Plant Pathology Society, Canberra 1999, 249.

Santoso, E. and Suharti, M. 1984. Studi morfologis dan anatomis Cendawan Karat yang menyerang tananaman Acacia auriculiformis A. Cunn. Laporan, Pusat Penelitian dan Pengembangan Hutan, Indonesia. 441, 15 p. 

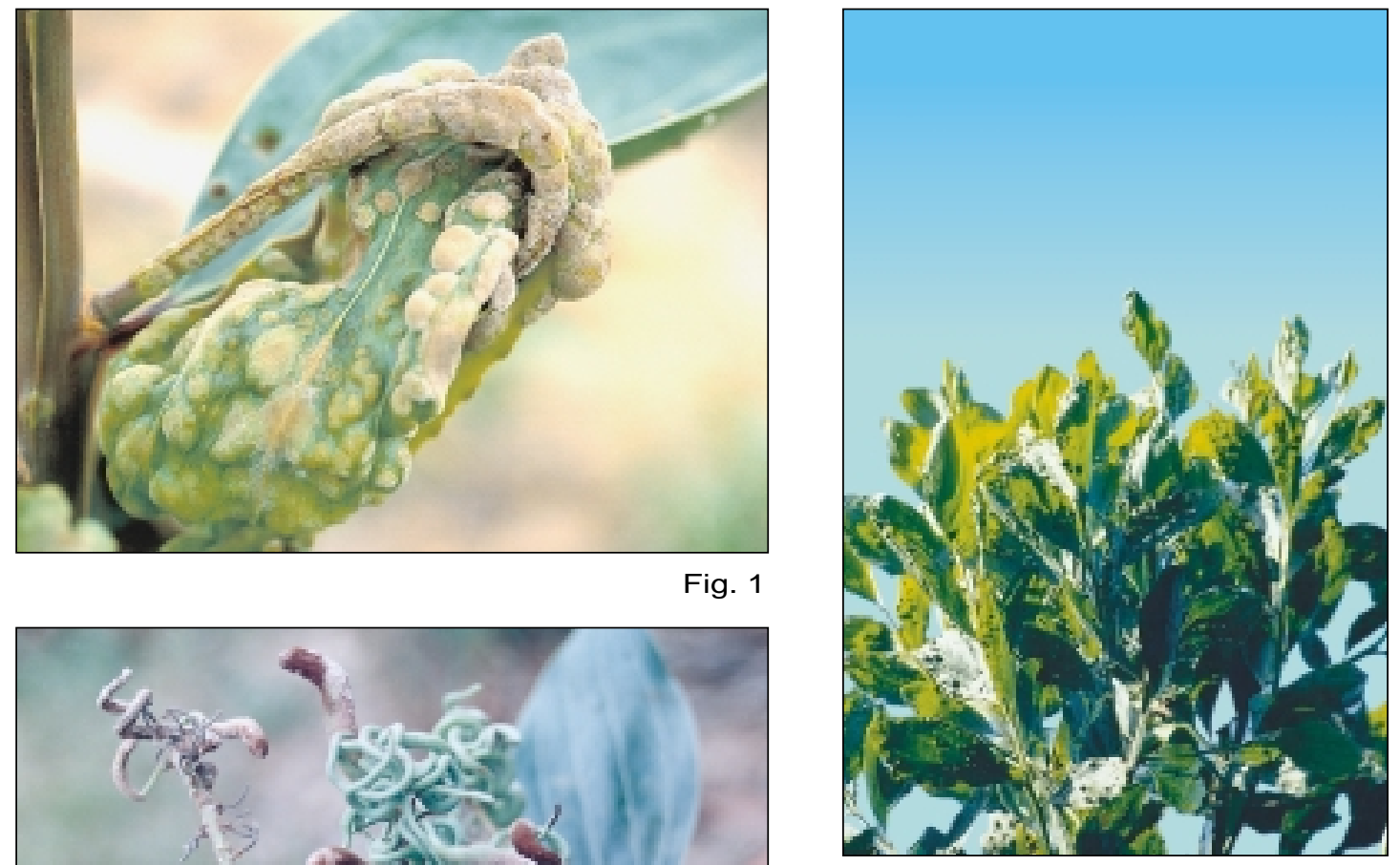

Fig. 4

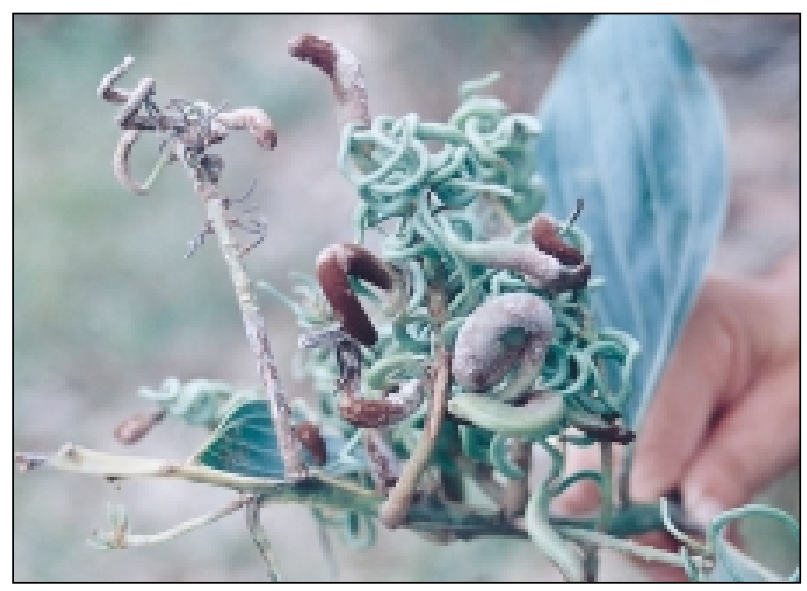

Fig. 2

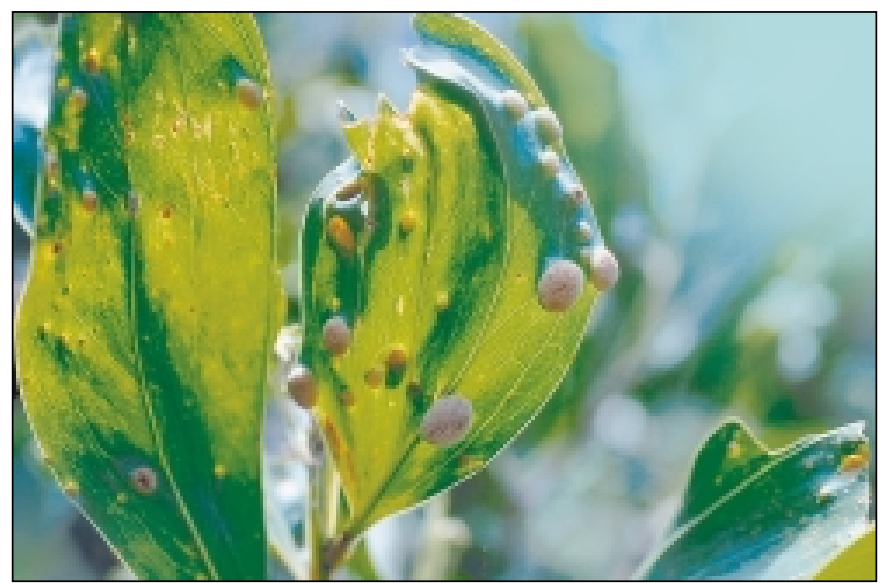

Fig. 3

Fig. 1 Petiole and lamina of Acacia mangium phyllode, malformed by Atelocauda digitata infection (West Kalimantan)

Fig. 2 Malformation of seed pods resulting from rust infection (Sumatra)

Fig. 3 Bullate swellings bearing rust spores on A. mangium phyllodes (north Queensland, Australia) Fig. 4 Crown of sapling A. mangium heavily infected by rust (South Kalimantan) 


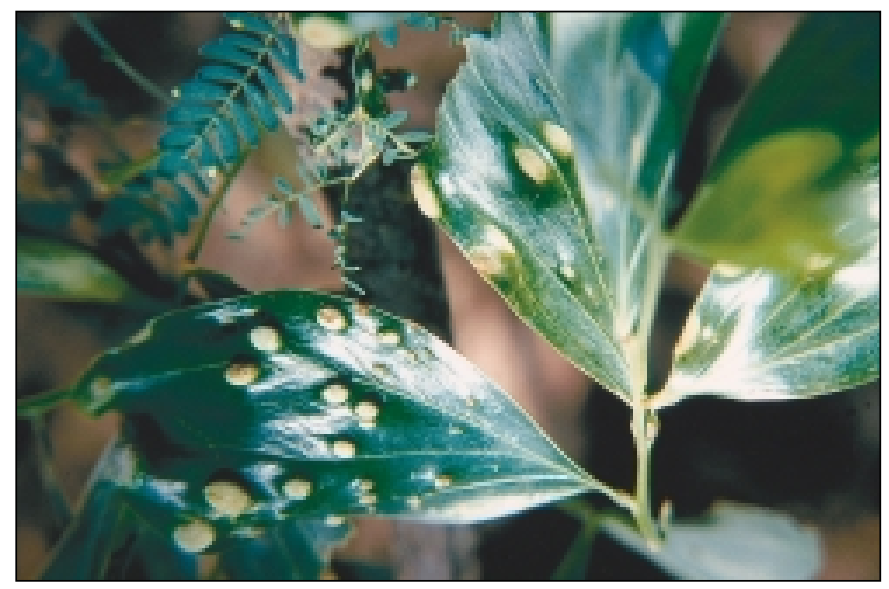

Fig. 5

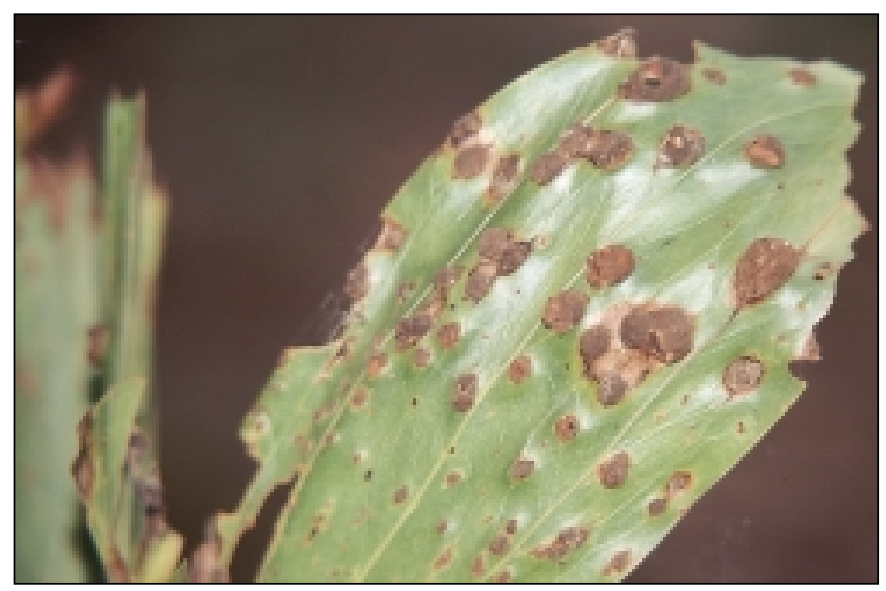

Fig. 6

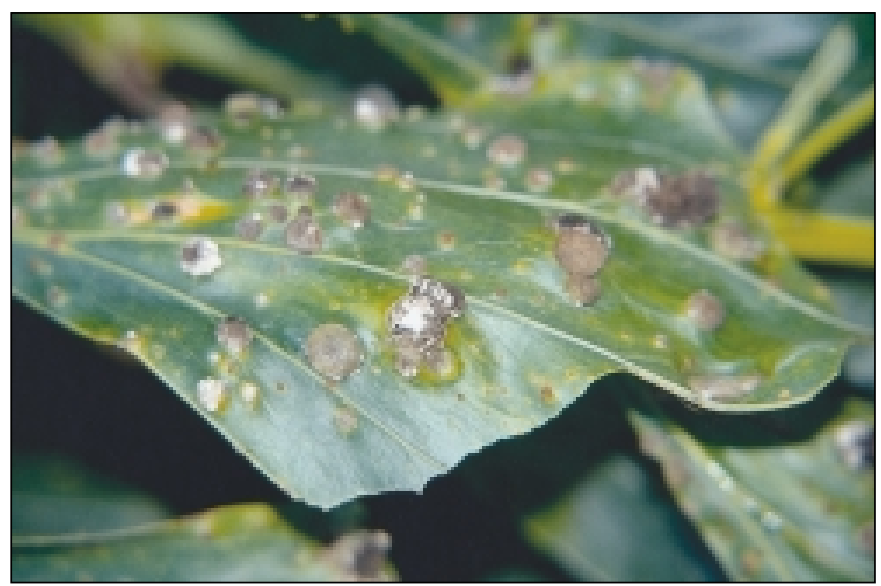

Fig. 7

Fig. 5 Newly infected Acacia mangium seedlings with immature lesions (South Kalimantan) Fig. 6 Mature, bullate lesions on A. mangium, teliospores are present on surfaces (north Queensland, Australia)

Fig. 7 Old lesions colonised by hyperparasitic fungi (South Kalimantan) 

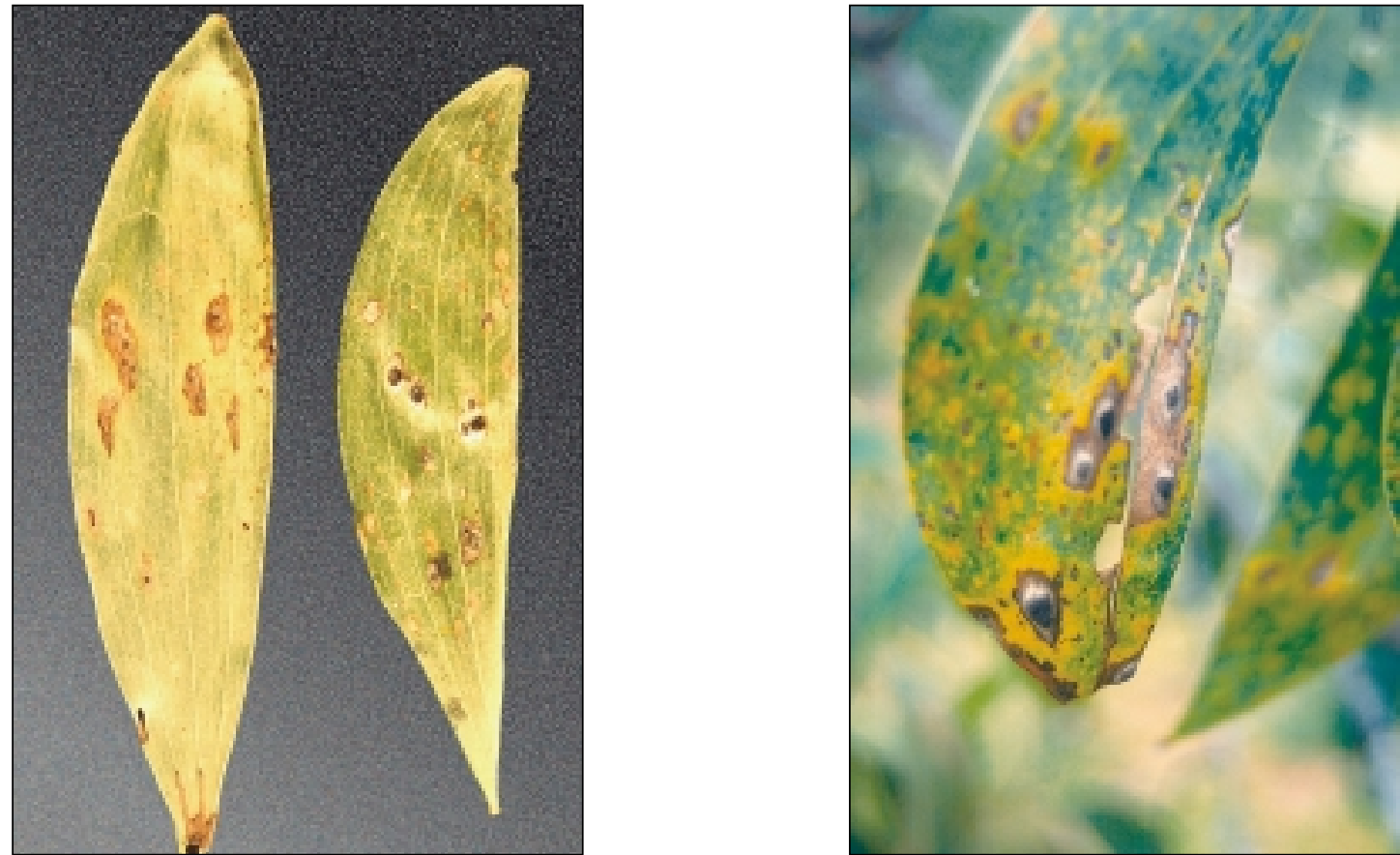

Fig. 8

Fig. 9
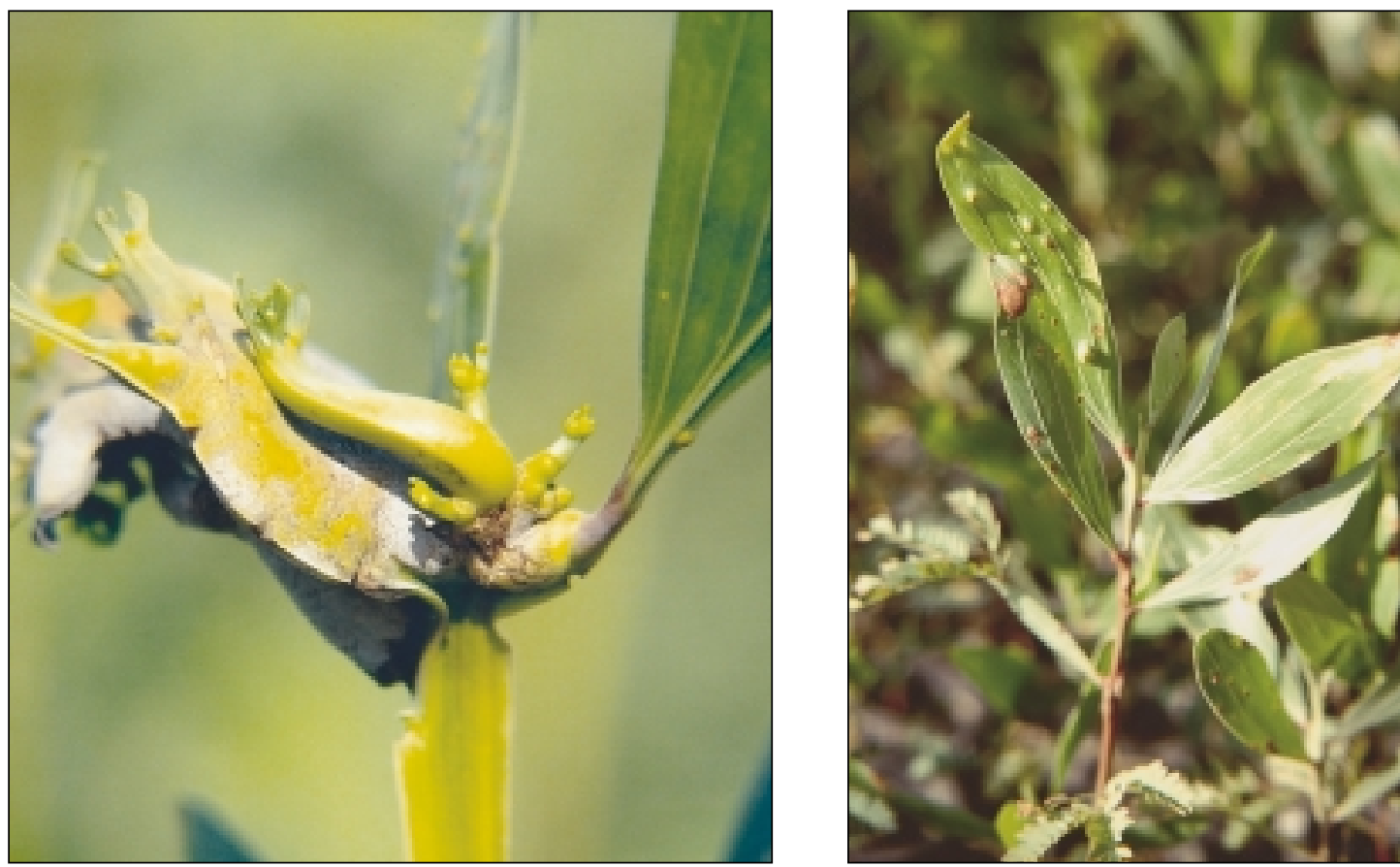

Fig. 10

Fig. 11

Figs 8-9 Phyllodes of Acacia auriculiformis (Fig. 8) and A. crassicarpa (Fig. 9) from native stands in north Queensland. Dark brown bullate lesions bear teliospores of Atelocauda digitata; orange lesions bear urediniospores of the rust

Fig. 10 Grossly malformed apical meristem of A. mangium sapling (South Kalimantan)

Fig. 11 Seedlings heavily infected by $A$. digitata (South Kalimantan) 

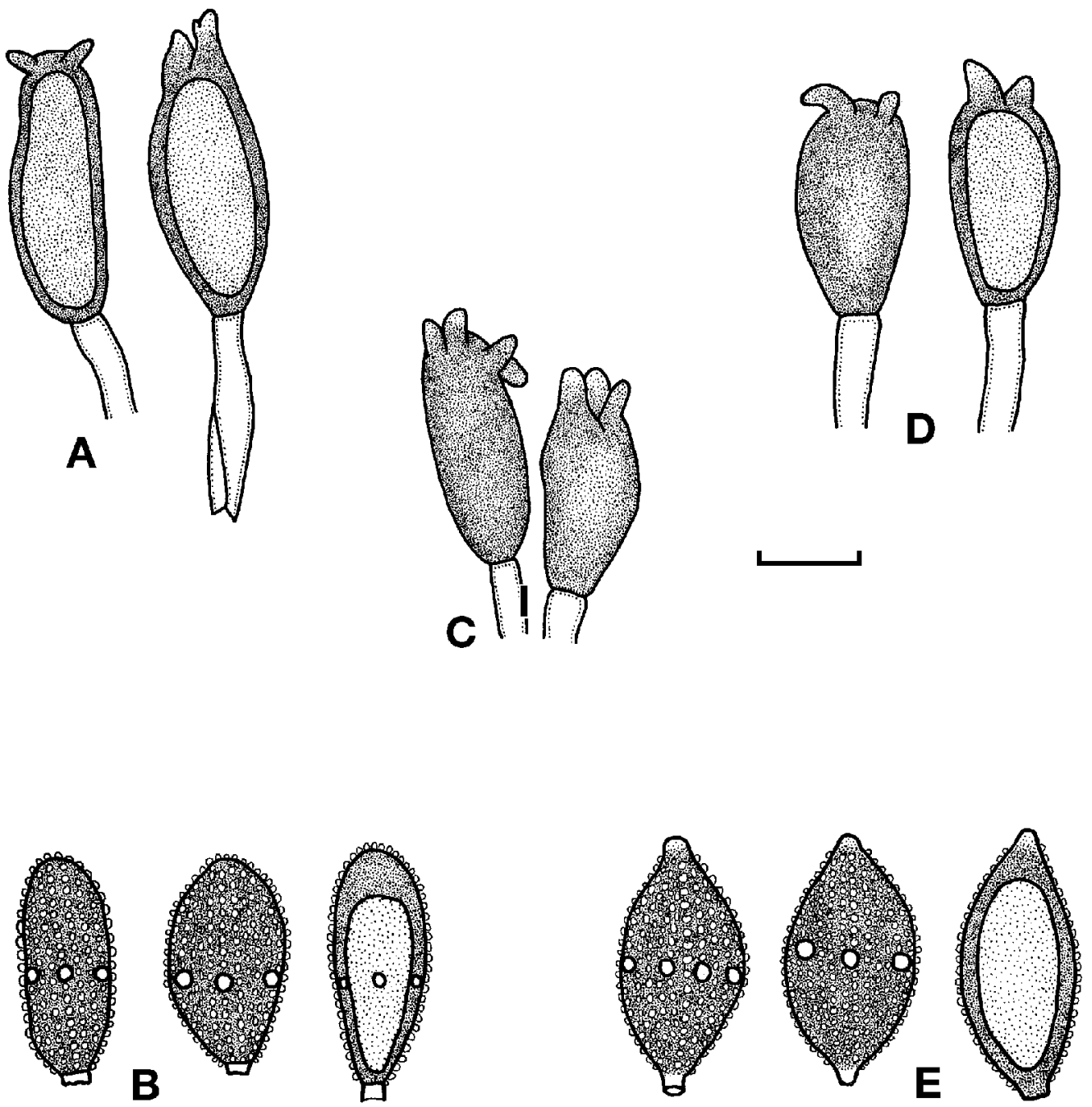

Fig. 12

Fig. 12 Atelocauda digitata

A, B. Teliospores and urediniospores on Acacia aulacocarpa

C. Teliospores on A. auriculiformis (left) and A. mangium (right)

D. Teliospores on A. auriculiformis

E. Urediniospores on A. crassicarpa

(Bar $=20 \mu \mathrm{m}$ for $\mathrm{A}-\mathrm{E})$ 


\section{GALL RUSTS}

\section{Disease}

Gall rust, karat puru (Bahasa Malaysia)

\section{Causal organisms}

Uromycladium tepperianum (Sacc.) McAlpine, Uromycladium notabile (Ludw.) McAlpine

\section{Host range}

In Australia these rusts occur on a very wide range of Acacia spp. (Figs 13, 15). A survey of publications showed 57 species of acacias being recorded as hosts of $U$. tepperianum across Australia (McAlpine 1906; Warcup and Talbot 1981). A survey of the host range of the fungus in the south-west of Western Australia yielded a further 50 records on new hosts (Gathe 1971). The fungus also infects Paraserianthes lophantha ssp. lophantha (Willd.) Nielson in Australia and $P$. lophantha ssp. montana (Junghuhn.) Nielsen in Java (Fig. 14). U. notabile is extremely common in southern Australia on a wide range of hosts in native forests and woodlands, and can be found in plantations of bipinnate acacias such as A. mearnsii and A. dealbata. Morris (1987) showed that native African Acacia and Paraserianthes spp. are not susceptible to $U$. tepperianum. Due to the similarity of galls produced by these fungi, some collections identified as $U$. tepperianum have been found to be $U$. notabile. For example, Morris et al. (1988) indicated that all collections of gall rusts on A. mearnsii have been $U$. notabile.

\section{Known distribution}

Both of these rust fungi are widely distributed in Australia on a great number of Acacia spp. and have spread to New Zealand. In that country establishment of $U$. notabile on $A$. mearnsii (referred to in reports as A. decurrens) led to the abandonment and the felling of a 1800 ha plantation resource planned as the basis for a tannin industry (Dick 1985). U. tepperianum has been reported from only the North Island of New Zealand on A. paradoxa, A. ulicifolia and A. verticillata. Galls typical of Uromycladium infections were observed on A. auriculiformis in Vanuatu (Old, unpublished information) although the species was not determined. $U$. tepperianum occurs in Java on P. lophantha ssp. montana (McAlpine 1906) and in Papua New Guinea on Albizia (Paraserianthes) spp. (Shaw 1984). Undetermined species of Uromycladium have also been reported on Paraserianthes falcataria in Sabah (Anon. 1993) and the Philippines (de Guzman et al. 1991). In 1987, the South African government approved the release of inoculum of $U$. tepperianum in an attempt to achieve biological control of A. saligna, an introduced Australian species that has become a major weed problem. The pathogen is now well established in South Africa. 


\section{Symptoms}

A range of symptoms is produced by infection with Uromycladium spp. of which the most characteristic is the formation of reddish-brown, globose galls several centimetres in diameter which occur on stems and shoots of the trees (Figs 13, 15). The surfaces of mature galls become covered with cinnamon-coloured spores. Inflorescences, phyllodes, fruits and shoot tips can also be infected with smaller galls causing gross malformation (Gathe 1971). When fresh, the galls are covered with powdery masses of spores. Older galls become reddish brown and eventually blackened and are commonly invaded by tunneling insects, sometimes resulting in misidentification as insect-induced galls. Susceptible trees may bear thousands of branch galls (Fig. 15) which affect the form of the tree due to repeated branching. Foliage terminal to the infections dies due to girdling of the shoot and severely infected trees may die.

\section{Pathology}

Spores are formed on the surface of the galls of both Uromycladium spp. U. notabile produces orange urediniospores on fresh galls (Fig. 13) followed by darker chocolate-brown teliospores. U. tepperianum, however, forms teliospores only. The rusts can be distinguished by the surface ornamentation of their teliospores (McAlpine 1906). Teliospores of U. tepperianum bear converging striations (Fig. 16), but these are absent from teliospores of

$U$. notabile. Infective spores are wind blown from one host plant to the next and can infect virtually any plant part except older stems with thick bark. The host reacts to the presence of the pathogen by producing the characteristic gall tissue. The rust completes the whole life cycle on a single tree, and during the growing season a gall of moderate size will produce many millions of spores that can infect neighbouring trees or disperse the fungus over long distances.

\section{Impacts}

Impacts of these two pathogens on susceptible hosts can be severe, with stem and shoot malformation and, in extreme cases, tree death. The selection of $U$. tepperianum as a biocontrol for A. saligna in South Africa reflects its capacity to severely damage tree health (De Selincourt 1992). Both pathogens can be readily found on trees in native stands in Australia and individual trees can be severely affected (Fig. 15). Reported impacts on plantation-grown acacias are limited to temperate species, e.g. A. mearnsii and A. dealbata, rather than the four tropical plantation species that are the focus of this manual. The surveys that produced the main body of information for this manual produced only one report, from northern Queensland, of U. tepperianum on A. flavescens (Old et al. 1997). Despite the ease with which gall rust caused by Uromycladium is detected, surveys in Indonesia, Thailand, India and Malaysia during 1995 did not record this disease.

\section{Control and management}

There is no control known for gall rust of acacias and no selection programs for resistance have so far been warranted. It seems likely that increasing interest in bipinnate temperate species in southern Australia will result in tree improvement programs developing over the next decade. Experience with rust diseases of other tree genera indicates that major differences in resistance will exist at the species, provenance and family levels. 


\section{References}

Anonymous. 1993. SFI/JTF Annual Report 1993. Sabah Forest Industries. Kota Kinabalu.

De Selincourt, K. 1992. South Africa's other bush war. New Scientist 1808: 36-39.

Dick, M. 1985. Uromycladium rusts of Acacia. Forest Pathology in New Zealand No. 15,8 p.

Gathe, J. 1971. Host range and symptoms in Western Australia of the gall rust, Uromycladium tepperianum. Journal of the Royal Society of Western Australia 54: 114-118.

Guzman E.D. de, Militante, E.P. and Lucero, R. 1991. Forest nursery diseases and insects in the Philippines. In: Sutherland, J.R. and Glover, S.G. eds. Proceedings of the First Meeting of IUFRO Working Party S2.07-09. Victoria, British Columbia, Canada, 22-30 August 1990. Forestry Canada, Pacific Forestry Centre, Information Report BC-X-331: 101-104.

McAlpine, D. 1906. The Rusts of Australia. Government Printer, Melbourne, Australia, $349 \mathrm{p}$.

Morris, M.J. 1987. Biology of the Acacia gall rust, Uromycladium tepperianum. Plant Pathology 36: 100-106.

Morris, M.J., Wingfield, M.J. and Walker, J. 1988. First record of a rust on Acacia mearnsii in Southern Africa. Transactions of the British Mycological Society 90: 325-327.

Old. K.M., Hood, I.A. and Yuan, Z.Q. 1997. Diseases of tropical acacias in northern Queensland. In: Old, K.M., Lee, S.S. and Sharma, J.K. eds. Diseases of Tropical Acacias. Proceedings of an international workshop, Subanjeriji (South Sumatra), 28 April - 3 May 1996. CIFOR Special Publication, 1-22.

Shaw, D.E. 1984. Microorganisms in Papua New Guinea. Dept of Primary Industries, Port Moresby, Papua New Guinea. Research Bulletin No. 33, 344 p.

Warcup, J.H. and Talbot, P.H.B. 1981. Host-pathogen Index of Plant Diseases in South Australia. Waite Agricultural Research Institute Adelaide, Australia, 114 p. 

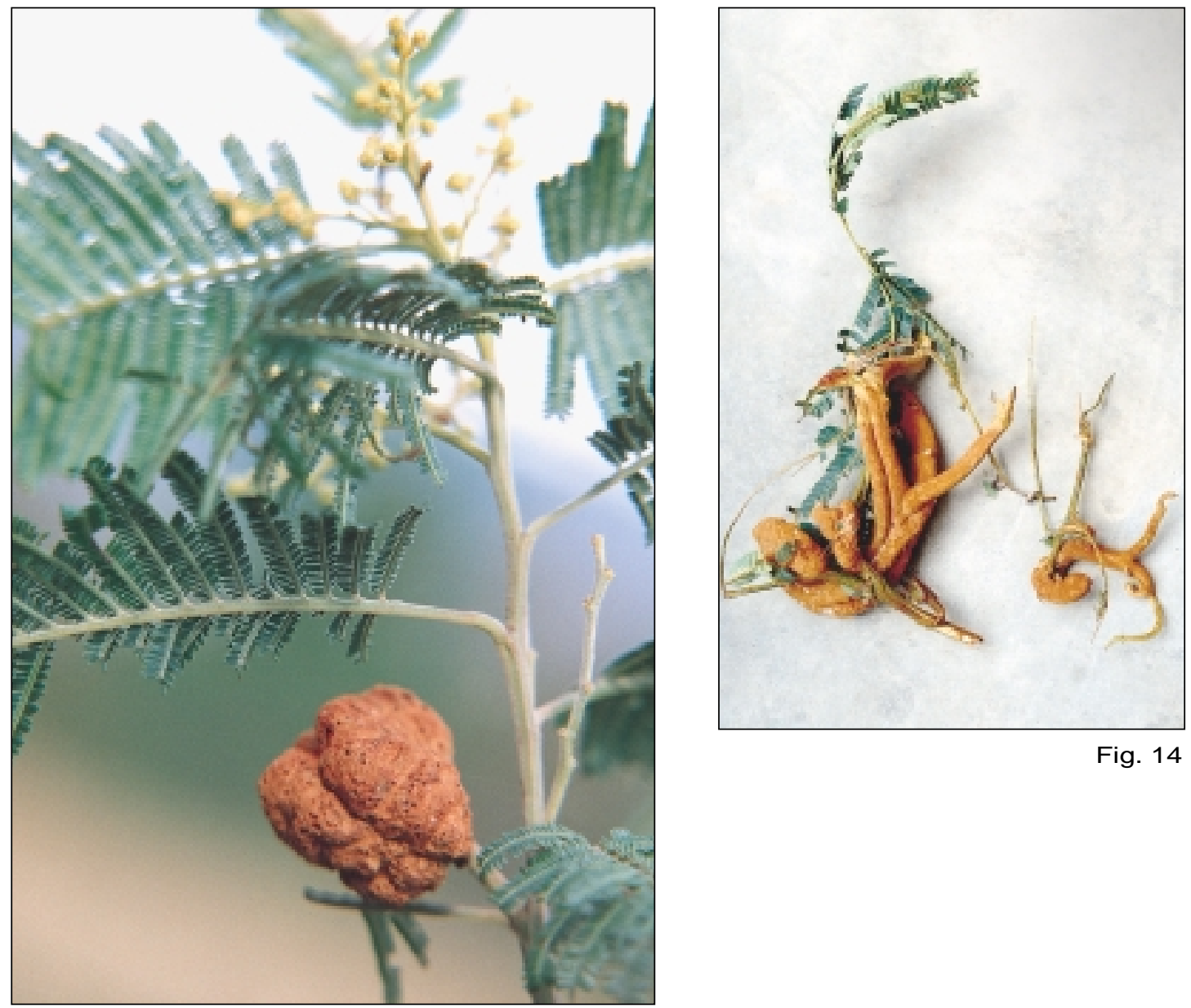

Fig. 14

Fig. 13

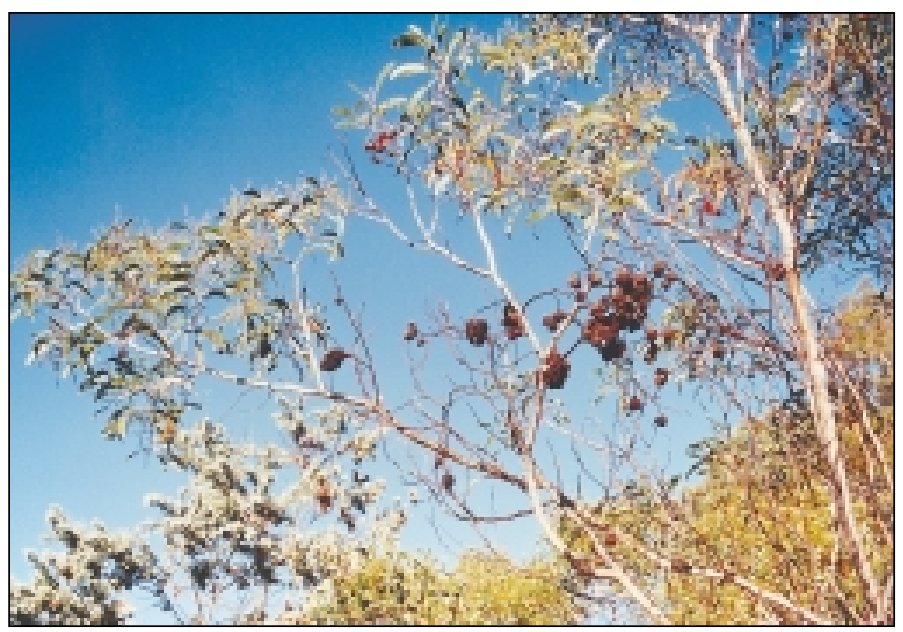

Fig. 15

Fig. 13 Gall on Acacia mearnsii caused by Uromycladium notabile (New South Wales, Australia) Fig. 14 Shoots of Paraserianthes falcataria, much distorted from infection by $U$. tepperianum (Malaysia)

Fig. 15 Acacia pycnantha with a heavy crop of $U$. notabile galls (New South Wales, Australia) 


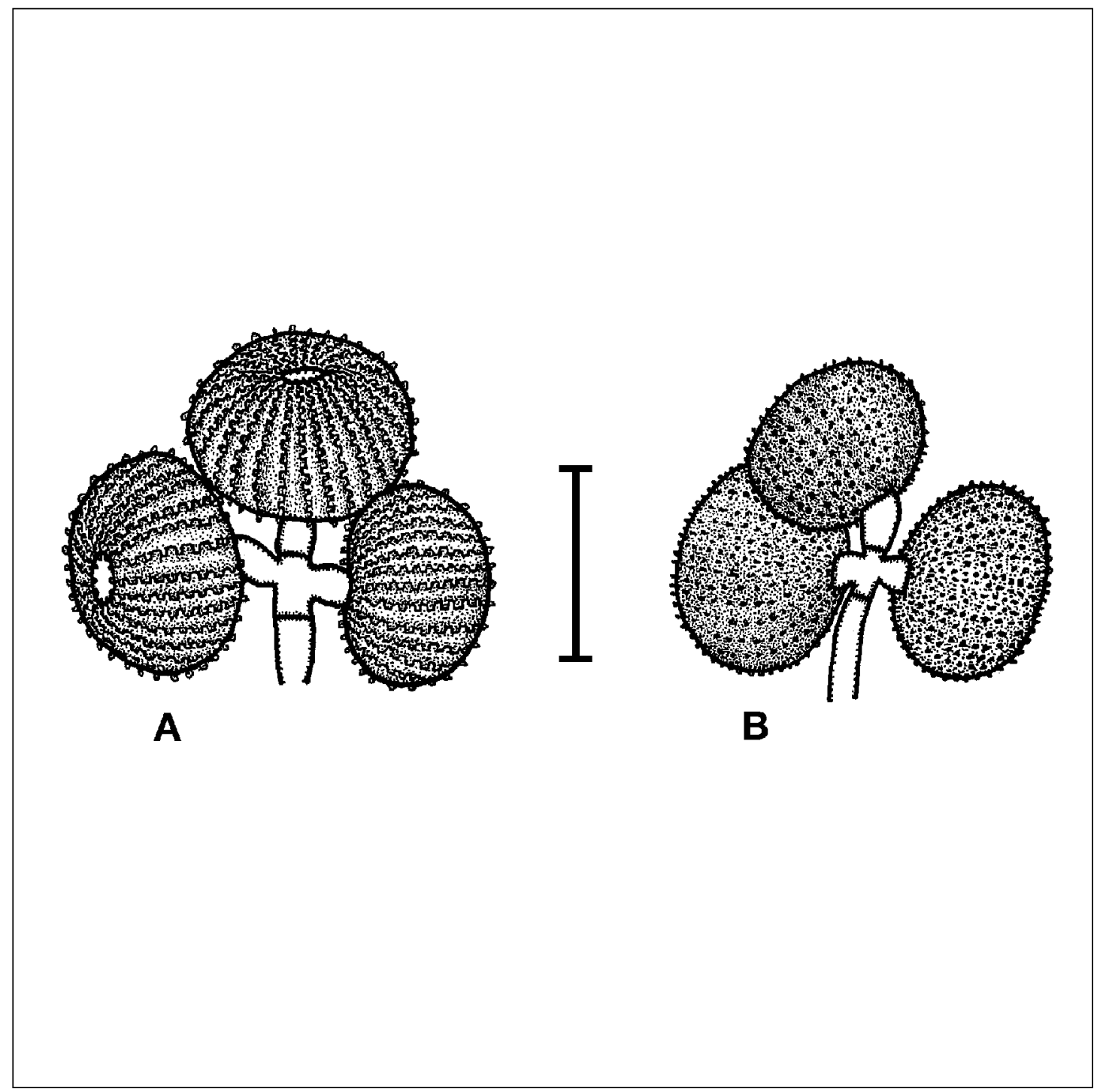

Fig. 16

Fig. 16 Uromycladium spp.

A. Teliospores of $U$. tepperianum on Acacia sp.

B. Teliospores of $U$. notabile on A. mearnsii

$(\mathrm{Bar}=20 \mu \mathrm{m}$ for $\mathrm{A}$ and $\mathrm{B}$ ) 


\section{POWDERY MILDEW}

\section{Disease}

Powdery mildew, kulapuk debu (Bahasa Malaysia), penyakit tepung (Bahasa Indonesia)

\section{Causal organism}

Oidium spp. are mitosporic fungi (the species of Oidium on these four tropical acacias and its perfect state have not yet been identified), indeed it is possible that more than one species is involved. A teleomorph, Erysiphe acaciae S. Blumer, has been observed on Acacia catechu in India (Bakshi 1976).

\section{Host range}

Oidium spp. are obligate parasites which attack many hosts. On acacias, powdery mildew is found on the phyllodes, mainly of plants in the nursery and also in the lower crown of young trees in the field. Species of Oidium have been found on A. aulacocarpa (Boa and Lenné 1994), A. auriculiformis (Tanaka and Chalermpongse 1990), A. crassicarpa (Old et al. 1997), and A. mangium (Anonymous 1983; Maziah 1990; Tanaka and Chalermpongse 1990; Boa and Lenné 1994) and on many other acacia species grown in nurseries.

\section{Known distribution}

The disease has been reported on acacias in Australia, parts of Africa, China, Hawaii, India, Indonesia, the Philippines, Malaysia and Thailand. Gibson (1975) reported four powdery mildews of acacias but these did not include those on A. aulacocarpa, A. auriculiformis, A. crassicarpa and A. mangium.

\section{Symptoms}

Early symptoms appear as discrete, cobweb-like to powdery white patches of hyphae and spores on the primary, juvenile, pinnate leaves (Fig. 17). As infection progresses, these patches increase in size and coalesce to form bigger patches, spreading to the secondary leaves or phyllodes (Fig. 18), sometimes resulting in defoliation. The upper surfaces of heavily infected foliage become coated with a mat of superficial hyphae and spores, with the foliage looking as though dusted with powder, hence the name 'powdery mildew'. The symptoms can sometimes be mistaken for road dust, especially on trees planted near dirt roads. The infection leaves yellow blotches on the surface of the foliage.

\section{Pathology}

Spores of the fungus germinate on the surfaces of the phyllodes, producing germ tubes which penetrate the walls of the leaf epidermal cells. The fungus forms absorbing structures known 
as haustoria through which it obtains nourishment from the host cells. The fungus proliferates over the phyllode surfaces, producing abundant conidia (Fig. 19). The spores, which are produced successively on specialised hyphae arising from the superficial mycelium (Fig. 20), are dispersed by wind to other susceptible hosts, initiating new infections. The perfect stage of the fungus causing powdery mildew of acacias has not been conclusively identified.

\section{Impacts}

In well-managed nurseries with good hygiene, this disease is generally not considered of great importance. However, under conducive conditions heavy infestation may result in premature loss of both the juvenile leaves and phyllodes, thus inhibiting photosynthesis and retarding subsequent growth. Plants are rarely killed by the disease but in one instance in Thailand where $90 \%-100 \%$ infection of $A$. auriculiformis seedlings was recorded, about $75 \%$ of the seedlings perished (Tanaka and Chalermpongse 1990). Trees appear to develop resistance with age as the disease is seldom observed in the field on trees more than two years old.

\section{Control and management}

Intensively cultivated plants and those growing under shady conditions are usually more susceptible to the disease. Early recognition and prompt removal of infected plants are important in preventing disease spread, and fallen leaves should be destroyed to reduce inoculum potential.

Chemical treatments are seldom necessary unless damage is severe. Sulphur dusting with a powder duster or application of fungicides such as benomyl, chlorothalonil, triademefon, maneb and zineb gives effective control.

Josiah and Allen-Reid (1991) indicated that the disease can be controlled by placing diseased seedlings in direct sunlight for an extended period.

\section{References}

Anonymous. 1983. Mangium and other acacias for the humid tropics. Innovations in Tropical Reforestation. National Academy Press, Washington D.C., 63 p.

Bakshi, B.K. 1976. Forest Pathology: Principles and Practices in Forestry. Controller of Publications, Delhi, 400 p.

Boa, E. and Lenné, J. 1994. Diseases of Nitrogen Fixing Trees in Developing Countries: An Annotated List. Natural Resources Institute, Overseas Development Administration, $82 \mathrm{p}$.

Gibson, I.A.S. 1975. Diseases of Forest Trees Widely Planted as Exotics in the Tropics and Southern Hemisphere. Part 1. Important members of the Myrtaceae, Leguminosae, Verbenaceae and Meliaceae. Commonwealth Mycological Institute, CAB, U.K., 51 p. 
Josiah, S.J. and Allen-Reid, D. 1991. Important nursery insects and diseases in Haiti and their management. In: Sutherland, J.R. and Glover, S.G. eds. Proceedings of the First Meeting of IUFRO Working Party S2.07-09, Victoria, British Columbia, Canada, 22-30 August 1990. Forestry Canada, Pacific Forestry Centre, Information Report BC-X-331: 51-59.

Maziah, Z. 1990. Diseases of forest plantation species in Peninsular Malaysia.

In: Hutacharern, C., MacDicken, K.G., Ivory, M.H. and Nair, K.S.S. eds. Pests and Diseases of Forest Plantations in the Asia-Pacific Region. RAPA Publication 1990/9. FAO-RAPA, Bangkok, 94-99.

Old, K.M., Hood, I.A. and Yuan, Z.Q. 1997. Diseases of tropical acacias in northern Queensland. In: Old, K.M., Lee, S.S. and Sharma, J.K. eds. Diseases of Tropical Acacias. Proceedings of an international workshop, Subanjeriji (South Sumatra), 28 April - 3 May 1996. CIFOR Special Publication, 1-22.

Tanaka, K. and Chalermpongse, A. 1990. Notes on forest nursery diseases in Thailand. In: Proceedings of the 3rd International Conference on Plant Protection in the Tropics Vol. IV. 20-23 March 1990. Genting Highlands. Malaysian Plant Protection Society, 161-163. 


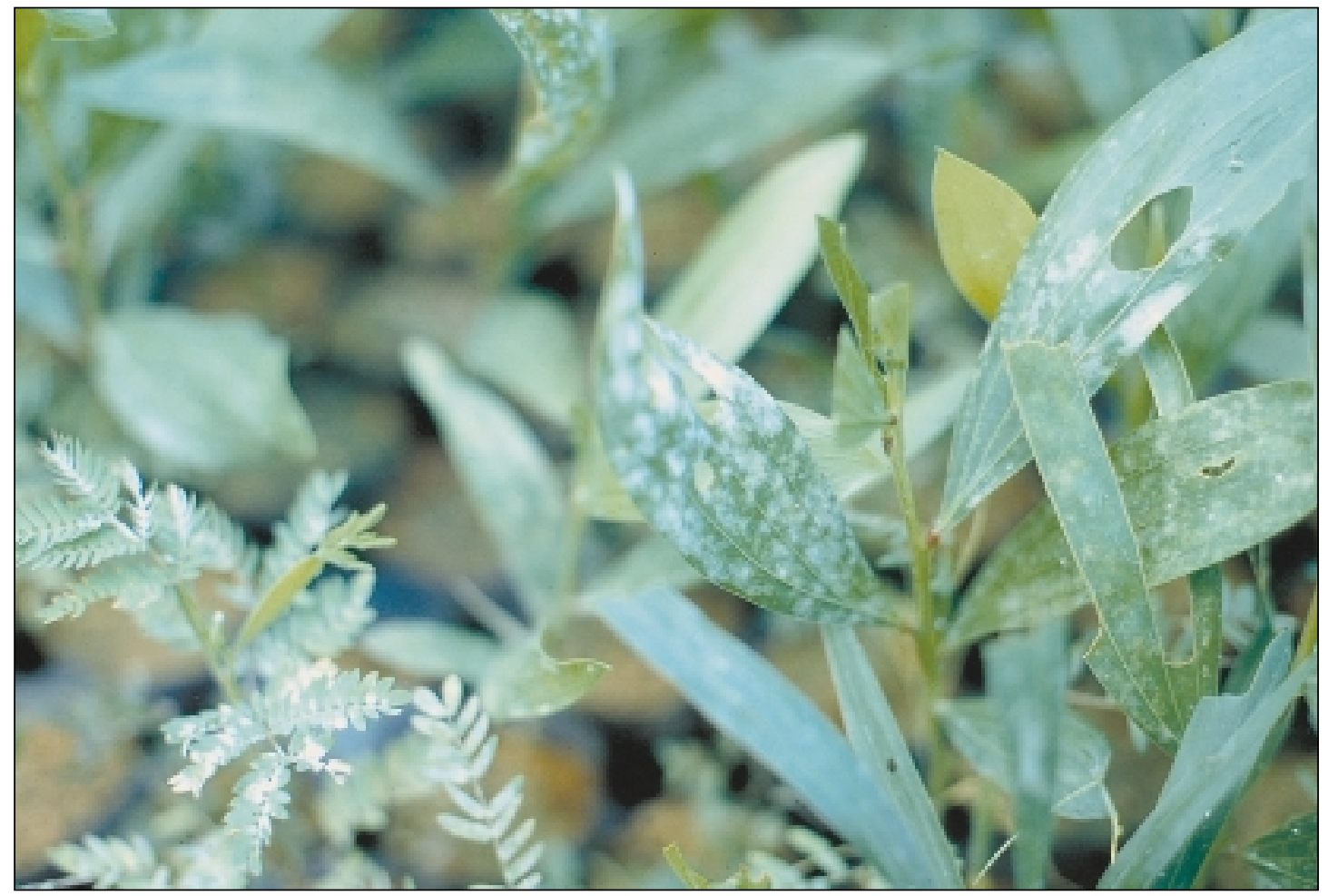

Fig. 17

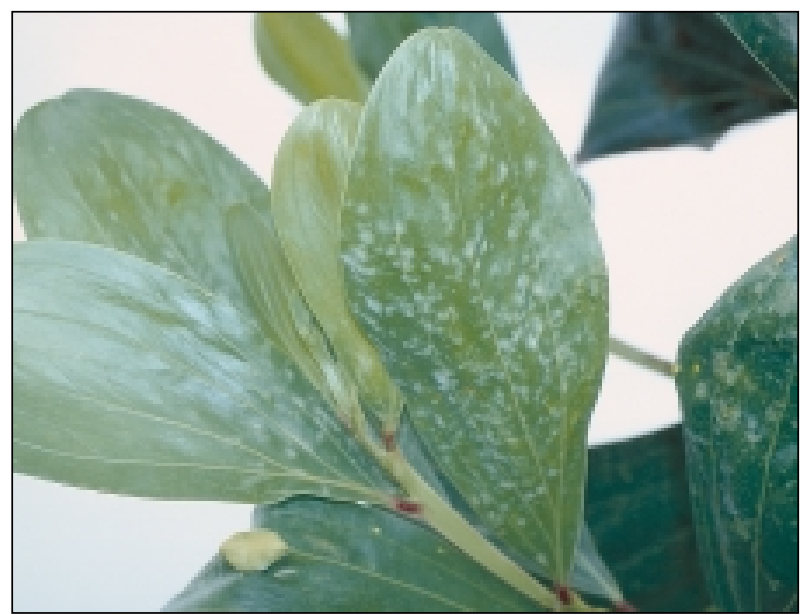

Fig. 18

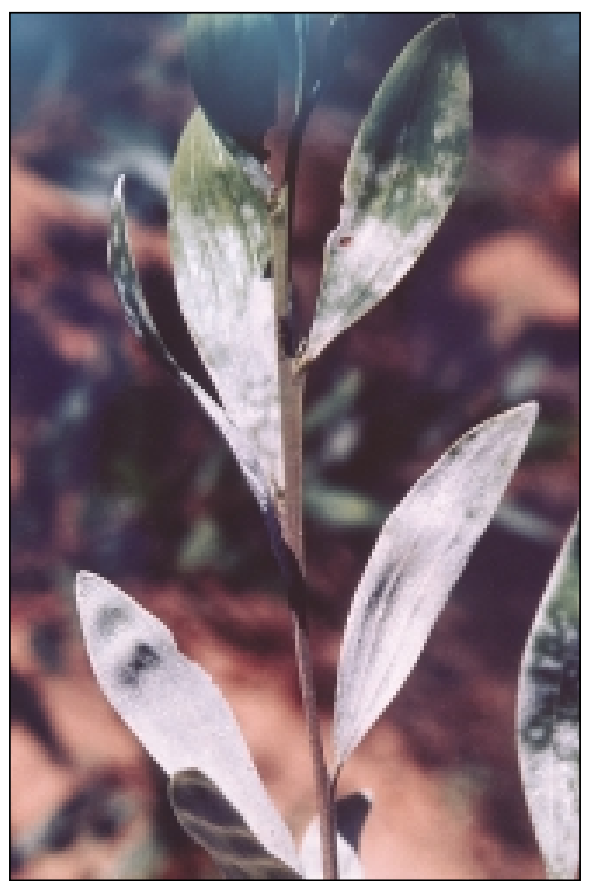

Fig. 19

Fig. 17 Powdery mildew on Acacia mangium seedlings (Malaysia)

Fig. 18 Powdery mildew on A. mangium saplings (South Sumatra)

Fig. 19 A. auriculiformis seedling affected by powdery mildew (Kerala, India) 


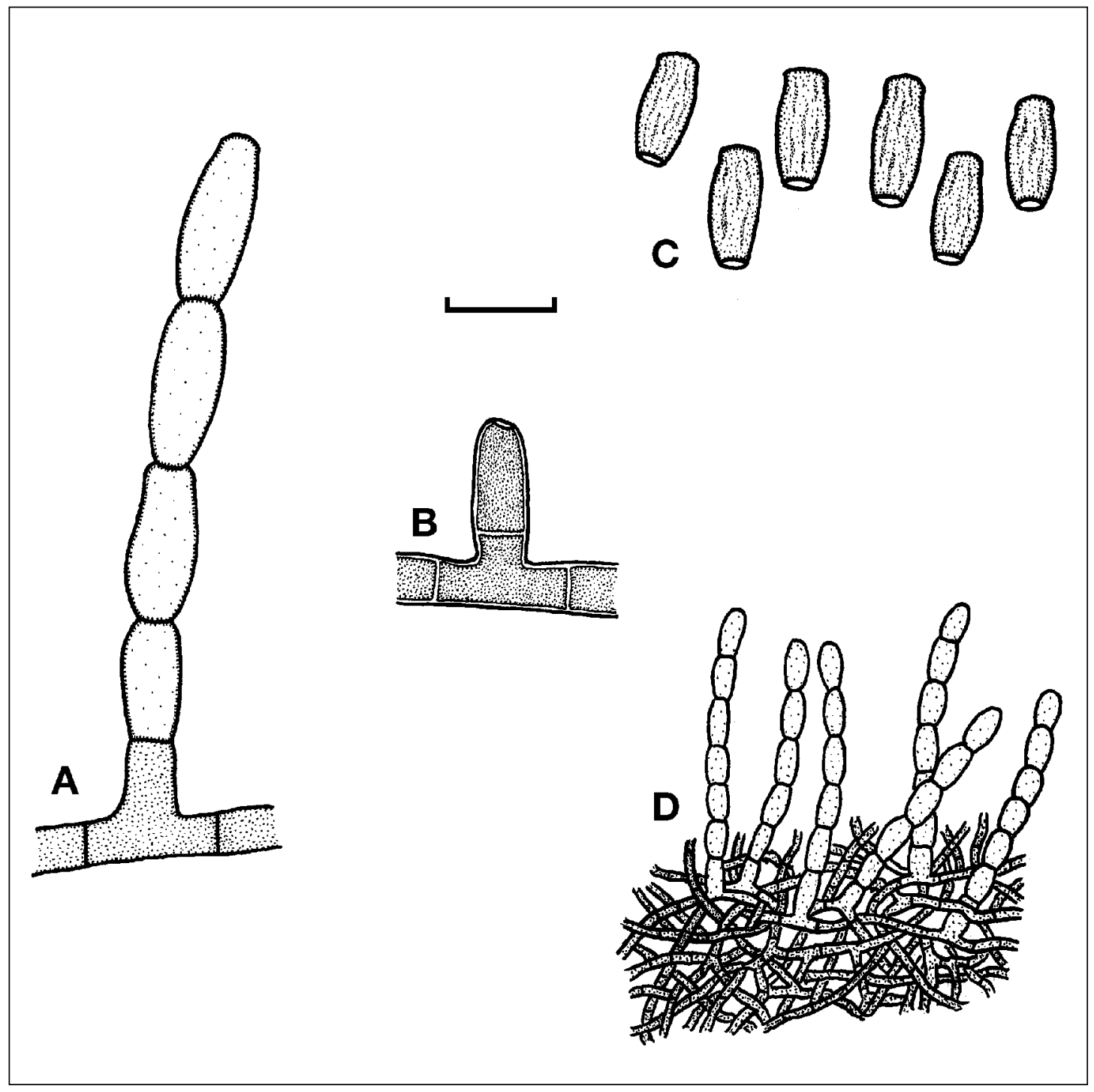

Fig. 20

Fig. 20

Oidium sp. on Acacia mangium
A. Conidiophore and conidia in chains
B. Detail of conidiophore
C. Conidia
D. Habit of mycelium and conidiophores on leaf surface
$(\mathrm{Bar}=20 \mu \mathrm{m}$ for $\mathrm{A}-\mathrm{C} ;=50 \mu \mathrm{m}$ for $\mathrm{D})$ 


\section{BLACK MILDEW}

\section{Disease}

Black mildew, penyakit tepung gelap (Bahasa Indonesia)

\section{Causal organisms}

The fungi causing black mildew, Meliola spp., belong to the family Meliolaceae, order Meliolales of the Ascomycota. The black mildews are often confused with the common sooty moulds which are superficial epiphytic saprophytes. The Meliolales, however, are obligate parasites which produce a variety of structures that penetrate host cells.

\section{Host range and distribution}

Species of Meliola are found on leaves and stems of a wide range of hosts in the tropics. Black mildew is common on acacias but there has been little study of the causal organisms. M. brisbanensis has been reported on Acacia auriculiformis and A. mangium in Queensland (Old et al. 1997) and on A. dealbata in Malaysia (Singh 1980). Ivory (1988) listed M. adenanphererae Cit. \& Hansf. on A. auriculiformis in Java (unpublished report). Other species of Meliola found on acacias have yet to be identified.

\section{Symptoms}

The fungus forms black, radiate, velvety colonies on the surface of the phyllodes (Figs 21-22). In cases of heavy infestation, the entire phyllode surface may be covered by the fungus. The infection is usually more frequent on the upper than on the lower phyllode surface. Sometimes young stems and twigs can also be infected. Minute spherical fruiting bodies develop on the fungal thallus (Fig. 23). In M. brisbanensis these ascocarps have pigmented walls bearing setae and contain sac-shaped asci containing four pigmented ascospores (Fig. 24).

\section{Pathology}

No in-depth studies have been carried out on the black mildew of acacias. Ascospores of $M$. mangiferae have frequently been observed to germinate on mango leaves but no success has been achieved with artificial inoculation. The close association of Meliola spp. with scale insects and mealybugs suggests that the honeydew excreted by these insects provides a rich food source for fungal growth and establishment on mango (Lim and Khoo 1985). Water splash and crawling insects may be the main dispersal agents. Infestation appears to be more frequent on foliage in the lower crown where conditions are more humid. 


\section{Impact}

De Guzman (1977) indicated that heavily infected phyllodes turned yellow and abscissed prematurely with repeated infection, leading to stunting of seedlings. However, on older trees the black mildew does not cause any serious damage although it may be common on the foliage and sometimes on young stems.

\section{Control and management}

Control of the disease is seldom necessary as it has little impact on the host. However, if infestation is heavy, black mildew can be controlled by spraying fungicides and insecticides to eliminate scale insects and mealybugs.

\section{References}

Guzman, E.D. de 1977. Potentially dangerous diseases of forest trees in the Philippines. Biotrop Special Publication No. 2: 189-194.

Lim, T.K. and Khoo, K.C. 1985. Diseases and Disorders of Mango in Malaysia. Tropical Press Sdn. Bhd., 101 p.

Old, K.M., Hood, I.A. and Yuan, Z.Q. 1997. Diseases of tropical acacias in northern Queensland. In: Old, K.M., Lee, S.S. and Sharma, J.K. eds. Diseases of Tropical Acacias. Proceedings of an international workshop, Subanjeriji (South Sumatra), 28 April - 3 May 1996. CIFOR Special Publication, 1-22.

Singh, K.G. 1980. A Check-list of Host and Diseases in Malaysia. Ministry of Agriculture, Malaysia, Bulletin No. 154, 280 p. 

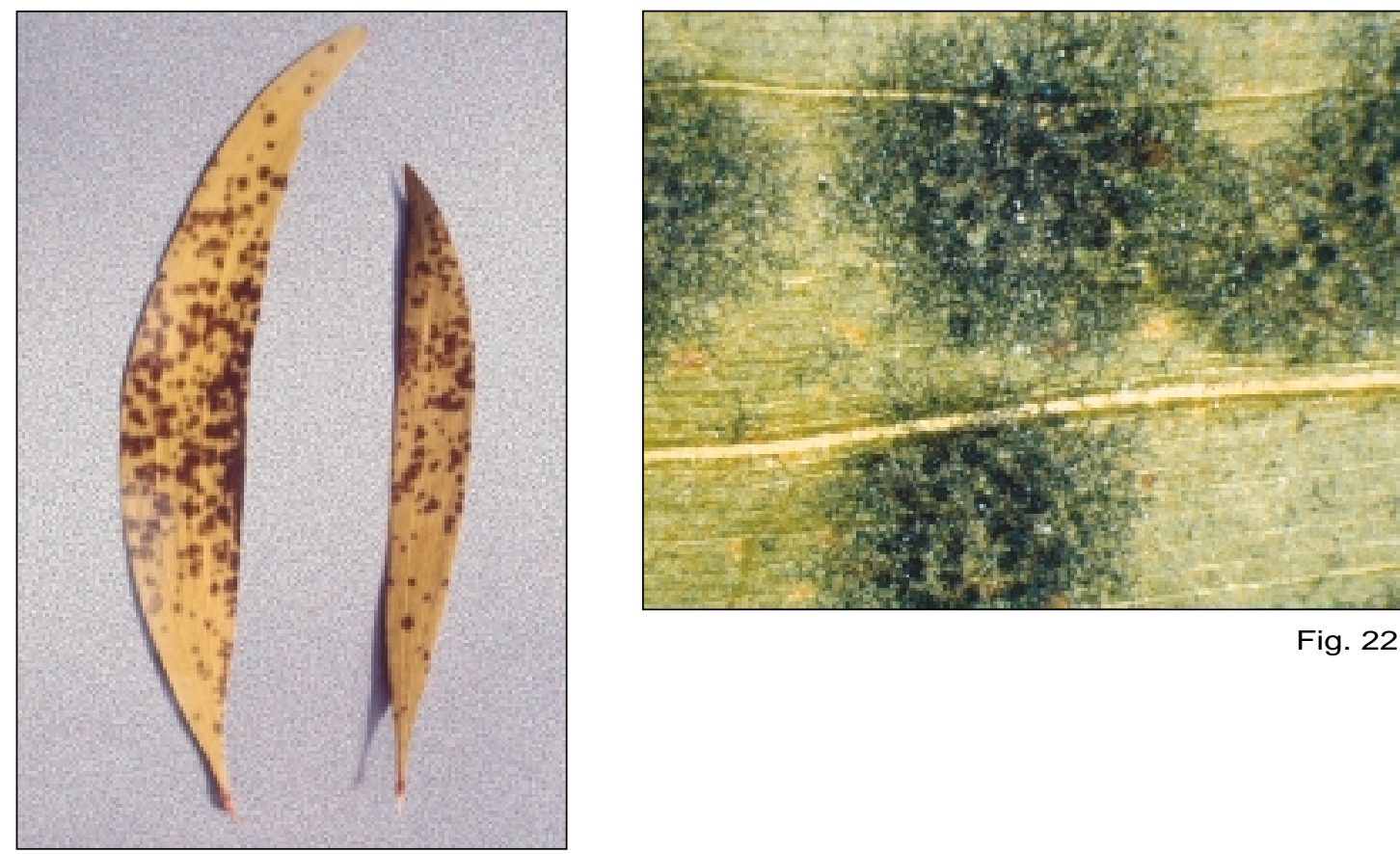

Fig. 22

Fig. 21

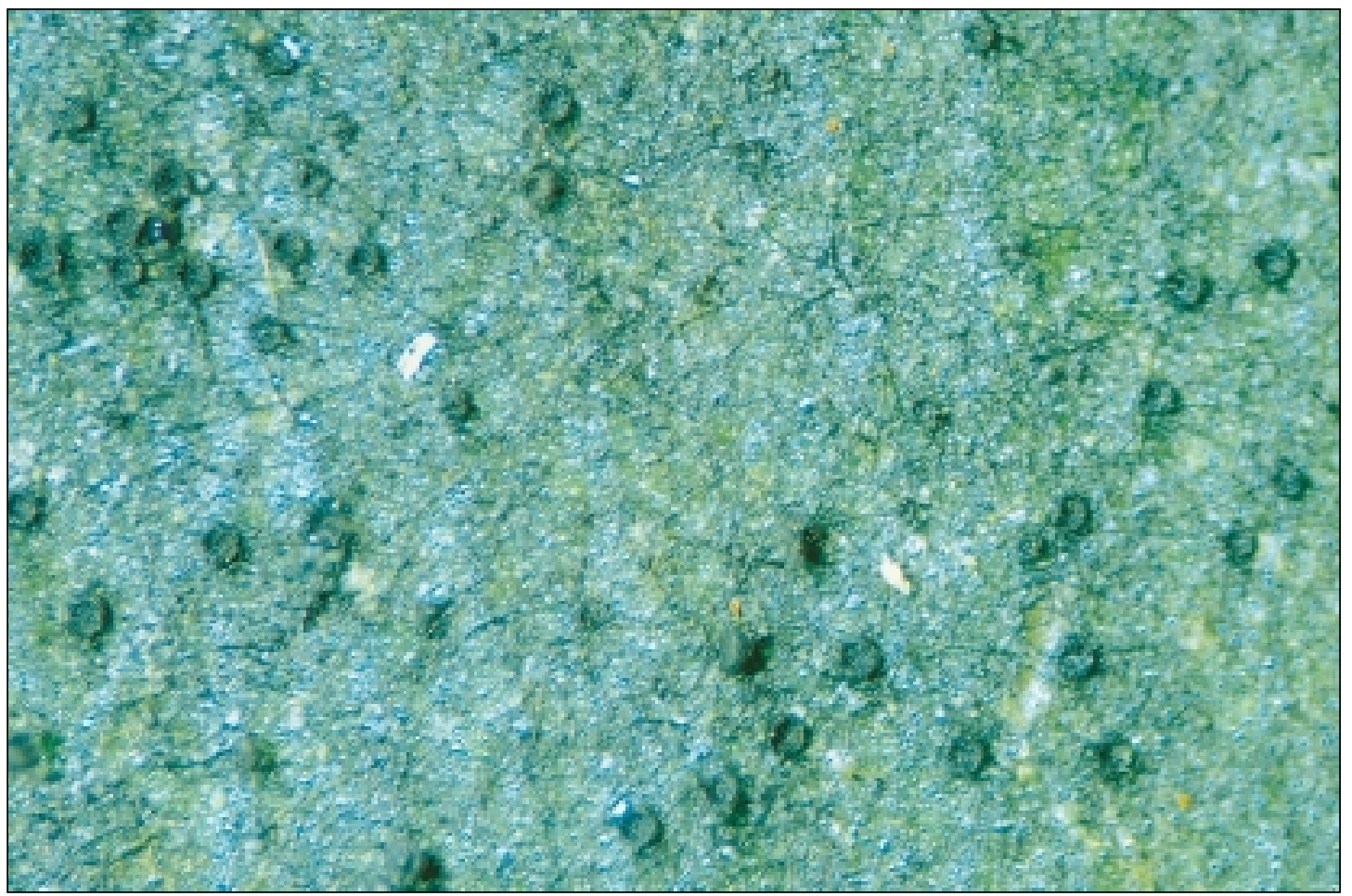

Fig. 23

Fig. 21 Black mildew on Acacia auriculiformis (India)

Fig. 22 Mycelium of Meliola brisbanensis on A. mangium (north Queensland, Australia)

Fig. 23 Perithecia of Meliola sp. on A. mangium (Malaysia) 


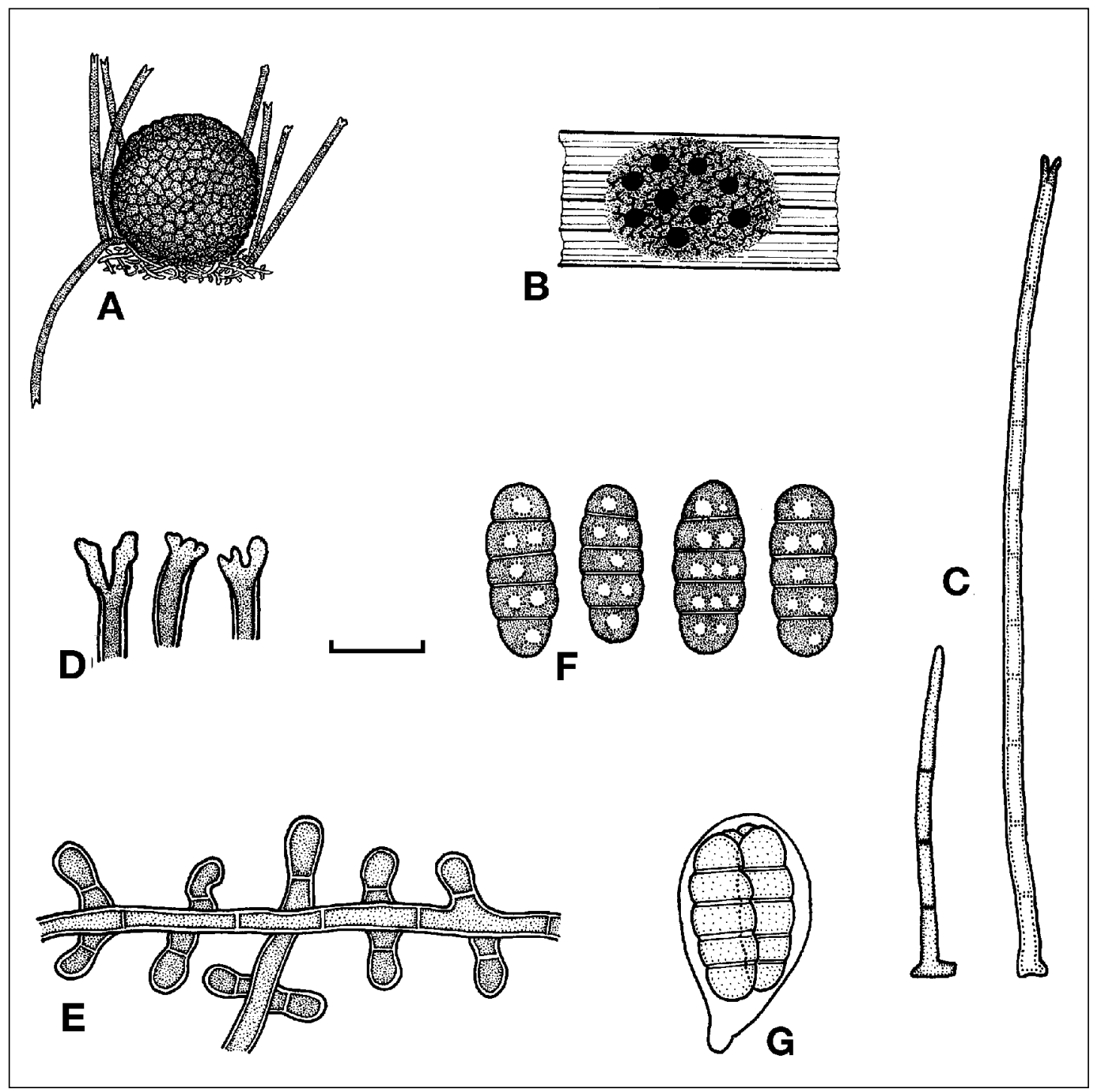

Fig. 24

Fig. 24 Meliola brisbanensis on Acacia aulacocarpa
A. Perithecium surrounded by sterile hyphae (setae)
B. Habit of perithecia on leaf surface
C, D. Detail of setae
E. Hyphae with swollen lateral cells
F. Pigmented septate ascospores
G. Detail of ascus containing four ascospores

$(\mathrm{Bar}=125 \mu \mathrm{m}$ for $\mathrm{A} ;=65 \mu \mathrm{m}$ for $\mathrm{C} ;=35 \mu \mathrm{m}$ for $\mathrm{E} ;=25 \mu \mathrm{m}$ for $\mathrm{D}, \mathrm{F}$ and $\mathrm{G}$; not to scale for $\mathrm{B}$ ) 


\section{ALGAL LEAF SPOT}

\section{Disease}

Algal leaf spot, red rust

\section{Causal organism}

Cephaleuros virescens Kunze, a green alga of the family Trentepohliaceae, order Trentepohliales, division Chlorophyta.

\section{Host range}

This plant parasitic alga is found on an extremely wide range of hosts extending from dicotyledonous trees and shrubs to palms. It can infest both twigs and leaves.

\section{Known distribution}

Algal leaf spot has been reported worldwide between latitudes $32^{\circ} \mathrm{N}$ and $32^{\circ} \mathrm{S}$ on many hosts (Chase and Broschat 1992) including ornamental palms, perennial crops such as cocoa, citrus, cloves, tea, pepper, rubber, mango and other fruit trees. It has also been reported on forest trees such as mahogany and teak (Browne 1968) and is known to occur on the phyllodes of acacias.

\section{Symptoms}

Young lesions first appear on the phyllodes as yellow pinpoint spots, usually on the upper surface. These spots expand into velvety gray-green patches that become purplish-black with a central orange to rust-coloured tuft. Severely infected twigs become enlarged and stunted with sparse, withered leaves (Browne 1968). As the alga can flourish only in humid conditions and on slow-growing tissues, the symptoms are usually most severe on old or suppressed trees.

\section{Pathology}

The orange tufts seen on the phyllode surface (Figs 25-26) constitute the thallus of the alga. The biflagellate zoospores, borne in the sporangia of the alga (Figs 27-29), are disseminated by water-splash and by wind. Initial infection usually occurs towards the end of the humid, rainy seasons. A wet and humid environment in the tree canopy is conducive to the establishment and spread of the disease. The algal thalli penetrate leaf surfaces by mechanical force and grow mainly along the horizontal plane between the leaf cuticle and the epidermal cell layers. Vegetative growth continues until rain or high humidity triggers a reproductive phase. The orange colour of the sporangiospores (Figs 25-26), the reproductive phase of the 
alga, is due to the development of the red pigment, haematochrome. The lesions remain fertile throughout the life of the leaf and for several months after leaf abscission.

\section{Impact}

The disease may be serious when plants are of low vigour or when planted in high-humidity sites with poor air circulation. Overcrowding and poor soil conditions can also indirectly increase host susceptibility to the disease. The disease is also more severe where the host trees are seriously affected by insect attack or by fungal diseases.

Presently there are few reports of serious outbreaks of algal leaf spot on acacias. In India, very high incidence of an unidentified algal spot was reported in combination with sooty mould where severely infected phyllodes turned yellow and were shed prematurely (Sharma and Florence 1997). On some crops the pathogen is known to invade the stems and fruits, and in the palm, Elaeis, high incidence of this disease causes up to $20 \%$ premature senescence of entire leaves (Chase and Broschat 1992). In cases of severe infection on mango, the disease debilitates the tree through reduction of the photosynthetic area (Lim and Khoo 1985).

\section{Control and management}

Since the disease is most severe when plants are stressed by poor soil and by environmental conditions, the most effective means of control and management of the disease is through proper cultural practices. Plant vigour can be ensured by good nutrient applications. Selective pruning and thinning can be carried out to improve air circulation and penetration of sunlight, thereby reducing disease incidence. On some food crops the disease has been controlled by the application of copper fungicides and slaked lime, timed to coincide with the end of the rainy season.

\section{References}

Browne, F.G. 1968. Pests and Diseases of Forest Plantation Trees: An Annotated List of the Principal Species Occurring in the British Commonwealth. Clarendon Press, Oxford, $1330 \mathrm{p}$.

Chase, A.R. and Broschat, T.K. eds. 1992. Diseases and Disorders of Ornamental Palms. Second Printing. APS Press, St Paul, Minnesota, 56 p.

Lim, T.K. and Khoo, K.C. 1985. Diseases and Disorders of Mango in Malaysia. Tropical Press Sdn. Bhd., 101 p.

Sharma, J.K. and Florence, E.J.M. 1997. Fungal pathogens as a potential threat to tropical acacias: case study of India. In: Old, K.M., Lee, S.S. and Sharma, J.K. eds. Diseases of Tropical Acacias. Proceedings of an international workshop, Subanjeriji (South Sumatra), 28 April - 3 May 1996. CIFOR Special Publication, 70-107. 


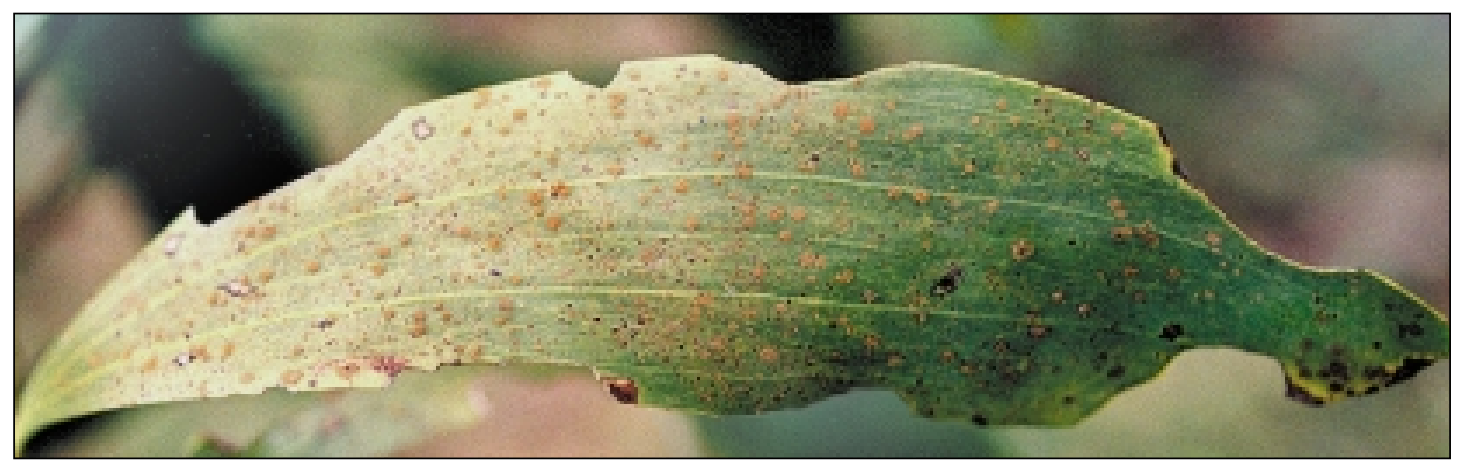

Fig. 25

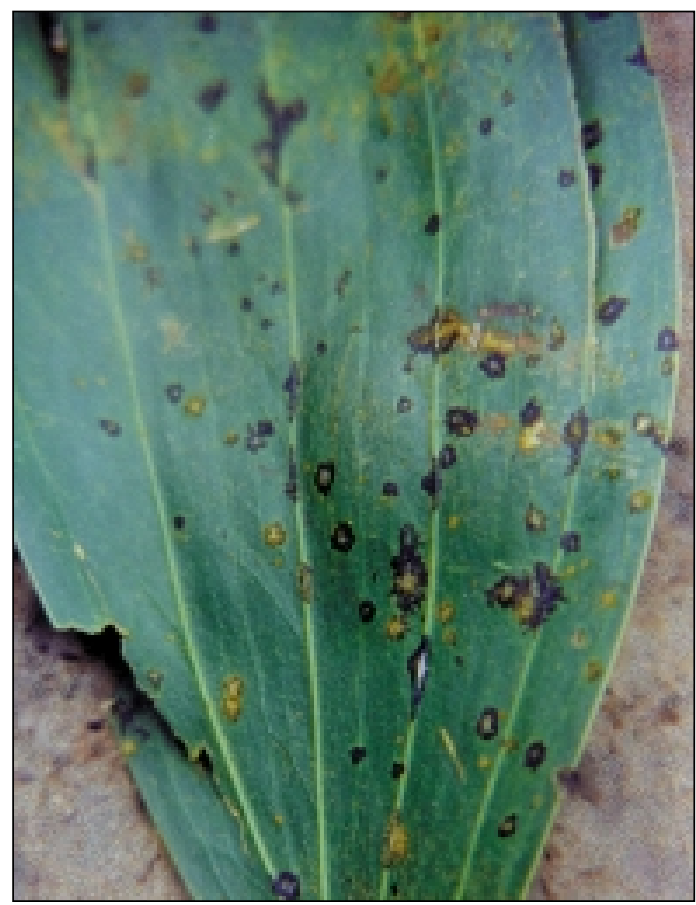

Fig. 26
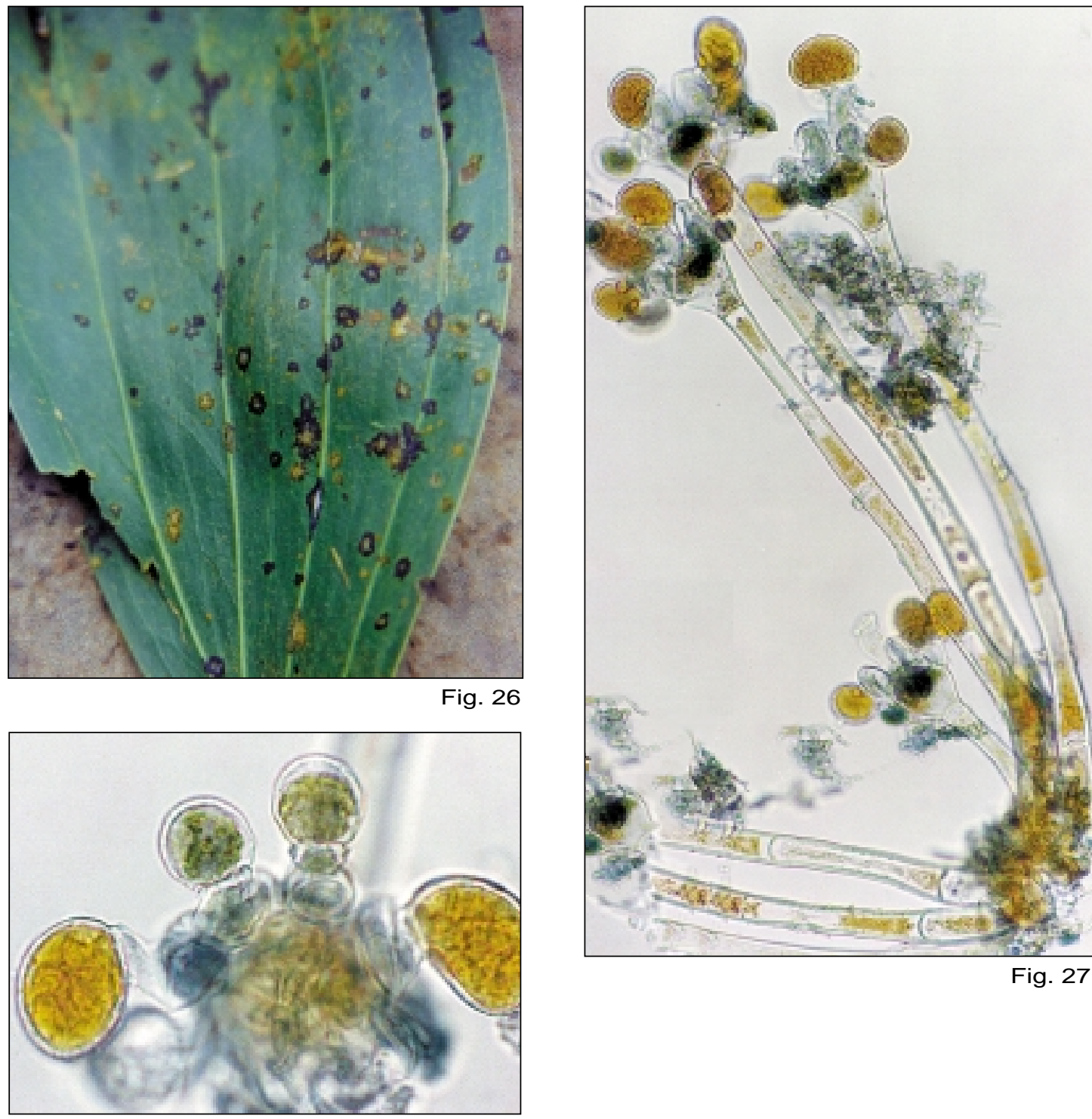

Fig. 27

Fig. 28

Figs 25-26 Acacia mangium affected by Cephaleuros virescens (Thailand, Vietnam) Figs 27-28 Sporangiophores of $C$. virescens bearing sporangia (Thailand) 

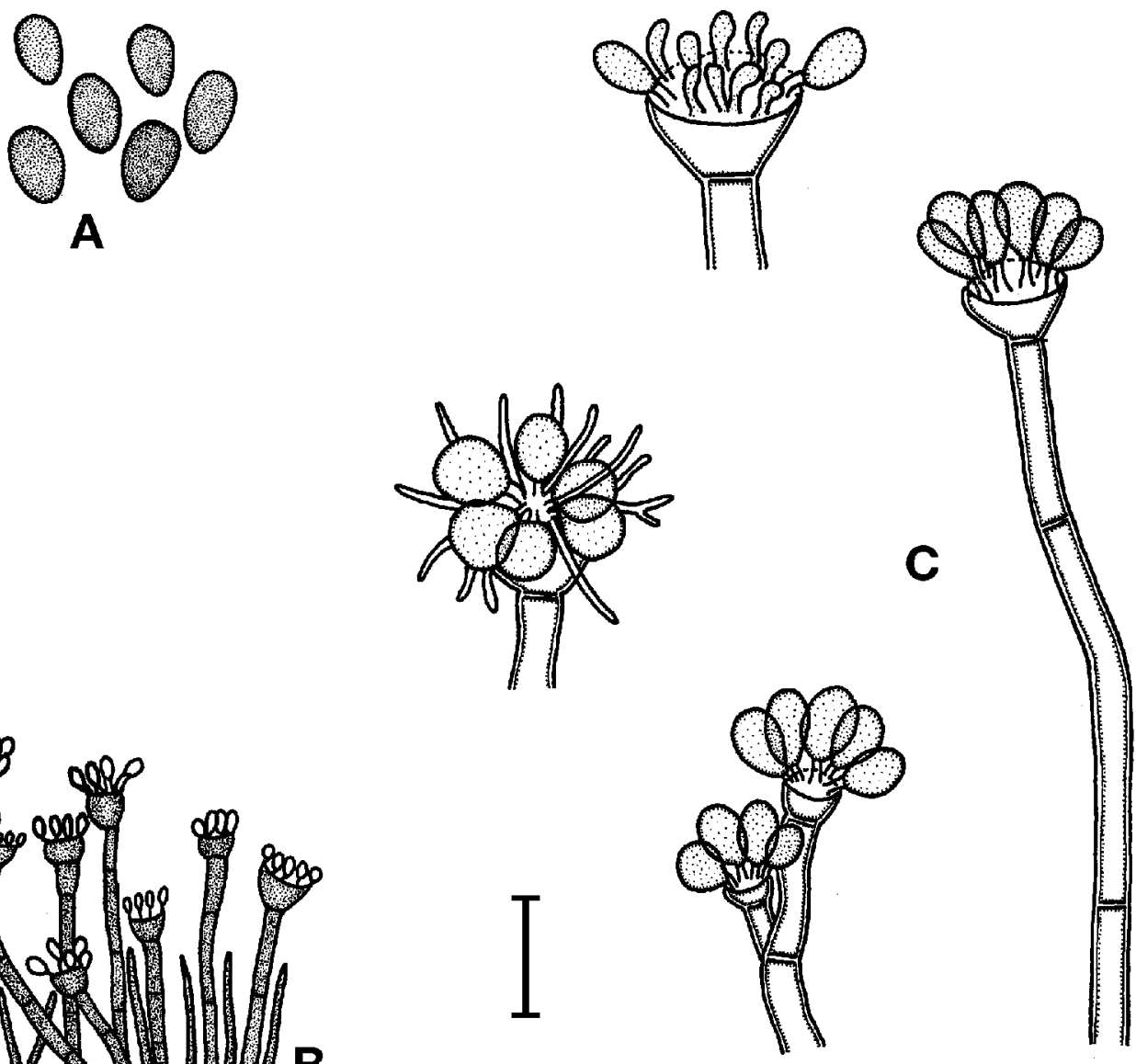

Fig. 29

Fig. 29 Cephaleuros virescens on Acacia mangium
A. Sporangiospores
B. Habit of thallus, sterile cells and sporangia
C. Details of sporangia
$(\mathrm{Bar}=40 \mu \mathrm{m}$ for $\mathrm{A}$ and $\mathrm{C} ;=160 \mu \mathrm{m}$ for $\mathrm{B})$ 


\section{CYLINDROCLADIUM FOLIAR SPOT AND \\ FOLIAR BLIGHT}

\section{Disease}

Cylindrocladium foliar blight

\section{Causal organisms}

Cylindrocladium spp. are widespread and damaging pathogens of a very wide range of plant hosts including acacias. Many Cylindrocladium spp. are known to have perfect stages in the genus Calonectria de Not. Those species of Cylindrocladium known to be associated with foliar infections of Acacia spp. include C. crotalariae (Loos) Bell \& Sobers, C. ilicicola (Hawley) Boedijn \& Reitsma, C. quinqueseptatum Boedijn \& Reitsma (Calonectria quinqueseptata Figueiredo \& Namekata), C. scoparium Morgan and $C$. theae (Petch) Subramanian (Calonectria theae Loos).

\section{Host range}

C. scoparium causes foliar infection, and stem and root rot of Acacia spp. in Australia (Bertus 1976), foliar spots of A. longifolia in South Africa (Hagemann and Rose 1988) and foliar infection of naturally regenerated seedlings and lower branches of A. auriculiformis in Kerala, India (Sharma and Florence 1997). C. quinqueseptatum causes severe foliar spots of A. mangium and A. auriculiformis (Mohanan and Sharma 1988). C. ilicicola also has been reported to cause leaf blight of A. auriculiformis in India (Abraham et al. 1996). C. crotalariae is pathogenic on phyllodes and roots of Acacia spp. and Eucalyptus spp. (Peerally 1974a). Another foliar pathogen of Acacia spp. and Eucalyptus spp. in Sri Lanka and the USA is $C$. theae (Peerally 1974b). This fungus causes foliar spots, blights, collar rot and root rot in various Acacia species.

\section{Known distribution}

As listed above, tropical acacias are subject to attack by several Cylindrocladium spp. in many parts of the world, notably $C$. quinqueseptatum on A. mangium and A. auriculiformis (Abraham et al. 1996; Mohanan and Sharma 1988; Sharma and Florence 1997). Damage occurs mainly in nurseries, and members of this genus do not appear to have caused significant disease in either native forests or plantations of acacias in the tropics.

\section{Symptoms}

On young phyllodes, symptoms include greyish water-soaked spots which coalesce and develop into extensive necrotic areas, usually along the margins and tips. At this time large 
numbers of white spores (Fig. 30) can be seen on the surface of the phyllodes. Under favourable conditions of high humidity and frequent rainfall, the spots further spread to cover the entire area of the phyllode inducing leaf blight symptoms (Fig. 31). Affected phyllodes turn reddish brown (Fig. 32) and are prematurely shed.

Conidia of Cylindrocladium are typically cylindrical in shape with one or more cross walls (septa). Fig. 33 shows fruiting structures produced by $C$. quinqueseptatum, including six-celled macroconidia, two-celled microconidia, vesicles at the tips of sterile hyphae, barrelshaped phialides which give rise to the conidia, and pigmented chlamydospores. The latter are swollen hyphal cells that develop pigmentation and are resistant to biodegradation, thereby aiding survival in soil.

\section{Pathology}

Cylindrocladium spp. cause different types of diseases on acacias including root rot, collar rot, twig blight, leaf blight, foliar spots and die-back. Severe foliar infections develop during conditions of high rainfall and humidity. The spread of the disease is by means of conidia (Figs 30, 33) which are borne in vast numbers on the leaf surface and spread to cause new infections on individual phyllodes. During heavy rain these spores are splashed into the air and infect nearby trees. Infections usually appear on the foliage of lower branches and proceed upwards consistent with the soil-borne nature of the pathogen. Severe infection of phyllodes usually results in premature and extensive defoliation.

\section{Impact}

Cylindrocladium foliar blight has not been a major problem on tropical acacias, unlike its impact on eucalypts grown in the humid tropics. In certain areas, e.g. in southern India where conducive microclimatic conditions commonly occur, C. quinqueseptatum can cause significant damage (Fig. 31). The most common circumstances are in nurseries, where young plants are grown in moist conditions, or among naturally regenerated seedlings under forest canopies where high humidity, high density of seedlings and poor light conditions combine to create environments conducive to disease.

\section{Control}

In nurseries, Cylindrocladium infection can be effectively controlled by carbendazim applied as a foliar spray or soil drench (Sharma et al. 1985). However, in plantations it is not economically feasible to control the disease by fungicidal treatment. The disease on acacias, unlike that on eucalypts, has not been severe enough to warrant selection of resistant genotypes for plantations.

\section{References}

Abraham, K., Beena, S., Cherian, K.A. and Mathew, S.K. 1996. Cylindrocladium leaf blight of Acacia auriculiformis A. Cunn. Journal of Tropical Agriculture 34: 75. 
Bertus, A.L. 1976. Cylindrocladium scoparium Morgan on Australian native plants in cultivation. Phytopathologische Zeitschrift 85: 15-25.

Hagemann, G.D. and Rose, P.D. 1988. Leafspot and blight on Acacia longifolia caused by Cylindrocladium scoparium: a new host record. Phytophylactica 20: 311-316.

Mohanan, C. and Sharma, J.K. 1988. Diseases of exotic acacias in India. Journal of Tropical Forestry 4: 357-361.

Peerally, A. 1974a. Calonectria crotalariae (conidial state: Cylindrocladium crotalariae). CMI Descriptions of Pathogenic Fungi and Bacteria No. 429. Commonwealth Mycological Institute, Kew, England, 2 p.

Peerally A. 1974b. Calonectria theae (conidial state: Cylindrocladium theae) CMI Descriptions of Pathogenic Fungi and Bacteria No. 421. Commonwealth Mycological Institute, Kew, England, 2 p.

Sharma, J.K. and Florence, E.J.M. 1997. Fungal pathogens as a potential threat to tropical acacias; case study of India. In: Old, K.M., Lee, S.S. and Sharma, J.K. eds. Diseases of Tropical Acacias. Proceedings of an international workshop, Subanjeriji (South Sumatra), 28 April - 3 May 1996. CIFOR Special Publication, 70-107.

Sharma, J.K., Mohanan, C. and Florence, E.J.M. 1985. Disease survey in nurseries and plantations of forest tree species grown in Kerala. Kerala Forest Research Institute Research Report No. 85, 268 p. 


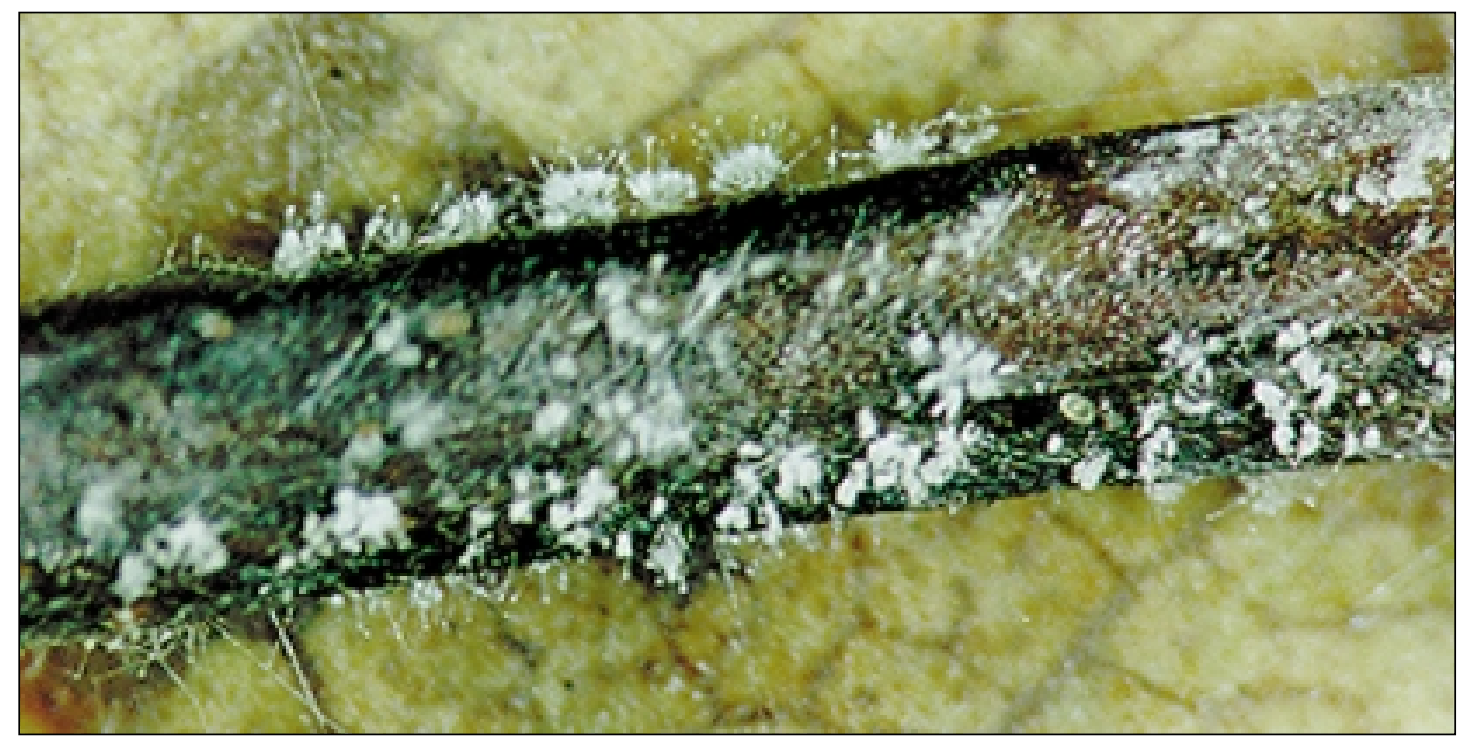

Fig. 30

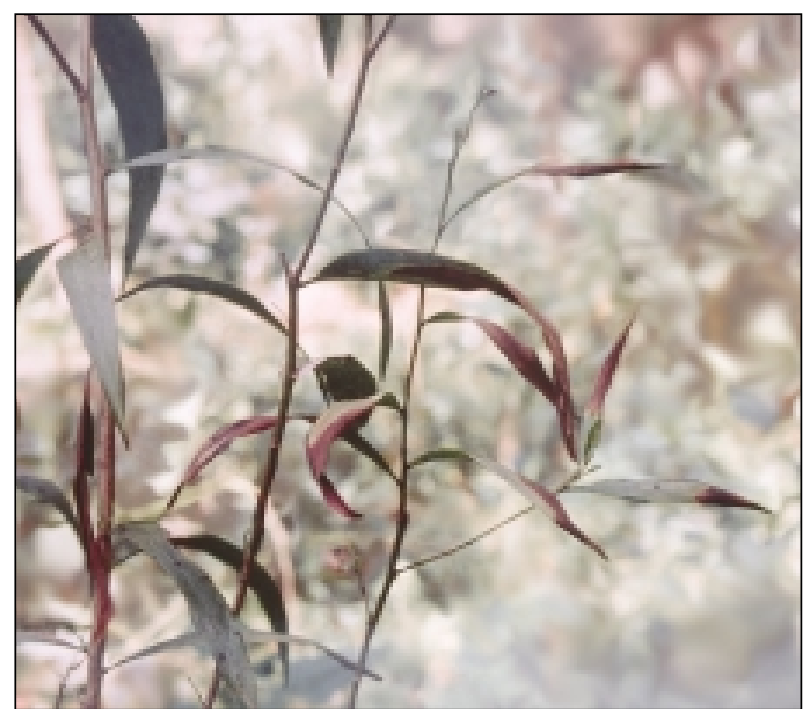

Fig. 31

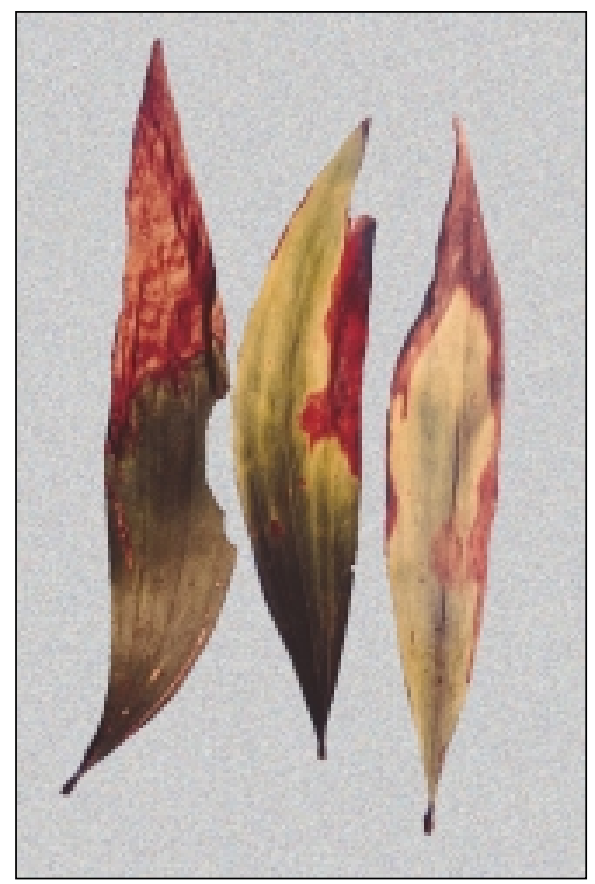

Fig. 32

Fig. 30 Conidiophores and conidia of Cylindrocladium quinqueseptatum on a eucalypt leaf midrib (Thailand)

Fig. 31 Leaf and shoot blight of Acacia auriculiformis caused by C. quinqueseptatum (India)

Fig. 32 Foliar blight caused by $C$. quinqueseptatum (India) 


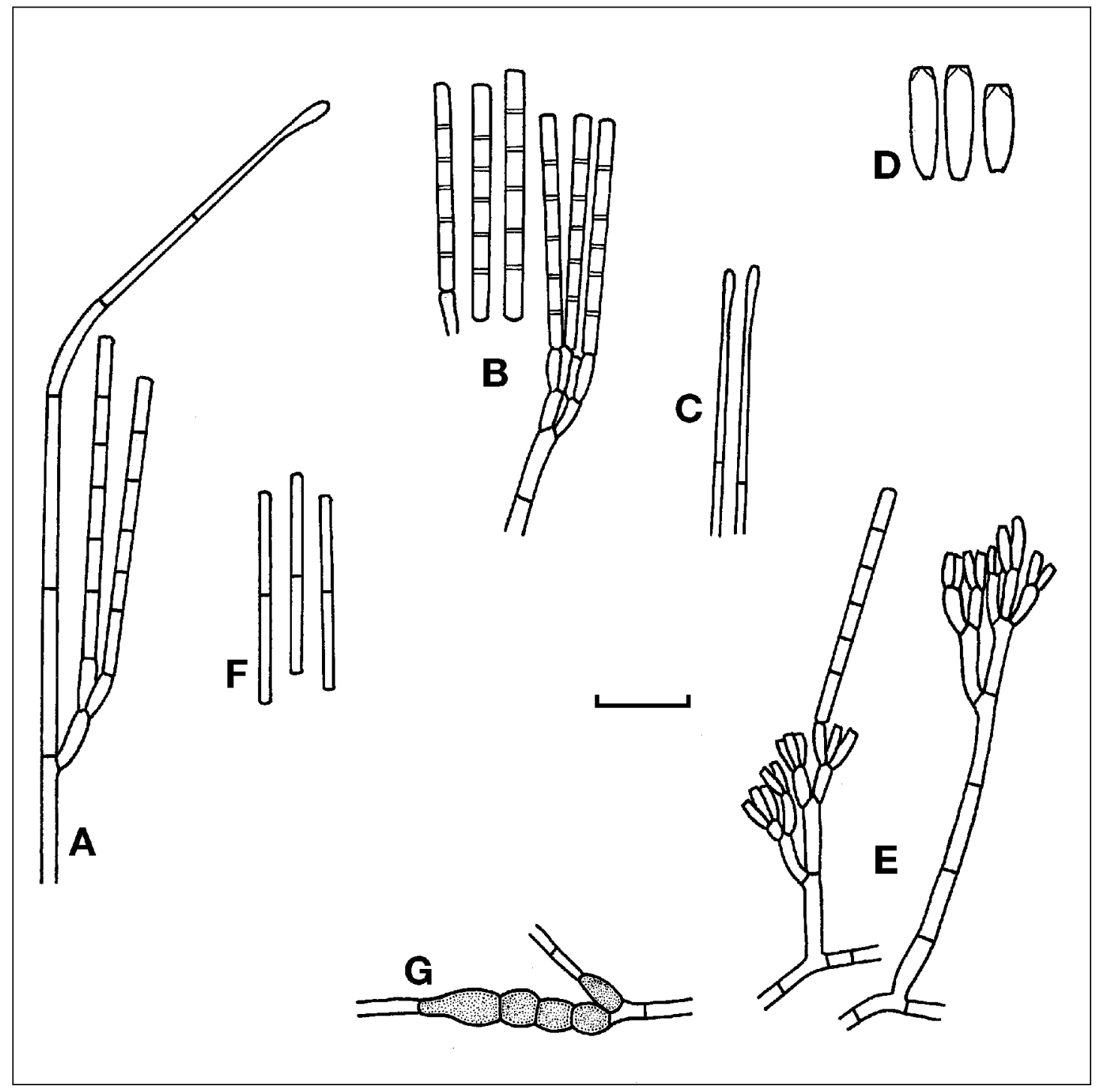

Fig. 33

Fig. 33 Cylindrocladium quinqueseptatum
A. Conidiophore terminating in a vesicle
B. Typical branched conidiophores and conidia
C. Vesicles
D. Phialides, cells which bear conidia
E. Conidiophores on agar culture can be more densely branched
F. Two-celled microconidia produced on agar culture
G. Chlamydospores produced on agar cultures
$(\mathrm{Bar}=30 \mu \mathrm{m}$ for $\mathrm{A}-\mathrm{C}, \mathrm{E}-\mathrm{G} ;=15 \mu \mathrm{m}$ for $\mathrm{D})$ 


\section{CERCOSPORA AND PSEUDOCERCOSPORA FOLIAR DISEASE}

\section{Disease}

Cercospora and Pseudocercospora foliar disease

\section{Causal organisms}

Two as yet un-named foliar pathogens in the genera Cercospora and Pseudocercospora.

\section{Host range}

Cercospora sp. infected seedlings of Acacia mangium and A. auriculiformis raised in a nursery at Ingham, Queensland in 1990 and subsequently planted out at several locations in northern Queensland (Old et al. 1996). The pathogenicity of this fungus to other tropical acacias has not been tested. During surveys to determine the extent and occurrence of Cercospora sp. on acacias in plantations and native acacias in northern Australia, a similar fungus was found on A. crassicarpa. At first it was thought that this was the same species as that implicated in the outbreak, but the fungus on A. crassicarpa has been tentatively identified as a Pseudocercospora sp. (Cannon et al. 1997). Pseudocercospora was also collected on A. flavescens (Old et al. 1997).

\section{Known distribution}

During the 1990 outbreak in northern Queensland, Cercospora sp. became established in trial plantings of $A$. mangium seedlings at nine locations between Lannercost and Innisfail. All these plantings could be traced back to the original Ingham nursery outbreak. Despite annual visits 1993-1999 by K. Old and pathologists from the Queensland Forestry Research Institute to the region, including sites where serious damage occurred to A. mangium, the disease has not been found since 1991.

Pseudocercospora sp., on the other hand, has been collected from plantation-grown A. crassicarpa on Melville Island in the Northern Territory of Australia. The fungus has also been found at several locations in northern Queensland extending over a large part of the natural range of $A$. crassicarpa (Yuan 1996; Old et al. 1997). A significant outbreak of this disease occurred in a trial planting of A. crassicarpa near Cardwell, north Queensland in 1999.

Neither of these fungi appear to have been have been recorded outside Australia, but several species in the genera Cercospora and Pseudocercospora have been described on Acacia in India. These include $P$. acaciae on leaves of $A$. concinna (Kamal 1980). Pongpanich recorded a Cercospora sp. as causing a pod rot of A. auriculiformis in Thailand (Pongpanich 1997). The relationship between these fungi and the Australian collections needs further study. 


\section{Symptoms}

The symptoms produced by both fungi are similar. Phyllodes bear spots, blotches and more extensive reddish-brown necrotic areas with scattered, or more densely arrayed, sporulating structures (Figs 35-36). With the dissecting microscope these structures can be seen to bear cylindrical spores which are non-pigmented in the case of Cercospora and pigmented in the case of Pseudocercospora (Fig. 37). This distinction is not always clear and further diagnosis may need specialist assistance with detailed examination of sporulating colonies and fruiting structures (Fig. 37). Spores are 1-5 septate. Infected phyllodes often become distorted or crinkled (Figs 34-35). Experience in north Queensland indicates that Cercospora sp. is a potentially more serious pathogen than the Pseudocercospora sp.

\section{Pathology}

The pathology of disease caused by Cercospora and Pseudocercospora on acacias has not been systematically studied. The outbreak of Cercospora disease in the Ingham nursery and the subsequent failure to find the pathogen in native stands or in plantations not traceable to the nursery outbreak suggested that the pathogen (in common with some other Cercospora spp.) may be seed-borne. As the disease was first noticed in provenances of $A$. mangium originating in Papua New Guinea, it was possible that this represented a newly introduced pathogen borne on seed. This possibility was pursued by an intensive study of seedlots in storage but no Cercospora isolations were made from 35 bulk seedlots imported from PNG (Old et al. 1996). The Pseudocercospora sp. found in plantations and native stands of A. crassicarpa in northern Australia appears to be indigenous to the region.

\section{Impact}

The impact of Cercospora sp. on seedlings in the nursery and young plantations of A. mangium was very damaging (Bruce Brown, personal communication); many trees died and the extensive infections caused multiple branching and severe degradation of form. As a result of the epidemic in a seed orchard at Kuranda, north Queensland, a 1.5 ha seed stand was abandoned (Old et al. 1996). Impacts of this severity on tropical acacias caused by Cercospora spp. do not appear to have been recorded in countries of South-East Asia where acacias are grown as exotic plantations.

In 1992 Pseudocercospora was observed in a seed orchard at Yapilika in Melville Island, Northern Territory. First symptoms were seen at the age of 6 months when trees were 2-3 m tall. The major damage was in the upper crown and significant defoliation had occurred in many trees by age 1.3 years when the trees were about $5 \mathrm{~m}$ tall. Impacts of this pathogen in other trial plantations of A. crassicarpa in north Queensland have been small with the exception of the 1999 outbreak near Cardwell where significant upper crown damage occurred (Fig. 34). Damage in native trees has mainly been observed in young regrowth. It was noticeable that where regrowth A. mangium and A. crassicarpa occurred together, only the latter species was infected. 


\section{References}

Cannon, P., Pascoe, I., Beilharz, V. and Yuan, Z.Q. 1997. Report on fungi from diseased acacia samples examined at Institute of Horticultural Development, Knoxfield. In: Old, K.M., Lee, S.S. and Sharma, J.K. eds. Diseases of Tropical Acacias. Proceedings of an international workshop, Subanjeriji (South Sumatra), 28 April - 3 May 1996. CIFOR Special Publication, 108-113.

Kamal, S.R.P. 1980. Fungi of Gorakhpur XIX. Pseudocercospora. Sydowia 33: 157-161.

Old, K.M., Harwood, C.E., Robson, K.J., Haines, M.W. and Solomon, D.J. 1996. Foliar pathogens of tropical acacias in Australia. In: Nair K.S.S., Sharma J.K. and Varma, R.V. eds. Impact of Diseases and Insect Pests in Tropical Forests. Proceedings of IUFRO Symposium, 23-26 November 1993. Peechi, India, 11-19.

Old, K.M., Hood, I.A. and Yuan, Z.Q. 1997. Diseases of tropical acacias in northern Queensland. In: Old, K.M., Lee, S.S. and Sharma, J.K. eds. Diseases of Tropical Acacias. Proceedings of an international workshop, Subanjeriji (South Sumatra), 28 April - 3 May 1996. CIFOR Special Publication, 1-22.

Pongpanich, K. 1997. Diseases of Acacia species in Thailand. In: Old, K.M., Lee, S.S. and Sharma, J.K. eds. Diseases of Tropical Acacias. Proceedings of an international workshop, Subanjeriji (South Sumatra), 28 April - 3 May 1996. CIFOR Special Publication, 62-67.

Yuan, Z.Q. 1996. Fungi and associated tree diseases in Melville Island, Northern Territory, Australia. Australian Systematic Botany 9: 337-360. 

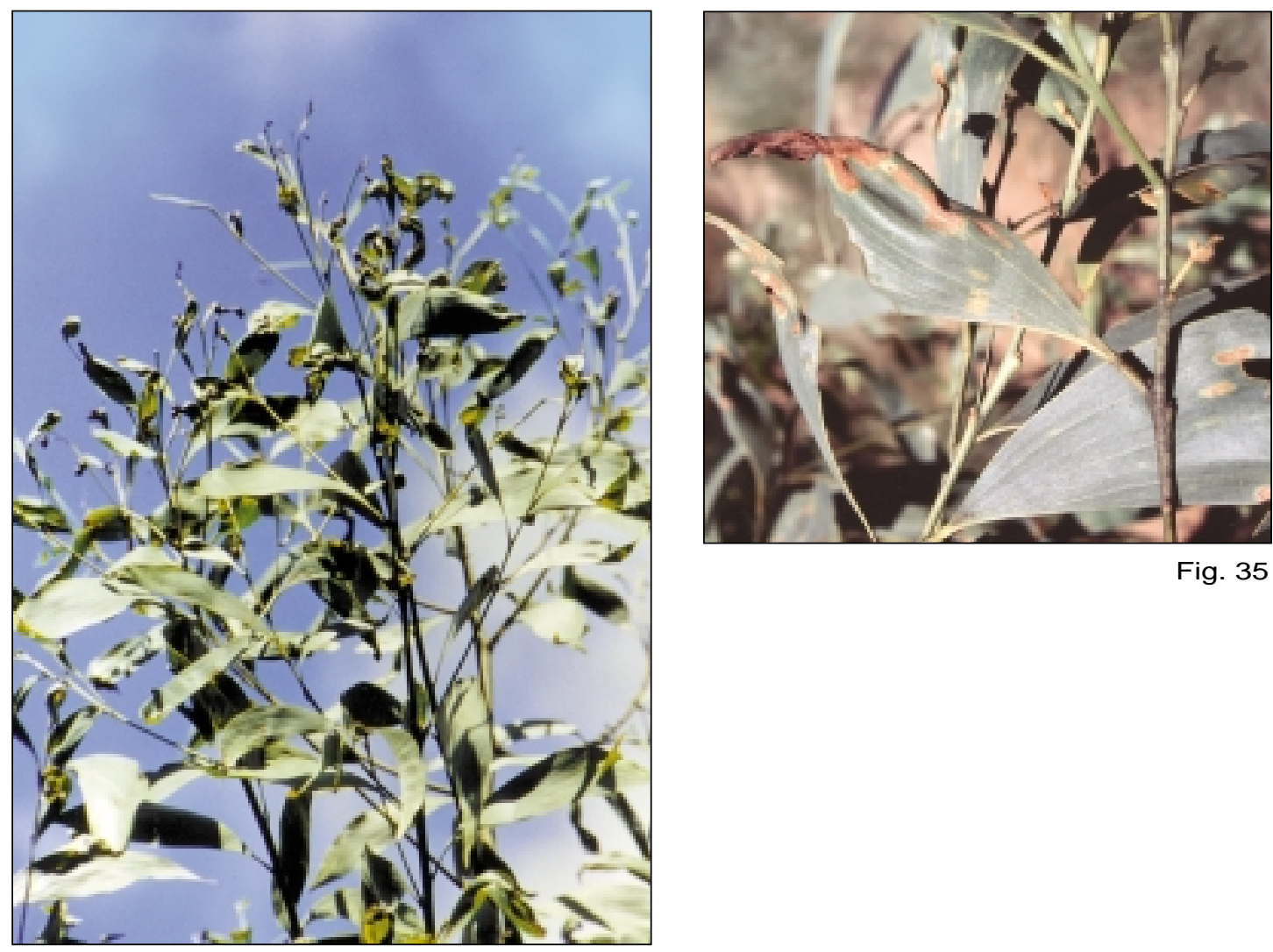

Fig. 35

Fig. 34

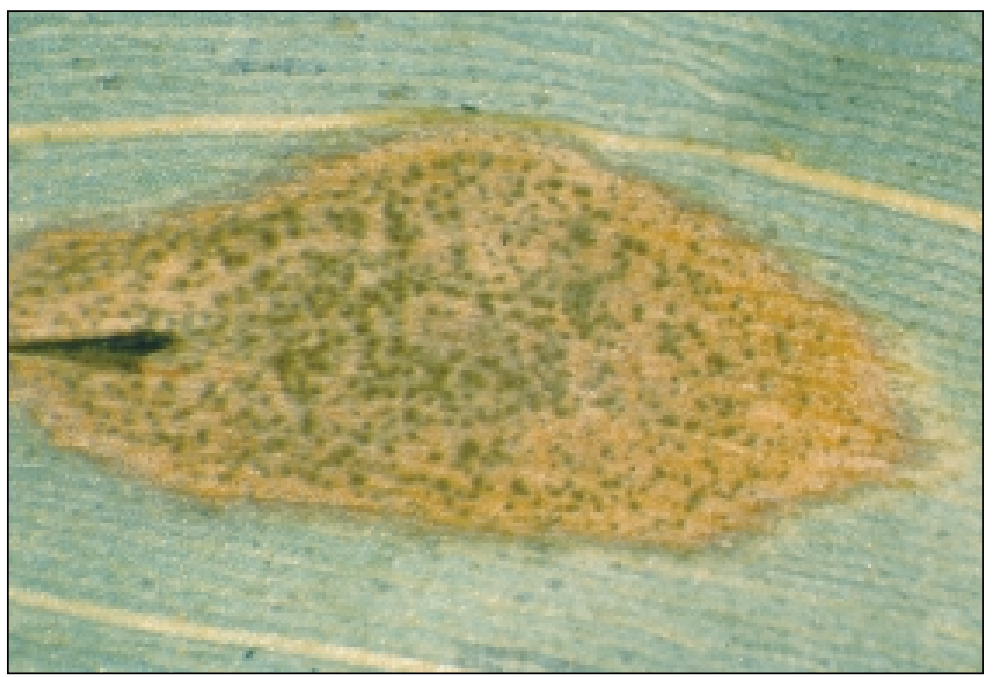

Fig. 36

Fig. 34 Seedling of Acacia mangium infected by Cercospora sp. (north Queensland, Australia) Fig. 35 A. crassicarpa infected by Pseudocercospora sp. (north Queensland, Australia)

Fig. 36 Pseudocercospora sporulating on a lesion from the tree shown in Fig. 35 


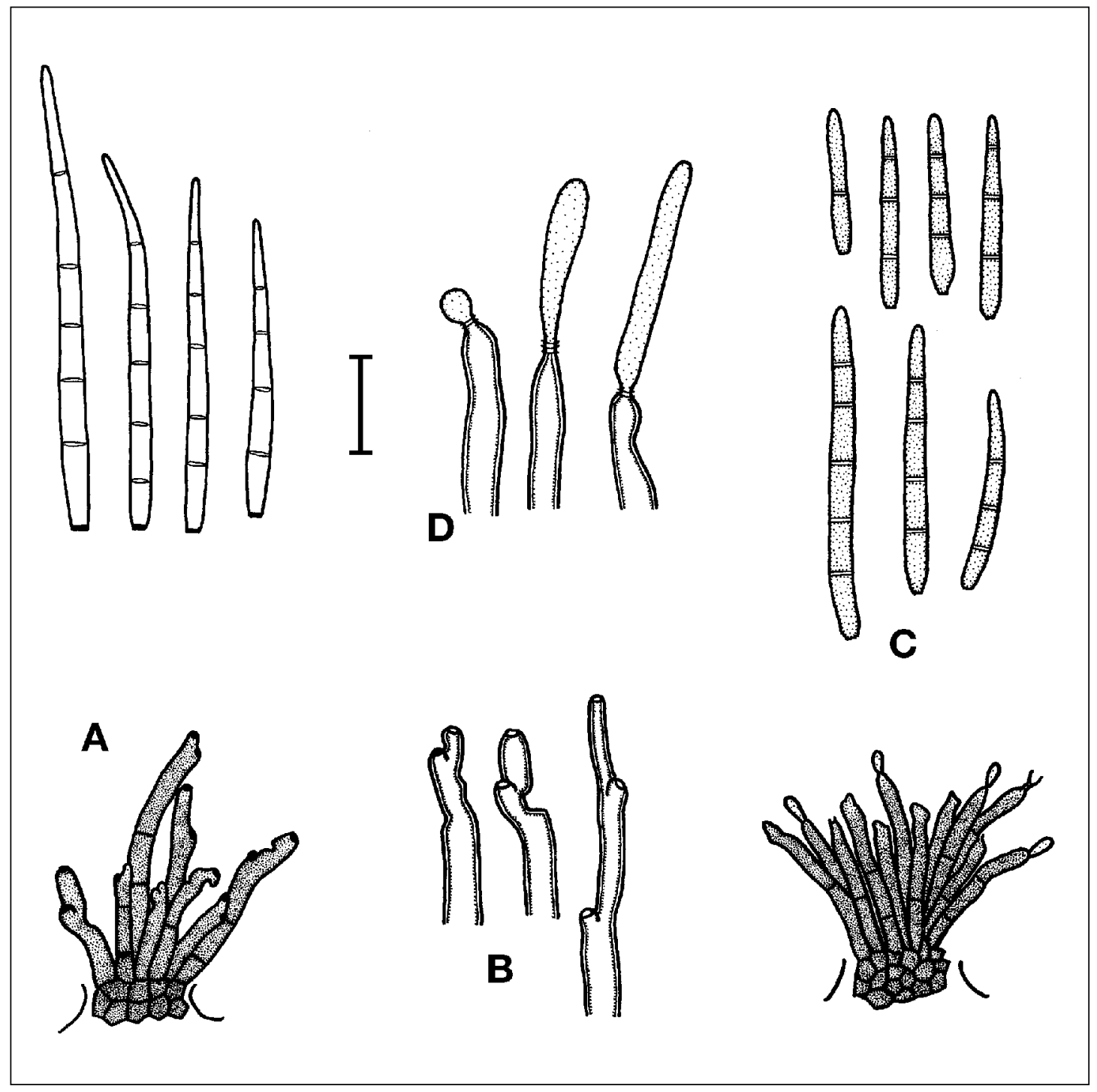

Fig. 37

Fig. 37 Cercospora sp. and Pseudocercospora sp.

A. Conidiophores and conidia of Cercospora sp. on Acacia mangium

B. Detail of conidiogenous cells in A, showing thickened scars

C. Conidiophores and conidia of Pseudocercospora sp. on A. crassicarpa

D. Detail of conidiogenous cells in $\mathrm{C}$ showing annular structures at the point where conidia are attached $(B a r=20 \mu \mathrm{m}$ for $\mathrm{A}$ and $\mathrm{C} ;=10 \mu \mathrm{m}$ for $\mathrm{B}$ and $\mathrm{D})$ 


\section{PHAEOTRICHOCONIS FOLIAR SPOT}

\section{Disease}

Leaf spot, bintik daun (Bahasa Malaysia), bercak daun (Bahasa Indonesia)

\section{Causal organism}

Phaeotrichoconis crotalariae (Salam \& Rao) Subram. A similar and closely related fungus, Helminthosporium (Exserohilum) rostratum (Drechs.) Leonard \& Suggs, was reported by Mohanan and Sharma (1988) to cause a leaf spot on Acacia auriculiformis.

\section{Host range}

This is a pan-tropical fungus with a very wide host range including A. crassicarpa (Old et al. 1996), A. auriculiformis identified as E. rostratum (Mohanan and Sharma 1988), coconut (Miller 1997) and other palms (Chase 1982), cardamom (Dhanalakshmi and Leelavathy 1976), Cyperus iria (Mishra et al. 1972), ornamentals such as Alternanthera sessilis (Ramakrishnan et al. 1972) and vegetable crops. It has also been reported on Noogoora burr, Xanthium pungens, which is an important weed in northern Australia.

\section{Known distribution}

This fungus is very widely distributed in the tropics with many records coming from India, and others from the Northern Territory of Australia and Florida.

\section{Symptoms}

Discrete spots, randomly scattered on the phyllode (Fig. 38). Lesions are oblong or elliptical in shape, reddish in colour with a darkly pigmented margin and paler necrotic tissue toward the centre (Fig. 39). Clusters of large, darkly pigmented conidia are visible through a hand lens. Conidia are very large, up to $40 \times 10 \mu \mathrm{m}$ with long beak-like appendages (Fig. 40). Pigmented sclerotia are produced on culture media.

\section{Pathology and impacts}

The two reports of these fungi on Acacia spp. suggest that they are minor pathogens and unlikely to cause significant damage to plantation acacias. The conspicuous spots which are alluded to by Chase (1982) on palms are, however, likely to attract the attention of plantation managers, warranting inclusion of this disease in the manual. 


\section{References}

Chase, A.R. 1982. Dematiaceous leaf spots of Chrysalidocarpus lutescens and other palms in Florida. Plant Disease 66: 697-699.

Dhanalakshmi, C. and Leelavathy, K.M. 1976. Leaf spot of cardamom caused by Phaeotrichoconis crotalariae. Plant Disease Reporter 60: 188.

Miller, J.W. 1997. Plant pathology. Tri-ology Technical Report 36: 11-12.

Mishra, B., Prakash, O. and Misra, A.P. 1972. Incidence of Phaeotrichoconis crotalariae on Cyperus iria Linn. from India. Science and Culture 38: 371-372.

Mohanan, C. and Sharma, J.K. 1988. Diseases of exotic acacias in India. Journal of Tropical Forestry 4: 357-361.

Old, K.M., Harwood, C.E., Robson, K.J., Haines, M.W. and Solomon, D.J. 1996. Foliar pathogens of tropical acacias in Australia. In: Nair, K.S.S., Sharma, J.K. and Varma R.V. eds. Impact of Diseases and Pests in Tropical Forests. Proceedings of IUFRO Symposium, 23-26 November 1993, Peechi, Kerala, India, 11-19.

Ramakrishnan, C.K., Menon, M.R. and Devi, L.R. 1972. Alternanthera sessilis R.Br.-A new host of Phaeotrichoconis crotalariae (Salam and Rao) Subramanian comb. nov. Current Science 41: 751-752. 


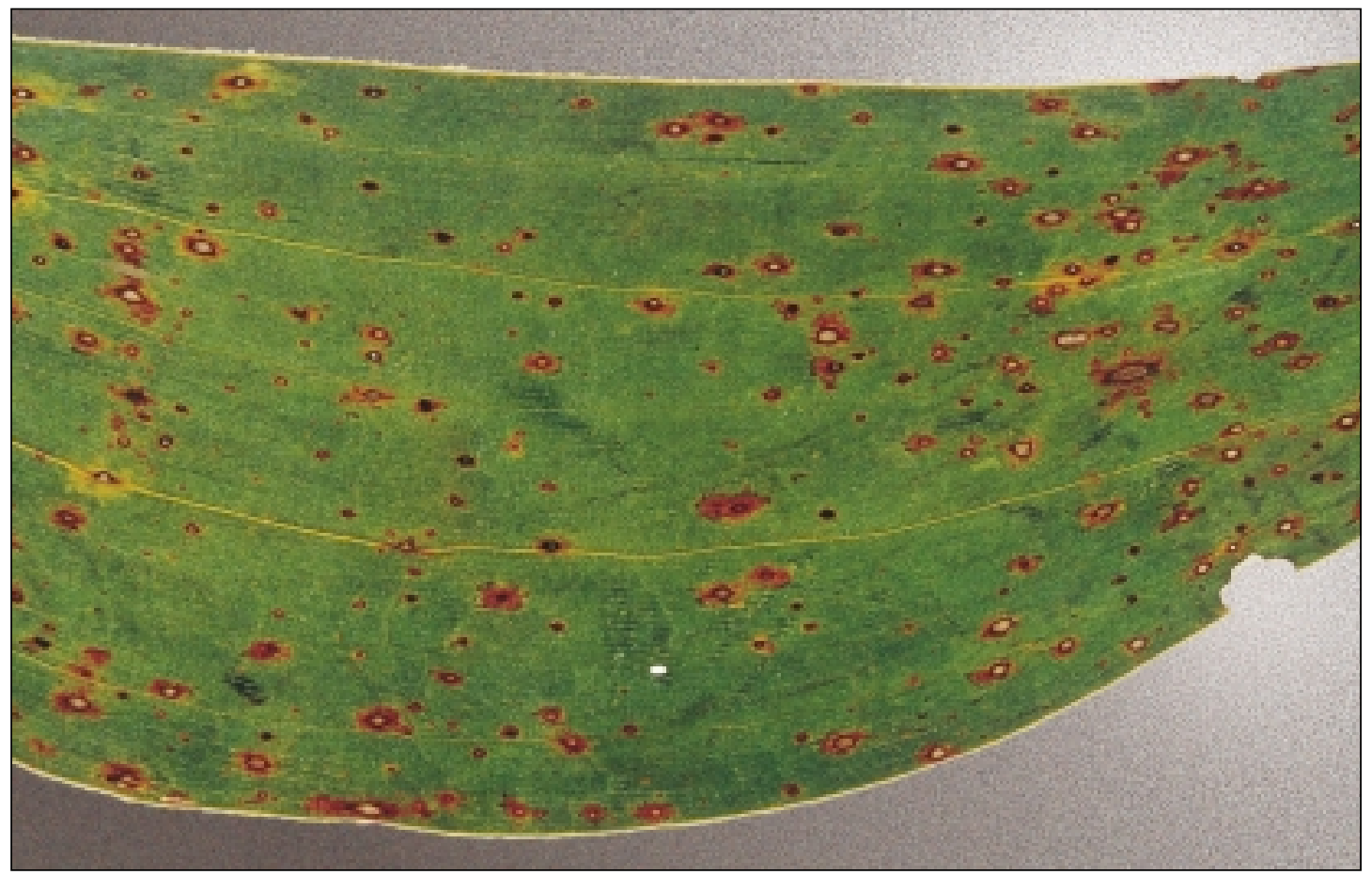

Fig. 38

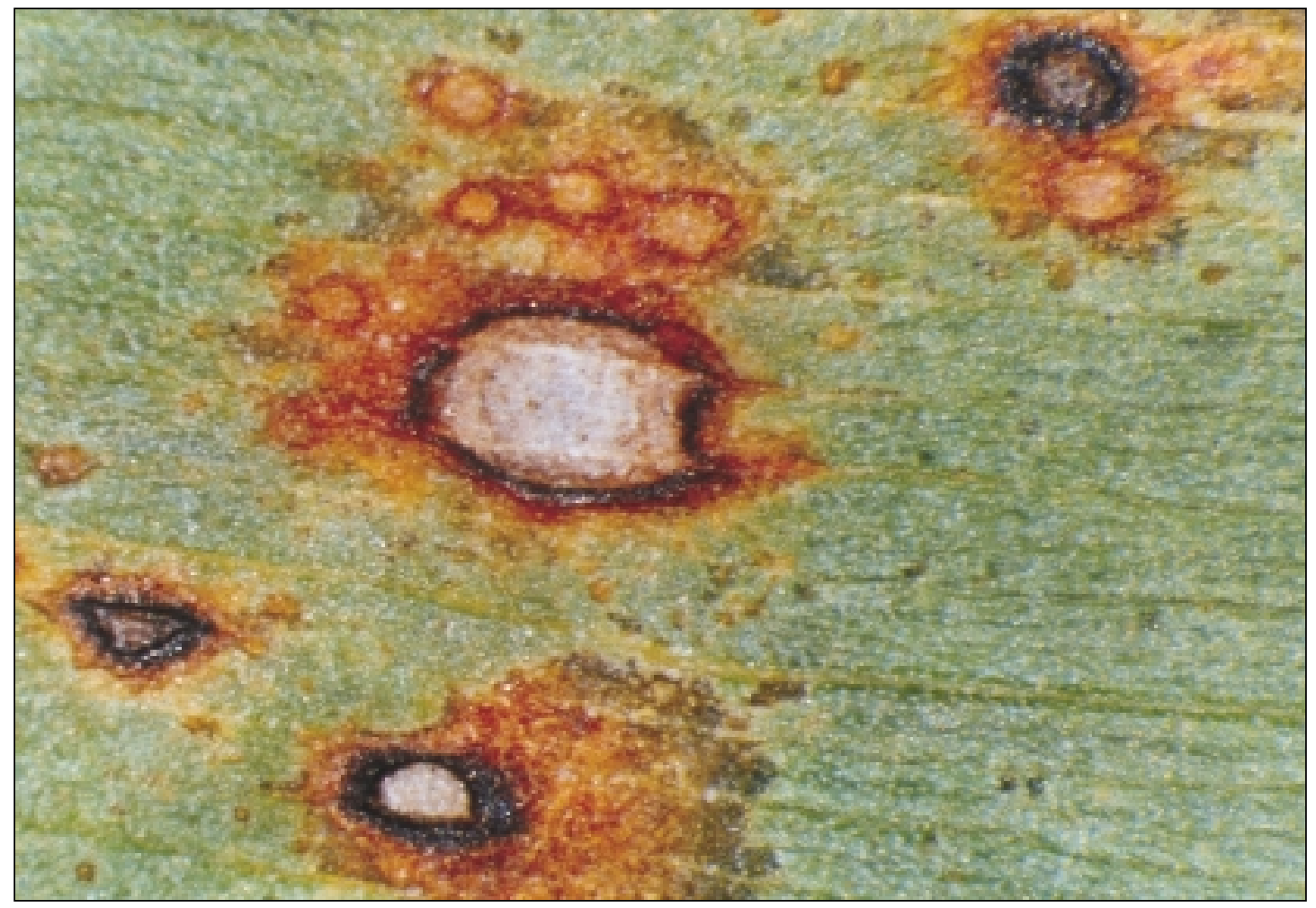

Fig. 39

Fig. 38 Acacia crassicarpa infected by Phaeotrichoconis crotalariae (Northern Territory, Australia) Fig. 39 Detail of lesion on the phyllode shown in Fig. 38 


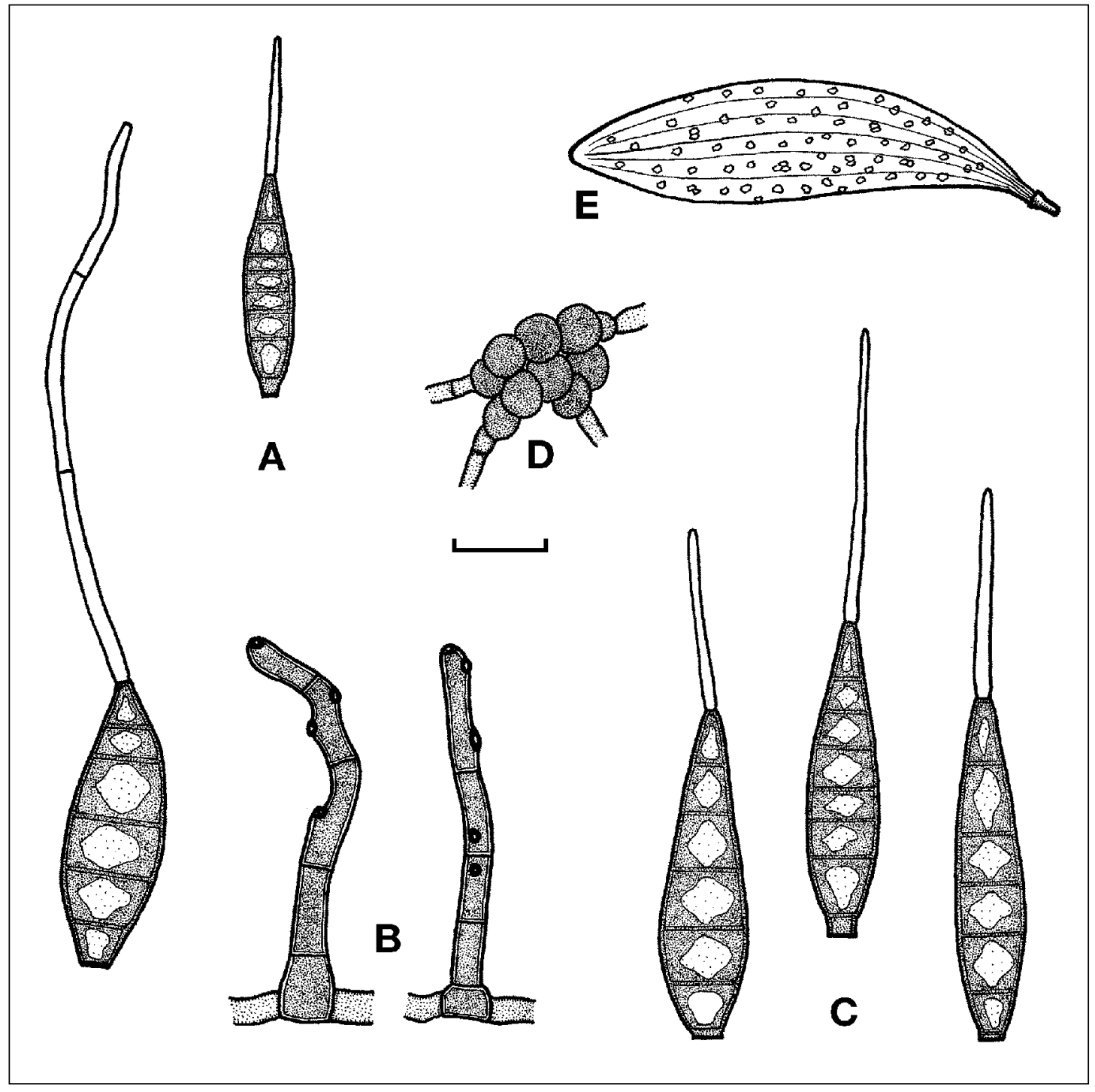

Fig. 40

Fig. 40 Phaeotrichoconis crotalariae on Acacia crassicarpa
A and C. Conidia
B. Conidiophores
D. Chlamydospores on agar culture
E. Spots scattered on a phyllode

(Bar $=20 \mu \mathrm{m}$ for $\mathrm{A}, \mathrm{B}$ and $\mathrm{C} ;=10 \mu \mathrm{m}$ for $\mathrm{D}$; not to scale for $\mathrm{E}$ ) 


\section{COLLETOTRICHUM FOLIAR SPOT}

\section{Disease}

Colletotrichum foliar spot, anthracnose.

\section{Causal organism}

Colletotrichum gloeosporioides (Penz.) Sacc., teleomorph Glomerella cingulata (Stonem.) Spauld. \& Schrenk.

\section{Host range}

Colletotrichum gloeosporioides is worldwide in distribution, affecting a large number of cultivated as well as wild plants, especially in the warm-humid tropics. It is known to cause die-back, leafspots, seedling blight, and leaf blight of several hosts including tropical acacias (Mordue 1971). The leaf spots incited by this pathogen are often called anthracnose, being limited in extent with necrotic areas bounded by brown, black or discoloured margins.

\section{Known distribution}

Anthracnose disease of Acacia phyllodes is reported from various tropical countries. In India, C. gloeosporioides and Colletotrichum sp. cause tip necrosis and foliar spots on four different species of Acacia (Sharma and Florence 1997). Foliar blight of A. aulacocarpa and A. crassicarpa and black spots of A. auriculiformis caused by C. gloeosporioides have been recorded in Thailand (Pongpanich 1997) and in Florida (Barnard and Schroeder 1984). Colletotrichum foliar spot has also been recorded on A. auriculiformis in nurseries and plantations in Vietnam by Sharma (1994). Similar anthracnose diseases, ascribed to Glomerella cingulata, have been described from Acacia spp. in Papua New Guinea, from A. cyanophylla and A. catechu in India (Gibson 1975) and from A. mangium in Malaysia (Maziah 1990).

\section{Symptoms}

Various symptoms, including tip necrosis and foliar spots, are produced by Colletotrichum sp. on different acacias, and even within one species more than one type of symptom may be observed. Some examples of symptoms are illustrated in Figs 41-43. Anthracnose in A. mangium and A. auriculiformis is first seen as circular to oval reddish-brown spots of variable size with raised margins that coalesce to produce larger spots (Fig. 41). Severe infection causes drying and cracking of the phyllode and premature defoliation. In $A$. aulacocarpa, the spots are black, circular to oval, and scattered on the lamina irrespective of the vein arrangement (Fig. 42). In A. crassicarpa (Fig. 43) the disease is characterised by chocolate-brown spots with necrotic centres and darker margins.

The fruiting structures of Colletotrichum spp., called acervuli, are darkly pigmented and contain characteristic sterile, hair-like structures (setae). Conidia lack pigmentation and are ovoid or ellipsoidal in shape (Fig. 44). 


\section{Pathology}

Tip necrosis of Acacia spp., usually observed on mature phyllodes, appears to be insignificant. However, severe anthracnose can occur in the nursery and can be commonly found on lower portions of the canopy in plantations, sometimes associated with premature defoliation. In the field it is more likely to occur on plants suffering from environmental stress, e.g. suppressed trees.

\section{Impact}

Though tip necrosis and anthracnose of acacias caused by Colletotrichum sp. are not generally regarded as serious, in severe cases they may cause defoliation and adversely affect growth (Sharma and Florence 1997).

\section{Control and management}

Even though it is not economical to control the disease in plantations it may be advisable to use fungicides to control it in the nursery. For example, in Florida, anthracnose of Acacia has been controlled by using chlorothalonil (Barnard and Schroeder 1984).

\section{References}

Barnard, E.L. and Schroeder, R.A. 1984. Anthracnose of Acacia in Florida. Occurrence and fungicidal control. Proceedings of the Florida State Horticultural Society 97: 244-247.

Gibson, I.A.S. 1975. Diseases of Forest Trees Widely Planted as Exotics in the Tropics and Southern Hemisphere. Part I. Important members of the Myrtaceae, Leguminosae, Verbenaceae and Meliaceae, Commonwealth Mycological Institute, CAB, U.K., 51p.

Maziah, Z. 1990. Diseases of forest plantation species in Peninsular Malaysia.

In: Hutacharern, C., MacDicken, K.G., Ivory, M.H. and Nair, K.S.S., eds. Pests and Diseases of Forest Plantations in the Asia-Pacific Region, RAPA publication 1990/9, FAO-RAPA, Bangkok, 94-99.

Mordue, J.E.M. 1971. Glomerella cingulata. C.M.I. Descriptions of Pathogenic Fungi and Bacteria. No. 315. Commonwealth Mycological Institute, Kew, England, 2 p.

Pongpanich, K. 1997. Diseases of Acacia species in Thailand. In: Old, K.M., Lee, S.S. and Sharma, J.K. eds. Diseases of Tropical Acacias: Proceedings of an international workshop Subanjeriji (South Sumatra) 28 April - 3 May, 1996. CIFOR Special Publication, 62-67.

Sharma, J.K. and Florence, E.J.M. 1997. Fungal pathogens as a potential threat to tropical acacias; case study of India. In: Old, K.M., Lee, S.S. and Sharma, J.K. eds. Diseases of Tropical Acacias: Proceedings of an international workshop Subanjeriji (South Sumatra) 28 April - 3 May, 1996. CIFOR Special Publication, 70-107.

Sharma, J.K. 1994. Pathological investigations in forest nurseries and plantations in Vietnam. Consultancy Report UNDP/FAO Project Vie/92/022, Hanoi, Vietnam, 46 p. 


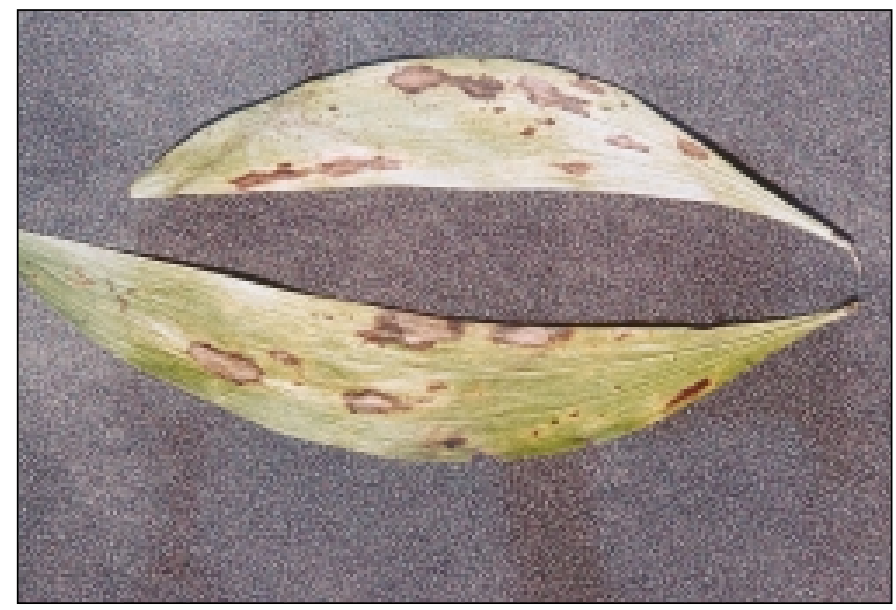

Fig. 41

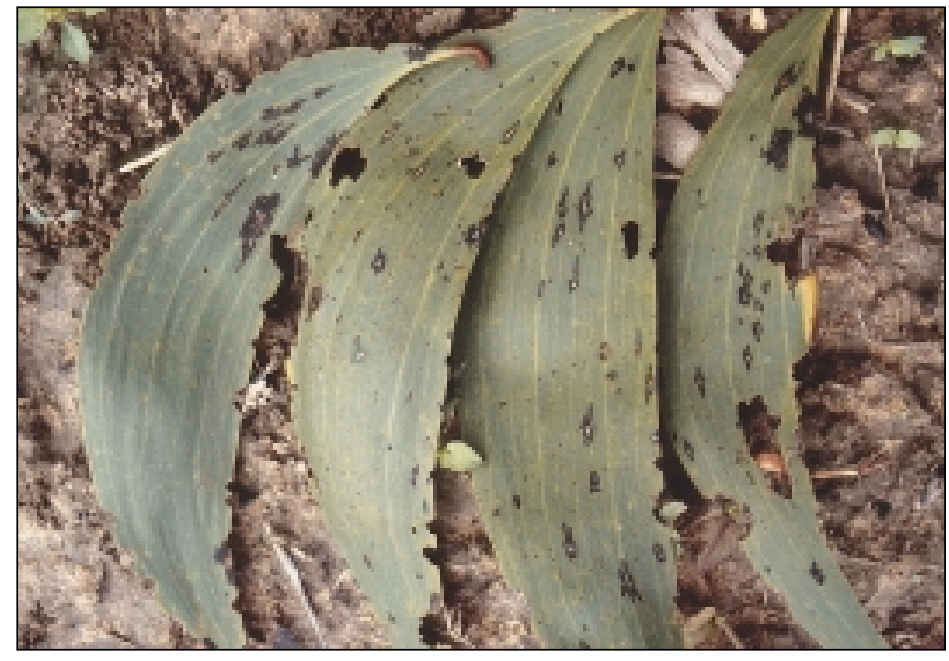

Fig. 42

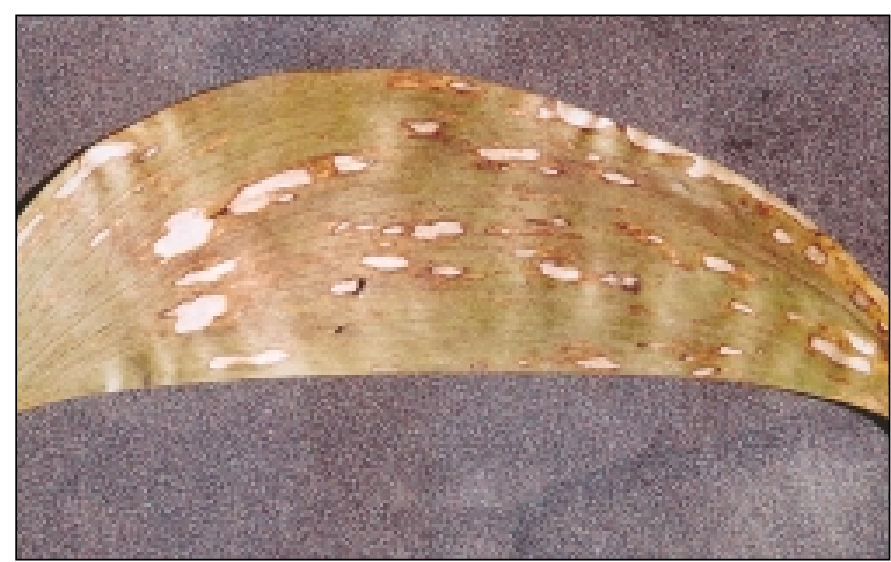

Fig. 43

Fig. 41 Lesions caused by Colletotrichum sp. on Acacia auriculiformis (India) Fig. 42 Lesions caused by Colletotrichum sp. on A. aulacocarpa (Thailand) Fig. 43 Lesions caused by Colletotrichum sp. on A. crassicarpa (India) 


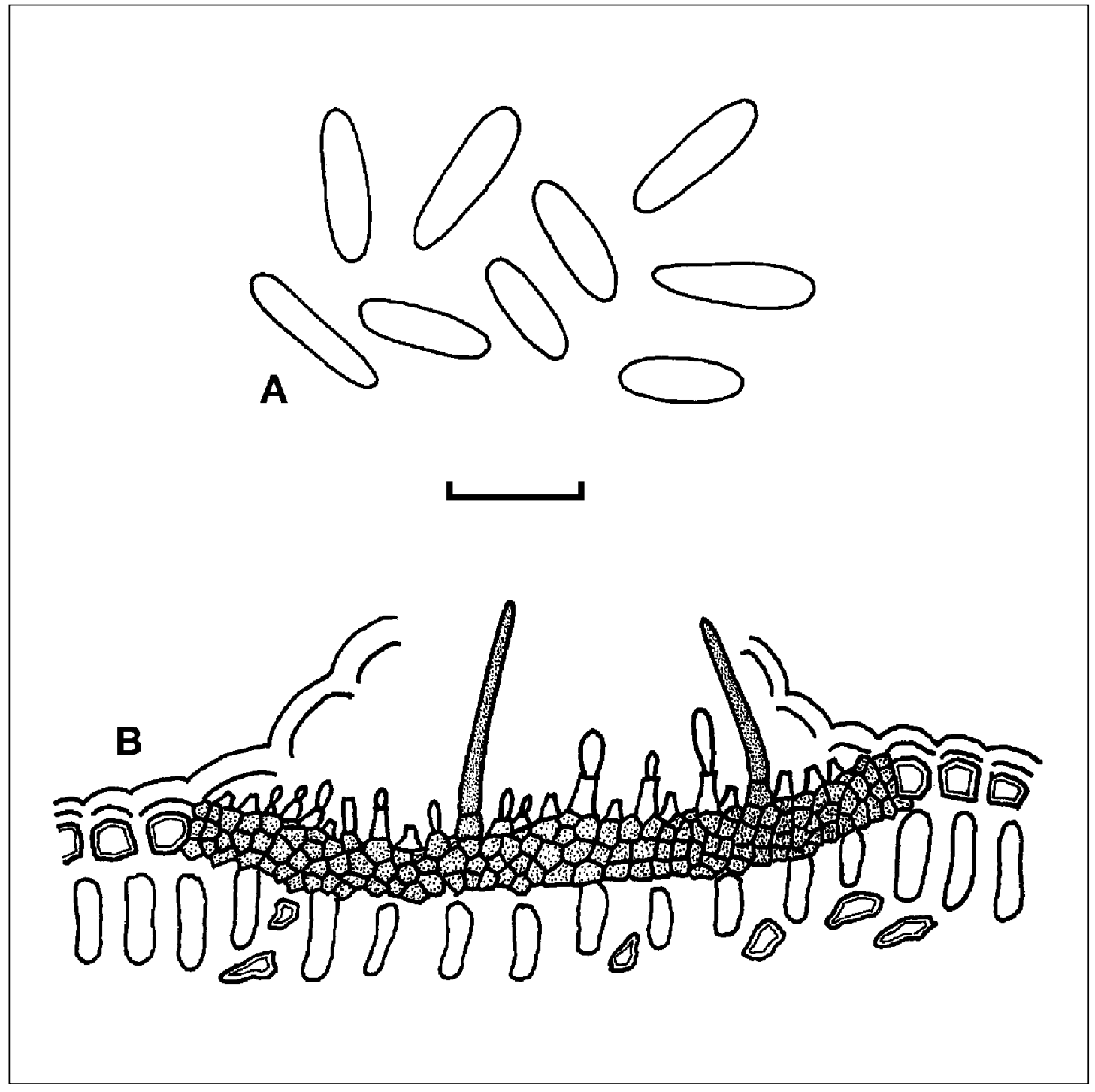

Fig. 44

Fig. 44 Colletotrichum sp. on Acacia aulacocarpa
A. Conidia
$\mathrm{B}$. Longitudinal section of fruiting structure showing conidiophores and setae
(Bar $=20 \mu \mathrm{m}$ for $\mathrm{A} ;=50 \mu \mathrm{m}$ for $\mathrm{B}$ ) 


\section{PESTALOTIOPSIS FOLIAR SPOT}

\section{Disease}

Leaf spot, leaf necrosis

\section{Causal organisms}

Pestalotiopsis spp. Identification of this group of fungi is based on the characteristic five-celled spores. The three central cells are pigmented in various shades of brown and the terminal cells are free of pigment. The basal cell is typically conical with a short simple appendage whereas the apical cell bears two or three appendages reminiscent of a mediaeval jester's cap. Species identified on tropical acacias include P. acaciae and P. neglecta (Fig. 48).

\section{Host range}

Pestalotiopsis spp. are found on scattered spots or more extensive necrotic areas on Acacia aulacocarpa, A. auriculiformis, A. crassicarpa and A. mangium. Fungi belonging to this genus are commonly associated with angular leaf spots of forest and fruit trees (Kobayashi and de Guzman 1988). They are readily isolated from seed of acacias and other tree species (Yuan et al. 1990), and occur as saprophytes on seedlings and exposed sapwood of larger trees after wounding.

\section{Known distribution}

Symptoms associated with infection of phyllodes of tropical acacias by Pestalotiopsis spp. have been found in Australia, including Queensland (Old et al. 1997) and the Northern Territory (Yuan 1996), and in India on all the four acacia species listed above (Sharma and Florence 1997). Collections have also been made in Sumatra, Kalimantan, Sarawak and in south-east Vietnam (Old, unpublished). The collections have not been identified to species except in a few cases (Yuan 1996).

\section{Symptoms}

Symptoms vary greatly on living phyllodes, and include small, scattered dark-brown or reddish-brown, discrete spots, sometimes with a bleached central region (Fig. 45). The characteristic spores, easily recognised with a light microscope (Fig. 48), are produced on black, saucer-shaped fungal stromata (acervuli) which erupt through the epidermis and release conidia onto the leaf surface.

Fruiting bodies of Pestalotiopsis spp. can also be found on larger necrotic lesions often coalescing toward the phyllode tip (Figs 46-47). Depending on species, the conidial masses may be scattered on the lesion surfaces, or be densely aggregated in rows along the veins. 


\section{Pathology}

These fungi are best regarded as minor pathogens and are probably successful saprophytes on dead plant tissue for much of the time. They are often endophytic in healthy leaf tissue and appear only when trees are stressed and leaves become senescent. In plantations, leaf spots are often found on lower parts of the crowns of vigorous trees. In nurseries, where seedlings are densely grown, occasional plants develop many spots or larger necrotic areas on which these fungi sporulate. Where plants are raised from cuttings, unthrifty individuals with necrotic shoots often bear lesions on which Pestalotiopsis can be found. It seems likely that seedlings with severe symptoms (Fig. 47) have been stressed in some way, possibly by drought or by water-logging. Invasion of phyllodes by these fungi is secondary.

\section{Impacts}

Disease surveys in Australia, Indonesia, Malaysia, Vietnam and Thailand suggest that the impact of Pestalotiopsis spp. is small. Nevertheless the fungi are worthy of mention in the context of this manual as symptoms on individual plants, especially seedlings, can be severe and are often noticed by nursery managers.

\section{Control and management}

No control measures are warranted apart from good nursery practice and the avoidance of seedling stress in the nursery and when transporting seedlings or plants derived from cuttings to the field for out-planting.

\section{References}

Kobayashi, T. and Guzman, E.D. de 1988. Monograph of Tree Diseases in the Philippines with Taxonomic Notes on their Associated Microorganisms. Forestry and Forest Products Research Institute, Ibaraki, Japan. Bulletin No. 351, 200 p.

Old, K.M., Hood, I.A. and Yuan, Z.Q. 1997. Diseases of tropical acacias in northern Queensland. In: Old, K.M., Lee, S.S. and Sharma, J.K. eds. Diseases of Tropical Acacias. Proceedings of an international workshop, Subanjeriji (South Sumatra), 28 April - 3 May 1996. CIFOR Special Publication, 1-22.

Sharma, J.K. and Florence, E.J.M. 1997. Fungal pathogens as a potential threat to tropical acacias: case study of India. In: Old, K.M., Lee, S.S. and Sharma, J.K. eds. Diseases of Tropical Acacias. Proceedings of an international workshop, Subanjeriji (South Sumatra), 28 April - 3 May 1996. CIFOR Special Publication, 70-107.

Yuan, Z.Q. 1996. Fungi and associated tree diseases in Melville Island, Northern Territory, Australia. Australian Systematic Botany 9: 337-360.

Yuan Z.Q., Old, K.M. and Midgley, S.J. 1990. Investigation of mycoflora and pathology of fungi present on stored seeds of Australian trees. In: Turnbull, J.W. ed. Tropical Tree Seed Research. ACIAR Proceedings No. 28, 103-110. 


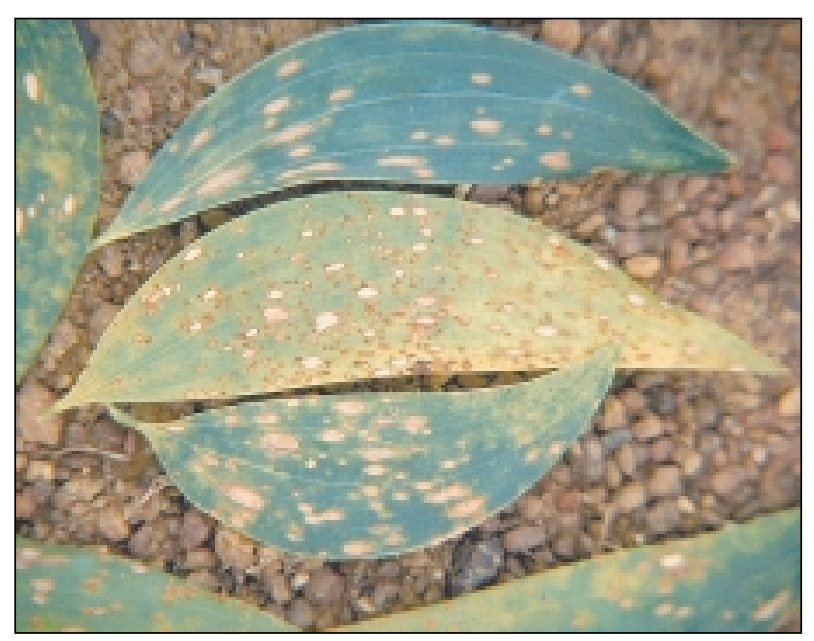

Fig. 45

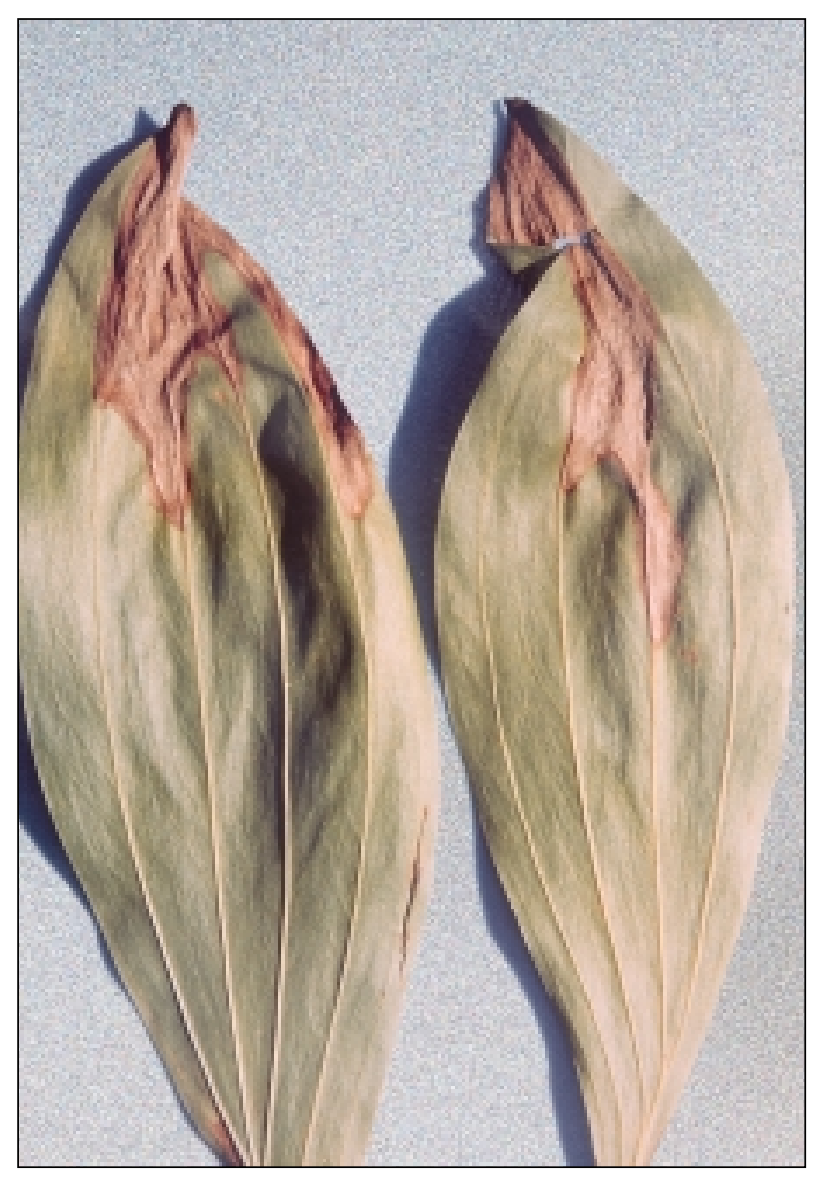

Fig. 47

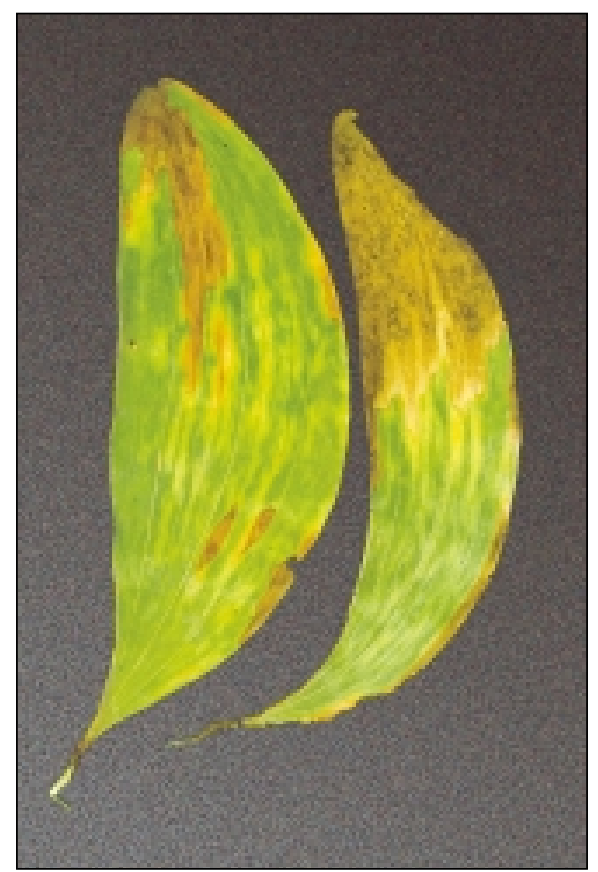

Fig. 46

Fig. 45 Lesions caused by Pestalotiopsis acaciae on Acacia crassicarpa (north Queensland, Australia) Fig. 46 Lesions caused by P. neglecta on A. crassicarpa (Northern Territory, Australia) Fig. 47 Lesions caused by Pestalotiopsis sp. on A. mangium (India) 


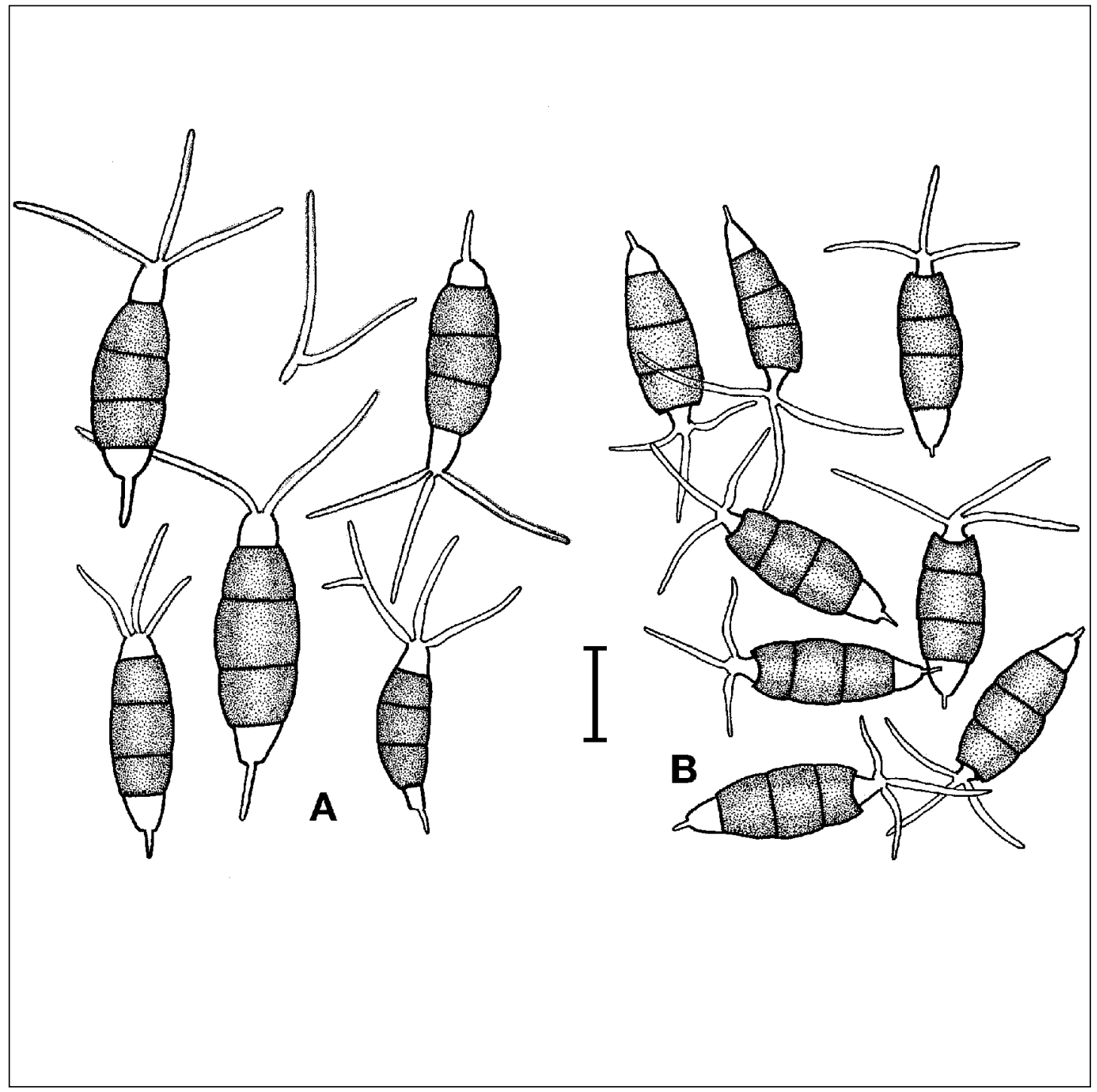

Fig. 48

Fig. 48 Pestalotiopsis spp. on Acacia crassicarpa
A. Conidia of $P$. neglecta
B. Conidia of $P$. acaciae
(Bar $=10 \mu \mathrm{m}$ for $\mathrm{A}$ and $\mathrm{B}$ ) 


\section{PHOMOPSIS FOLIAR SPOT}

\section{Disease}

Phomopsis foliar spot

\section{Causal organisms}

Phomopsis spp. These fungi are imperfect states of the genus Diaporthe which includes many pathogenic species attacking woody plants and other hosts. Phomopsis is the most commonly found state of these fungi, including those associated with diseases of acacias (Sharma et al. 1985).

\section{Host range}

Phomopsis spp. are found on a wide range of host plants, including acacias and other tropical plantation species. They are commonly associated with leaf spots and stem cankers of woody hosts. Diaporthe eres Nitschke, a fungus with a very wide host range on woody species, was found by Kobayashi and de Guzman (1988) associated with a serious stem canker of Acacia auriculiformis in the Philippines. Foliar spot of young nursery seedlings and 15-year-old trees of A. auriculiformis caused by Phomopsis sp. was recorded from India (Mohanan and Sharma 1988) and a Phomopsis sp. was associated with stem cankers of A. auriculiformis and A. mangium in Kalimantan (Hadi and Nuhamara 1997). No teleomorph was observed in these cases. Foliar infection of A. aulacocarpa and A. crassicarpa by Phomopsis sp. has also been recorded in India (Sharma and Florence 1996).

\section{Known distribution}

Foliar infection by Phomopsis sp. has been reported on A. auriculiformis, A. aulococarpa and A. crassicarpa from India (Sharma and Florence 1996) and on A. mangium in natural stands in Australia (Old et al. 1997). Phomopsis sp. was also found associated with seedling diseases of Acacia in Thailand (Pongpanich 1997).

\section{Symptoms}

Foliar spot disease of $A$. auriculiformis caused by this pathogen affects younger phyllodes. The disease initially forms $2-3 \mathrm{~cm}$ long, dark-reddish brown necrotic lesions, later coalescing to form large, pale necrotic lesions which can extend the full length of the phyllode (Fig. 49). Symptoms of disease on A. crassicarpa (Fig. 50) and A. aulacocarpa (Fig. 51) are similar, being characterised by light-coloured, necrotic areas with irregular, raised and well demarcated dark-brown margins (Fig. 51). The lesions gradually spread down the laminae and occasionally cover up to half the phyllode. Pycnidia develop as minute greyish-black dots within these necrotic areas and produce two types of conidia: $\alpha$-conidia and $\beta$-conidia (Fig. 52). 


\section{Pathology and impact}

No systematic studies of this disease have yet been conducted as surveys in India, Australia and Thailand suggest that foliar disease associated with Phomopsis sp. is not important. In India, where A. auriculiformis suffered moderate damage, infected phyllodes were shed prematurely. Phomopsis spp. found associated with canker symptoms are best regarded as secondary, opportunist pathogens.

\section{Control and management}

There is no information available on control measures for phomopsis foliar spot in acacias. Similar diseases of other tree species in forest nurseries have been controlled using mancozeb and carbendazim fungicides. In common with other opportunist canker pathogens, disease can be avoided by matching species and provenances to site conditions as trees under stress from drought (Kobayashi and de Guzman 1988) or biotic agents are most prone to infection by these fungi.

\section{References}

Hadi, S. and Nuhamara, S.T. 1997. Diseases of species and provenances of acacias in West and South Kalimatan, Indonesia. In: Old, K.M., Lee, S.S. and Sharma, J.K. eds. Diseases of Tropical Acacias. Proceedings of an international workshop, Subanjeriji (South Sumatra), 28 April - 3 May 1996. CIFOR Special Publication, 23-47.

Kobayashi, T. and Guzman, E.D. de 1988. Monograph of Tree Diseases in the Philippines with Taxonomical Notes on their Associated Microorganisms. Forestry and Forest Products Research Institute Ibaraki, Japan. Bulletin No. 351, 200 p.

Mohanan, C. \& Sharma, J.K. 1988. Diseases of exotic acacias in India. Journal of Tropical Forestry 4: 357-361.

Old, K.M., Hood, I.A. and Yuan, Z.Q. 1997. Diseases of tropical acacias in northern Queensland. In: Old, K.M., Lee, S.S. and Sharma, J.K. eds. Diseases of Tropical Acacias. Proceedings of an international workshop, Subanjeriji (South Sumatra), 28 April - 3 May 1996. CIFOR Special Publication, 1-22.

Pongpanich, K. 1997. Diseases of Acacia sp. in Thailand. In: Old, K.M., Lee, S.S. and Sharma, J.K. eds. Diseases of Tropical Acacias. Proceedings of an international workshop, Subanjeriji (South Sumatra), 28 April - 3 May 1996. CIFOR Special Publication, 62-67.

Sharma, J.K., Mohanan, C. and Florence, E.J.M. 1985. Disease survey in nurseries and plantations of forest tree species grown in Kerala. Kerala Forest Research Institute Research Report No. 85, 268 p.

Sharma, J.K. and Florence, E.J.M. 1996. Fungal pathogens as a threat to tropical acacias - A case study of India. Kerala Forest Research Institute Research Report No. 113, 44 p. 

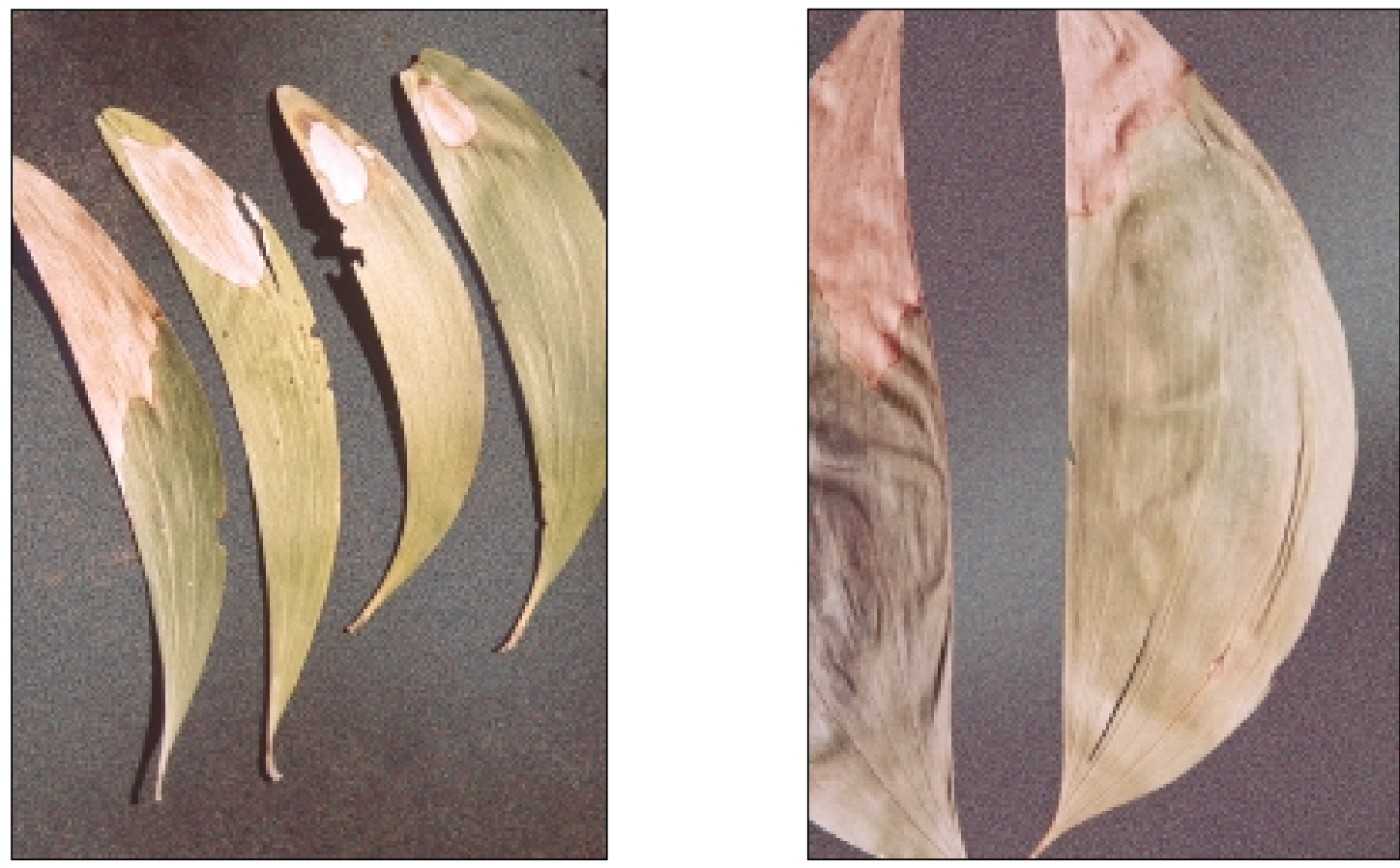

Fig. 49

Fig. 50

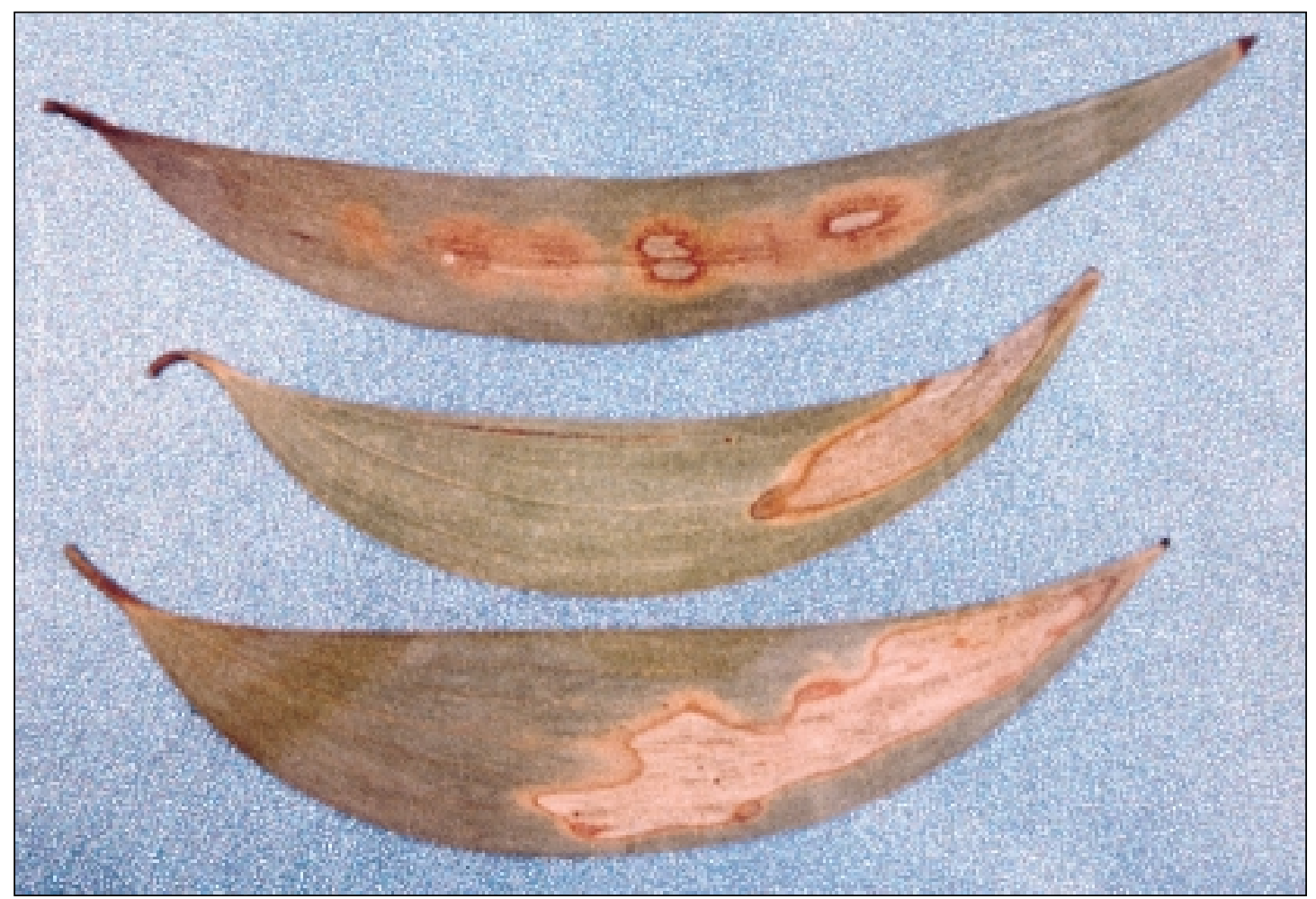

Fig. 51

Fig. 49 Lesions caused by Phomopsis sp. on Acacia auriculiformis (India)

Fig. 50 Lesions caused by Phomopsis sp. on A. mangium (India)

Fig. 51 Lesions caused by Phomopsis sp. on A. aulacocarpa (India) 

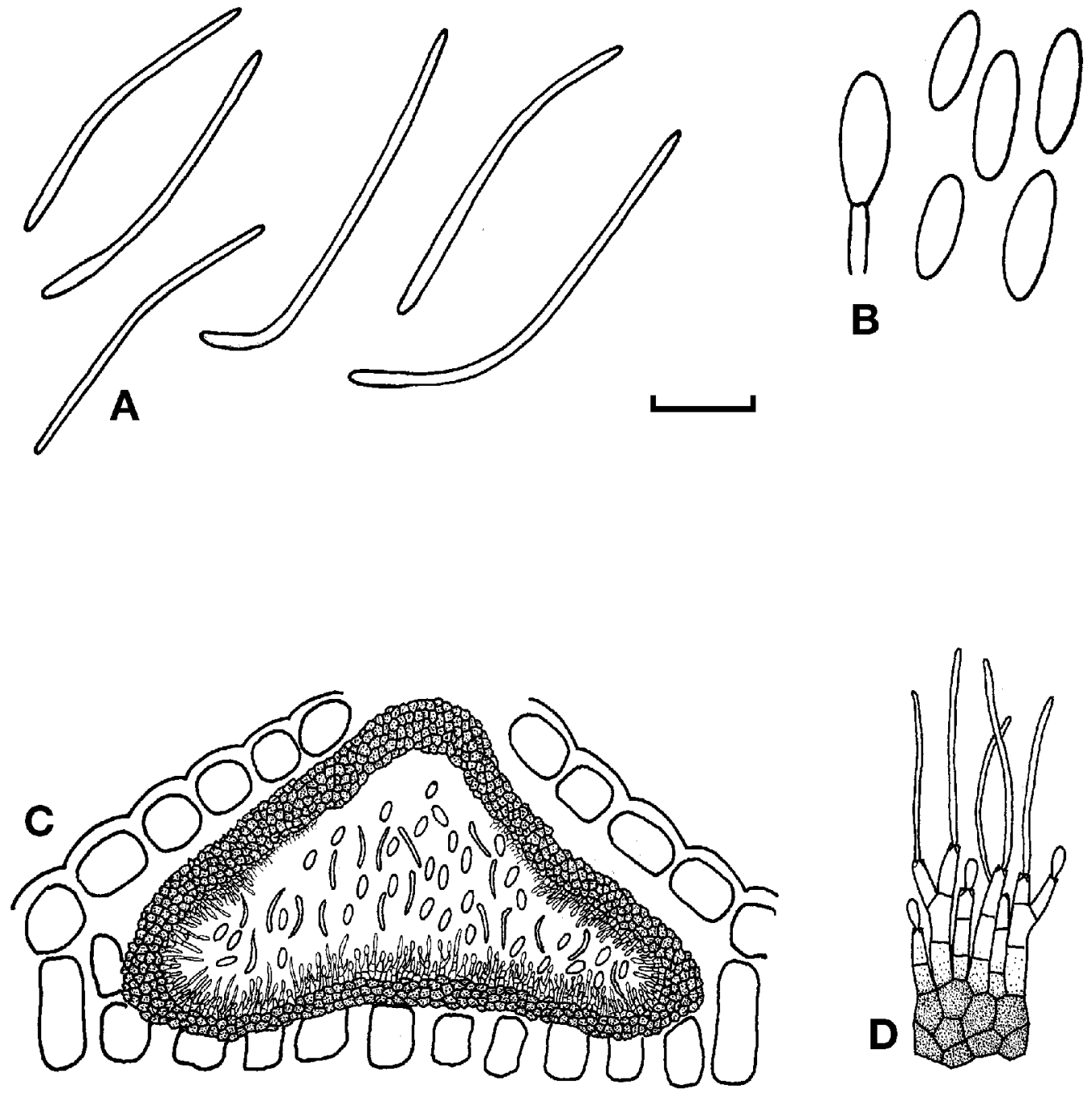

Fig. 52

Fig. 52 Phomopsis sp.
A. Beta conidia
B. Alpha conidia
C. Longitudinal section of fruiting body embedded in phyllode surface
D. Conidiophores and developing conidia
$(\mathrm{Bar}=5 \mu \mathrm{m}$ for $\mathrm{A}$ and $\mathrm{B} ;=100 \mu \mathrm{m}$ for $\mathrm{C} ;=10 \mu \mathrm{m}$ for $\mathrm{D})$ 


\section{PHYLLOSTICTA FOLIAR BLOTCH}

\section{Disease}

Phyllosticta foliar blotch

\section{Causal organism}

Phyllosticta sp. and its teleomorph Guignardia sp.

\section{Host range}

Guignardia spp. are well known foliar pathogens of broad-leaved trees e.g. G. aesculi (Peck) V. B. Stewart (Punithalingam 1993), conifers (Bissett and Palm 1989; Kobayashi and Sasaki 1975), and herbaceous plants. Although there are records on several tree species grown in the tropics, e.g. Gmelina arborea (Kobayashi and de Guzman 1988) and Castanopsis (Hsieh et al. 1997), the surveys undertaken in northern Australia and Indonesia in 1996 (Old et al. 1997) provided the first records of this pathogen on plantation acacias. Cannon et al. (1997) examined the specimens from Australia and Indonesia but were unable to determine whether one or two species were present. In view of the capacity of some members of this genus to cause severe disease on tree hosts the fungus has been included in this manual.

\section{Known distribution}

A yet-undetermined species of Guignardia and its Phyllosticta anamorph was collected on Acacia mangium in South Sumatra. The collection on A. aulacocarpa in north Queensland bore only the Phyllosticta anamorph. Cannon et al. (1997) commented that there are other collections of Guignardia on Acacia spp. in Australian herbaria and recommended study of these to gain some idea of the distribution of the pathogen.

\section{Symptoms}

Symptoms are shown on both known acacia hosts, A. aulacocarpa and A. mangium, in Figs 53-54. The symptoms are somewhat similar to foliar disease associated with infection by Pestalotiopsis neglecta (Fig. 46), but the darkly pigmented pycnidia contain small, colourless, spheroidal conidia (Fig. 55), each with a mucilaginous sheath. The pigmented teleomorph (perithecium) is embedded in the phyllode and contains sac-like asci with eight ascospores bearing characteristic apical appendages (Fig. 55).

\section{Pathology and impacts}

There is not sufficient information on Guignardia on acacias to judge whether the pathogen has the capacity to cause significant disease. The two collections made so far have been on 
young trees in a nursery (A. aulacocarpa in Queensland) and on recently out-planted trees (A. mangium in Sumatra). Individual phyllodes were severely affected but damage at the whole-tree level was minor.

\section{References}

Bissett, J. and Palm, M.E. 1989. Species of Phyllosticta on conifers. Canadian Journal of Botany 67: 3378-3385.

Cannon, P., Pascoe, I., Beilharz, V. and Yuan, Z.Q. 1997. Report on fungi from diseased Acacia samples examined at Institute of Horticultural Development, Knoxfield. In: Old, K.M., Lee, S.S. and Sharma, J.K. eds. Diseases of Tropical Acacias. Proceedings of an international workshop, Subanjeriji (South Sumatra), 28 April - 3 May 1996. CIFOR Special Publication, 108-113.

Hsieh, W.H., Chen, C.Y. and Sivanesan, A. 1997. Some new ascomycetes from Taiwan. Mycological Research 101: 897-907.

Kobayashi, T. and Guzman, E.D. de 1988. Monograph of Tree Diseases in the Philippines with Taxonomic Notes on their Associated Microorganisms. Forestry and Forest Products Research Institute, Ibaraki, Japan. Bulletin No. 351, 200 p.

Kobayashi, T. and Sasaki, K. 1975. Notes on new or little-known fungi inhabiting woody plants in Japan. VII. Transactions of the Mycological Society of Japan 16: 230-244.

Old, K.M., Hood, I.A. and Yuan, Z.Q. 1997. Diseases of tropical acacias in northern Queensland. In: Old, K.M., Lee, S.S. and Sharma, J.K. eds. Diseases of Tropical Acacias. Proceedings of an international workshop, Subanjeriji (South Sumatra), 28 April - 3 May 1996. CIFOR Special Publication, 1-22.

Punithalingam, E. 1993. Guignardia aesculi. I.M.I. Descriptions of Fungi and Bacteria. No. 1165. International Mycological Institute, Egham, England, 2 p. 


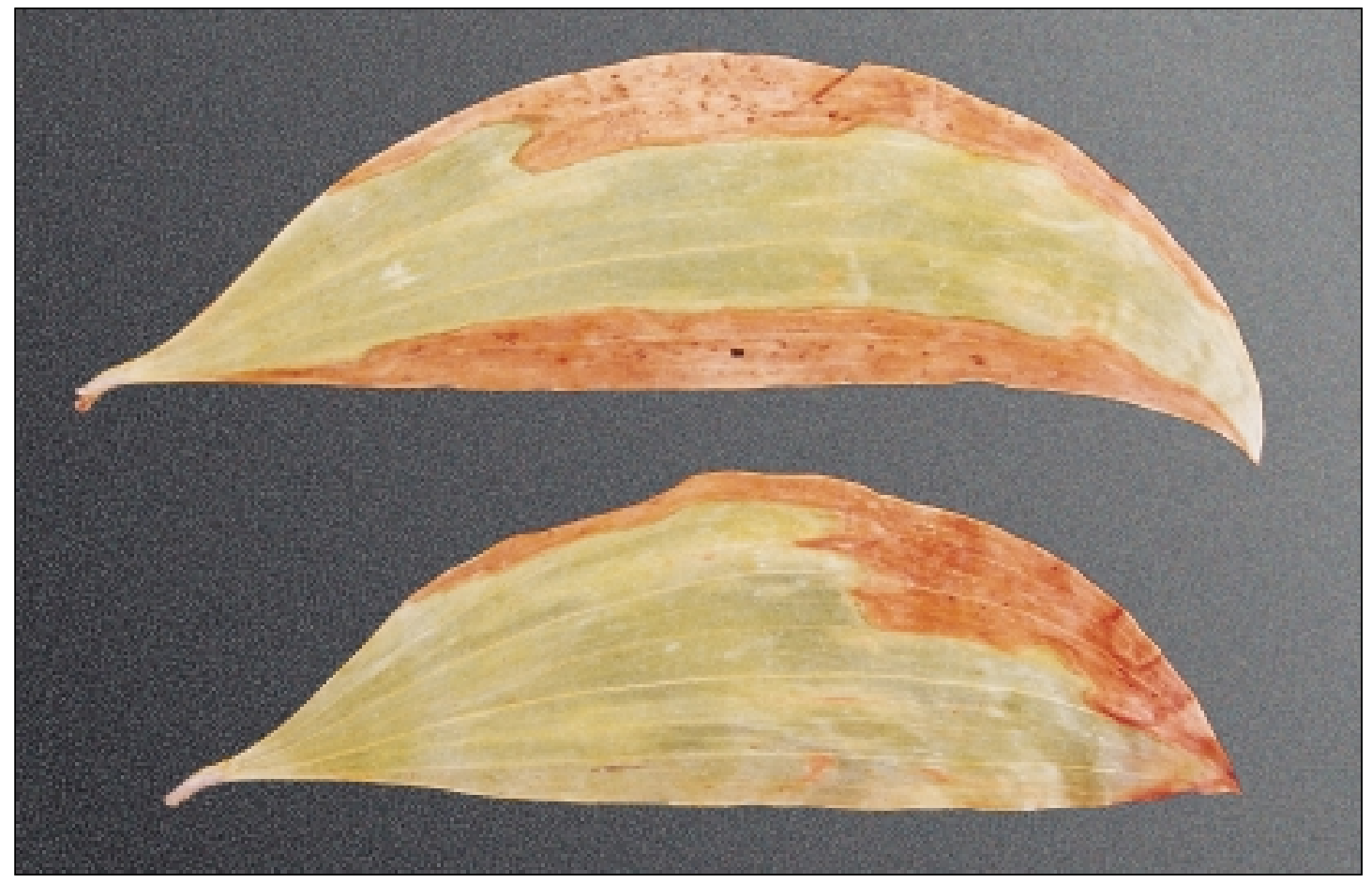

Fig. 53

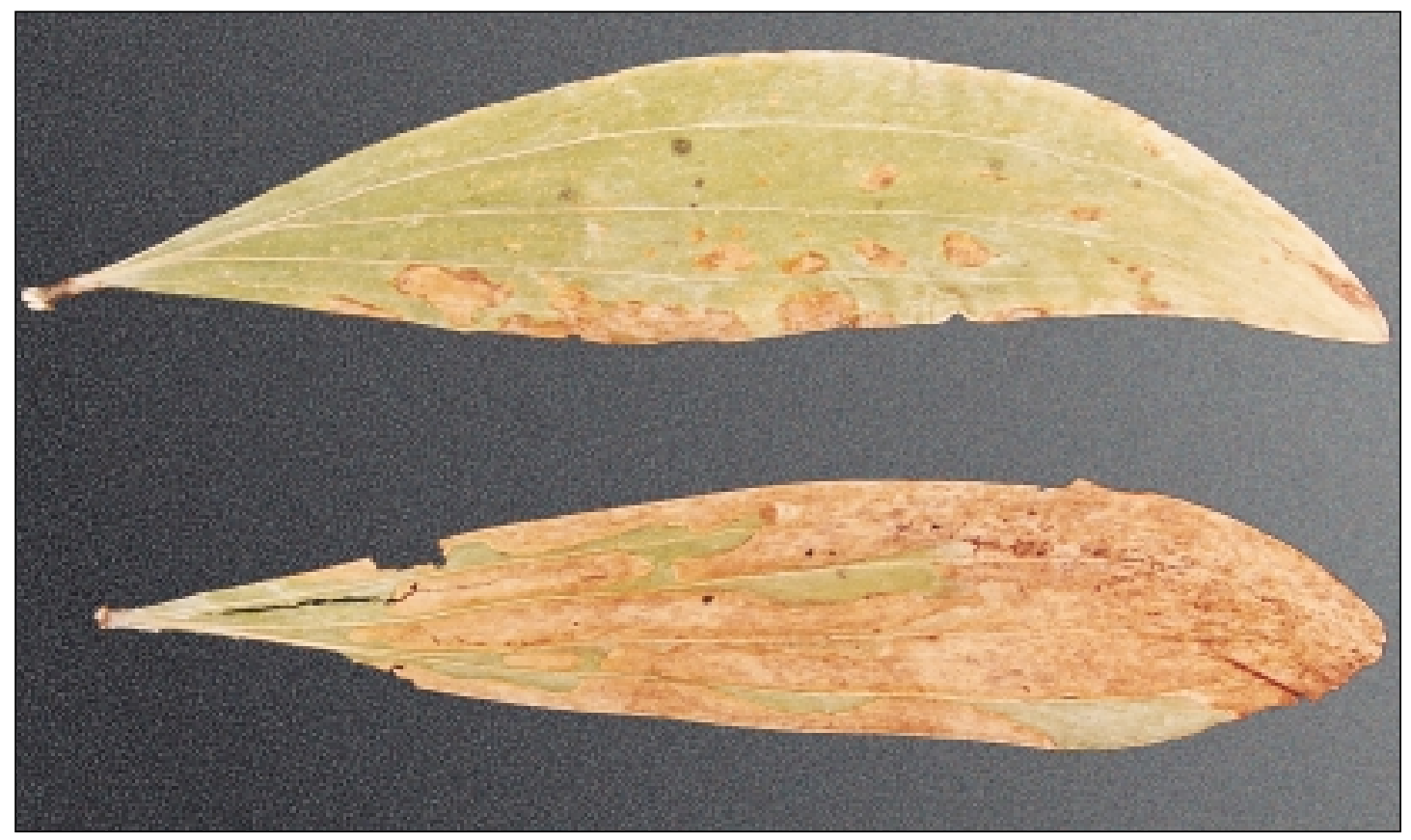

Fig. 54

Fig. 53 Lesions caused by Phyllosticta sp. on Acacia aulacocarpa (north Queensland, Australia) Fig. 54 Lesions caused by Phyllosticta sp. on A. mangium (Sumatra) 

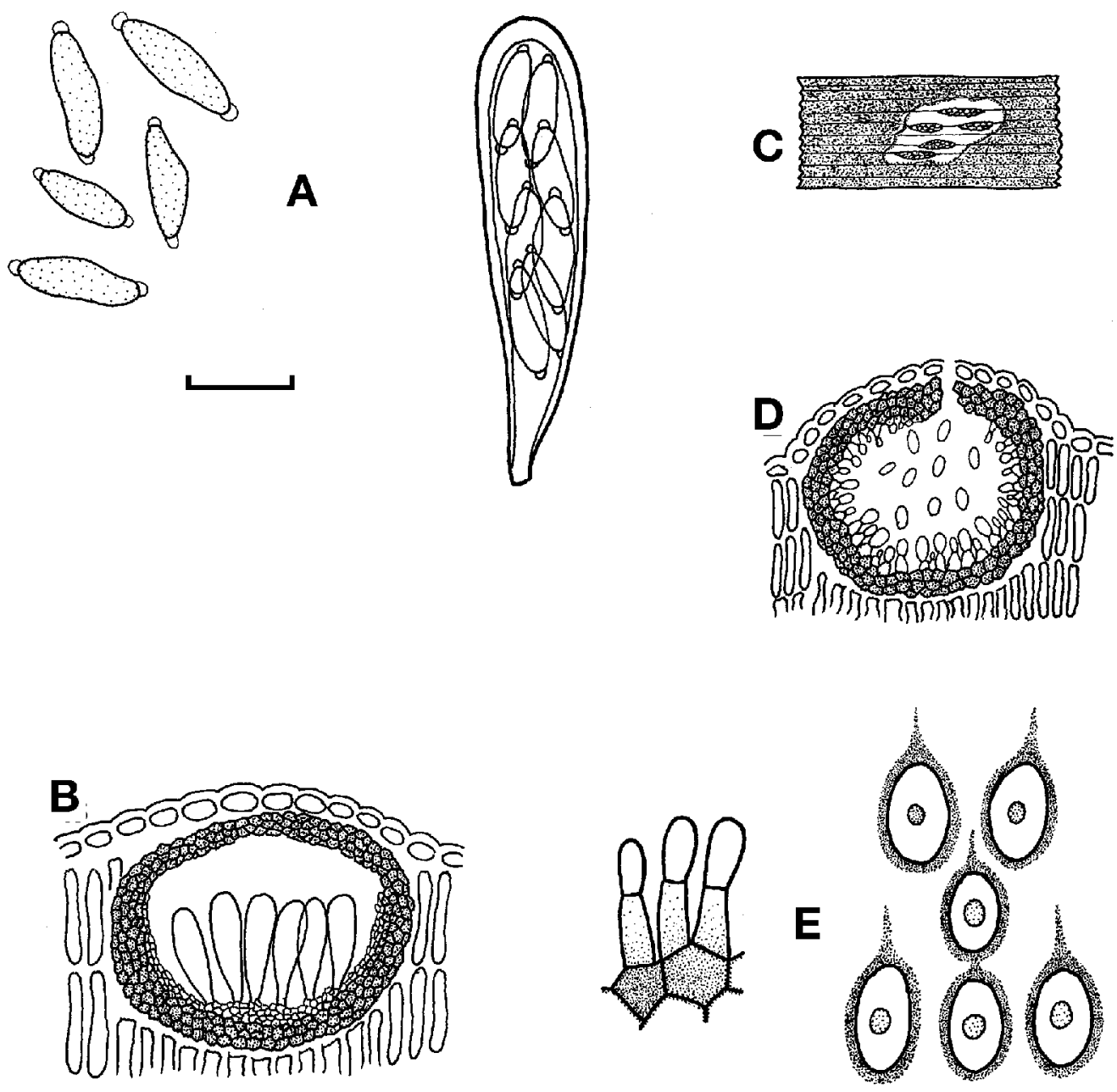

Fig. 55

Fig. 55 Guignardia sp. and Phyllosticta sp.

A. Ascospores and ascus of Guignardia sp. on Acacia mangium

B. Longitudinal section of fruiting structure of Guignardia sp.

C. Portion of a phyllode with lesion, bearing aggregated fruiting bodies of Phyllosticta sp.

on A. aulacocarpa

D. Longitudinal section of fruiting body of Phyllosticta

E. Conidia and conidiophores of Phyllosticta

$(\mathrm{Bar}=25 \mu \mathrm{m}$ for $\mathrm{A} ;=50 \mu \mathrm{m}$ for $\mathrm{B}$ and $\mathrm{D} ;=10 \mu \mathrm{m}$ for $\mathrm{E}$; not to scale for $\mathrm{B})$ 


\section{PINK DISEASE}

\section{Disease}

Pink disease, cendawan angin (Bahasa Malaysia), jamur upas (Bahasa Indonesia)

\section{Causal organism}

Corticium salmonicolor Berk. \& Br. (syn. Pellicularia salmonicolor (Berk. \& Br.) Dastur).

\section{Host range}

The fungus is an obligate parasite of numerous woody plants ranging from forest to fruit trees. It has also been recorded on many tropical crops such as cacao, coffee, tea, ramie, rubber (Fig. 60) and many forest plantation trees (Browne 1968).

\section{Known distribution}

The fungus is widely distributed in the tropics, sub-tropics and warmer parts of the temperate region. Pink disease is primarily a disease of the stem and branches. The pathogen infects and kills living bark tissue. Trees of almost any age are attacked.

\section{Symptoms}

Four stages of the fungus are recognised, namely the cobweb, pustule, pink incrustation and necator stages. The first sign of infection is the cobweb stage (Fig. 56) where silky, white mycelia grow over the surface of the bark. This stage occurs soon after the onset of rain (Seth et al. 1978). The pustule stage is readily identifiable when pink pustules consisting of sterile mycelia are produced on the affected area (Fig. 57). The pink incrustation develops late in the disease process and consists of the sexual corticium stage of the fungus. This smooth salmon-pink layer usually develops on the shaded underside of the dying infected branch (Figs 58-59). As this layer ages, it cracks into patches and fades to a dirty white colour. The orange-red necator (conidial) stage is less frequently seen, being produced late in the disease process. These pustules develop on the upper side of infected branches.

Apart from the different developmental stages of the fungus on the bark and stem of the infected trees, there are several more noticeable subsidiary symptoms. The foliage on infected branches wilts and subsequently dies, turning brown but remaining attached to the branch for some time. Infected branches often die, resulting in progressive crown dieback, but green epicormic shoots may develop from lateral dormant buds (Fig. 57). Where infection is localised, death and shedding of limited areas of bark may lead to the development of open wounds or cankers. In cases of severe infection or of susceptible hosts, the whole tree may be killed. 


\section{Pathology}

Pink disease is prevalent in areas of high rainfall and during the wet season. The disease is spread by both the basidiospores (Fig. 62) and the conidia of the necator stage which are dispersed by wind. Sporulation and germination of the spores are favoured by moist conditions. The fungus usually infects stems and branches through healthy, intact bark (Fig. 60), thereafter attacking and killing the cambium (Seth et al. 1978). Branches readily break (Fig. 61) and whole trees may be killed. An infection that fails to kill a branch may be contained by host defence reactions or remain dormant, becoming active again after a few months with the onset of wet weather. Branches that are not killed by the infection will develop sunken cankers at the point of infection.

The important role of surrounding vegetation as sources of inoculum for the fungus has been recognised in eucalypt plantations in India (Seth et al. 1978). In South Sumatra, Indonesia, the incidence of pink disease on Acacia mangium was found to be higher in stands near villages where infected rubber trees (Fig. 60) were present (Lee Su See, personal observation).

\section{Impact}

Although several species of tropical acacias, including A. auriculiformis, A. crassicarpa and A. mangium (Chin 1990; Lee 1993; Hadi and Nuhamara 1997; Sharma and Florence 1997), are known to be affected by pink disease, the disease is generally considered of little consequence as trees are seldom killed. The main impact is loss of stem form through loss of the leading shoot. Recent studies, however, show that mortality rates can vary, depending probably on host susceptibility and local environmental conditions. In a disease survey of six provenances of A. mangium in South Sumatra, pink disease was found to affect about $2 \%$ of the trees (Zulfiyah and Gales 1997) while up to $80 \%$ incidence was reported from a roadside plantation of A. auriculiformis in India (Sharma and Florence 1997). Comprehensive surveys need to be conducted in tropical acacia plantations to determine the overall incidence and impact of the disease.

\section{Control and management}

In rubber plantations and fruit tree orchards, the disease can be successfully controlled through early recognition of the symptoms followed by prompt application of suitable fungicides. Bordeaux mixture $\left(\mathrm{CuSO}_{4}: \mathrm{CaO}: \mathrm{H}_{2} \mathrm{O}=1: 2: 10\right)$ and a brush-on formulation of tridemorph applied at regular intervals have been shown to be effective in controlling the disease in rubber plantations and mango orchards in Malaysia (Lim and Khoo 1985).

There is, however, little prospect of utilizing chemical control in forest plantations because of the high costs involved. Thus the best strategy for control and management of the disease in forest plantations would be early recognition of the disease followed (if economic to do so) by removal and disposal of infected branches. Experience in rubber plantations has shown that, in the long term, planting of disease-resistant varieties would be the best strategy to prevent the occurrence of the disease. 


\section{References}

Browne, F.G. 1968. Pests and Diseases of Forest Plantation Trees: An Annotated List of the Principal Species Occurring in the British Commonwealth. Clarendon Press, Oxford, $1330 \mathrm{p}$.

Chin, F.H. 1990. Pink disease - its incidence and economic importance in Sarawak, Malaysia. In: Proceedings of the 3rd International Conference on Plant Protection in the Tropics, Vol. IV: 156-160.

Hadi, S. and Nuhamara, S.T. 1997. Diseases of species and provenances of acacias in West and South Kalimantan, Indonesia. In: Old, K.M., Lee, S.S. and Sharma, J.K. eds. Diseases of Tropical Acacias. Proceedings of an international workshop, Subanjeriji (South Sumatra), 28 April - 3 May 1996. CIFOR Special Publication, 23-47.

Lee, S.S. 1993. Diseases. In: Awang, K. and Taylor, D. eds. Acacia mangium - Growing and Utilization. Bangkok, Thailand: Winrock International and FAO. MPTS Monograph Series No. 3: 203-223.

Lim, T.K. \& Khoo, K.C. 1985. Diseases and Disorders of Mango in Malaysia. Tropical Press Sdn. Bhd., 101 p.

Seth, S.K., Bakshi, B.K., Reddy, M.A.R. and Sujan Singh. 1978. Pink disease of Eucalyptus in India. European Journal of Forest Pathology 8: 200-216.

Sharma, J.K. and Florence, E.J.M. 1997. Fungal pathogens as a potential threat to tropical acacias: case study of India. In: Old, K.M., Lee, S.S. and Sharma, J.K. eds. Diseases of Tropical Acacias. Proceedings of an international workshop, Subanjeriji (South Sumatra), 28 April - 3 May 1996. CIFOR Special Publication, 70-107.

Zulfiyah, A. and Gales, K. 1997. Diseases of tropical acacias in South Sumatra. In: Old, K.M., Lee, S.S. and Sharma, J.K. eds. Diseases of Tropical Acacias. Proceedings of an international workshop, Subanjeriji (South Sumatra), 28 April - 3 May 1996. CIFOR Special Publication, 48-52. 

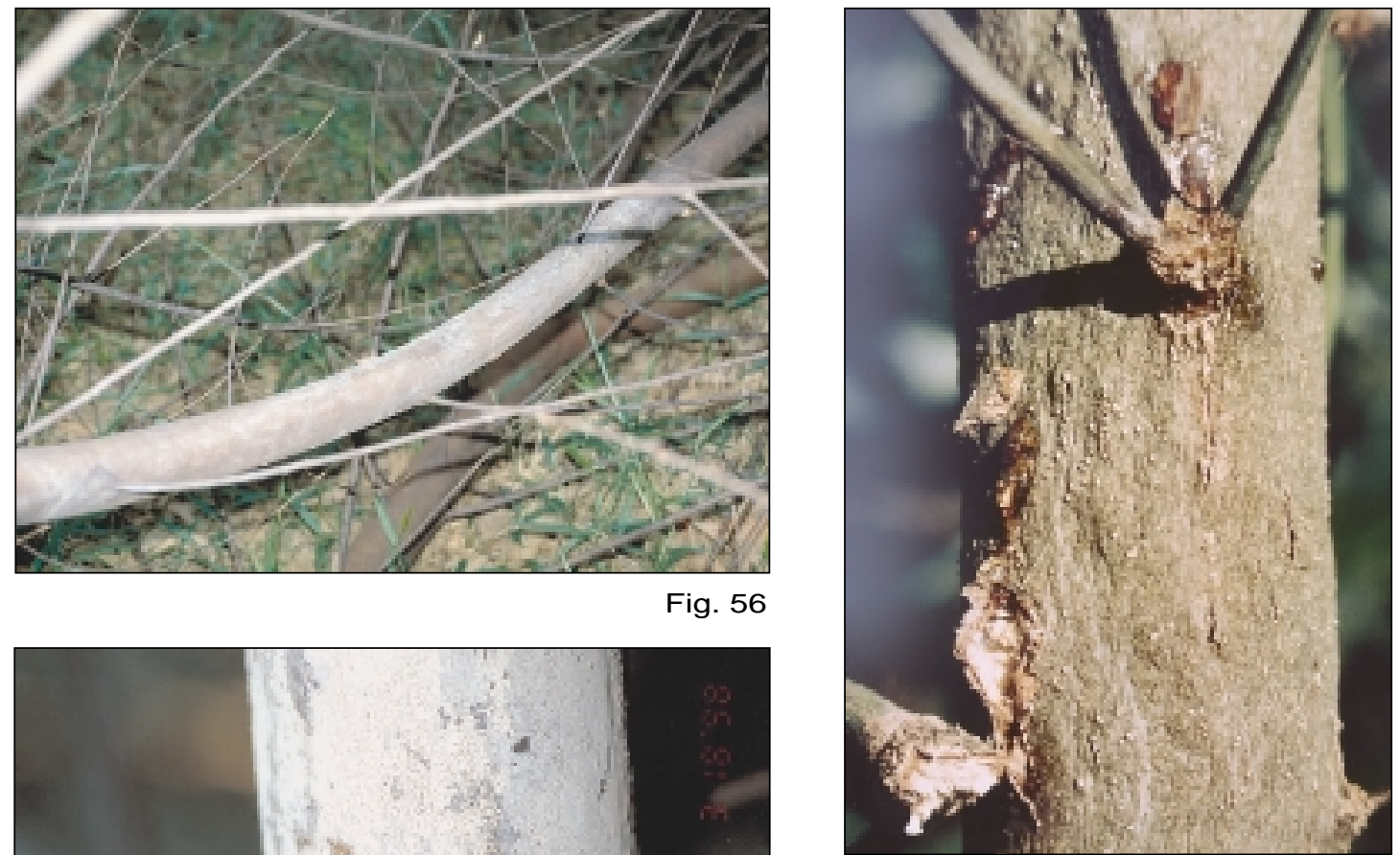

Fig. 56

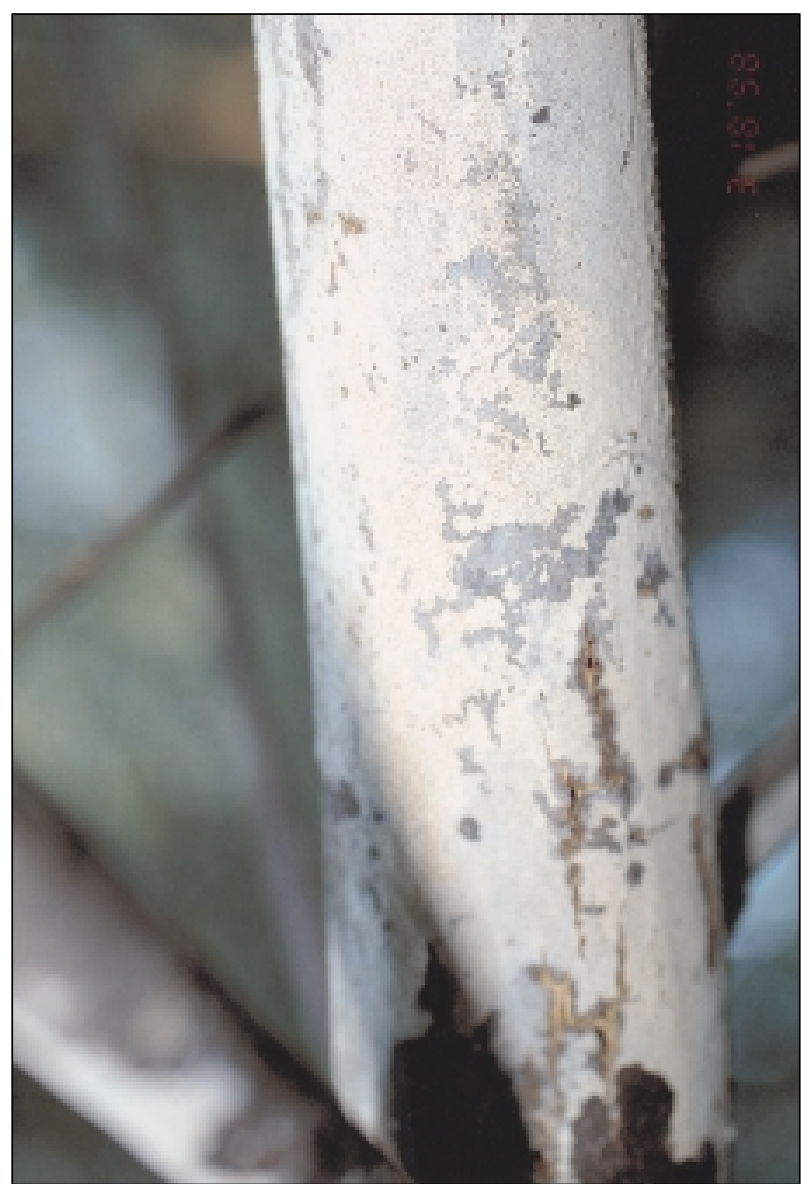

Fig.57

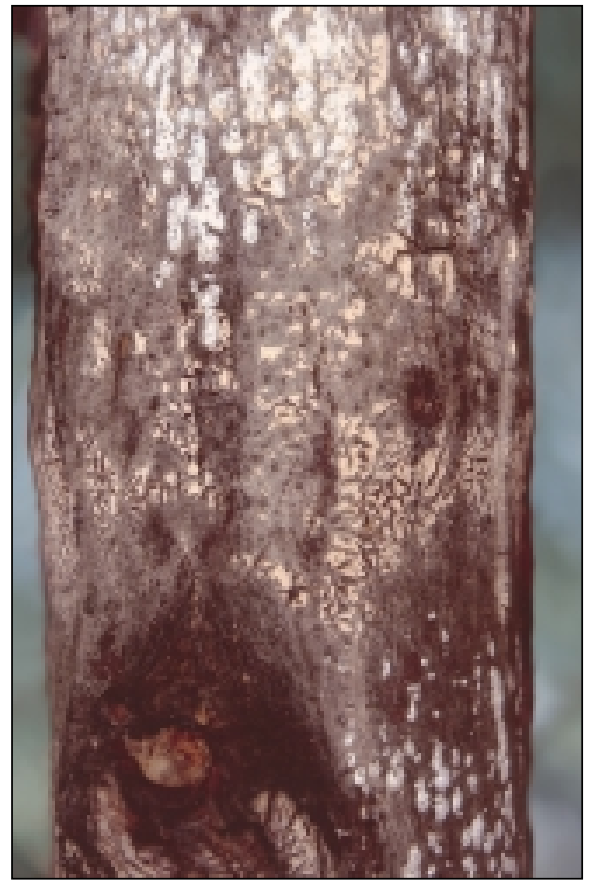

Fig. 58

Fig. 59

Fig. 56 Corticium salmonicolor 'cobweb' stage of infection on Acacia mangium (Sumatra)

Fig. 57 C. salmonicolor 'pustule' stage on A. auriculiformis (India)

Fig. 58 C. salmonicolor, early 'corticium' stage on A. mangium (Sumatra)

Fig. 59 C. salmonicolor, late 'corticium' stage on a dead tree (Sumatra) 


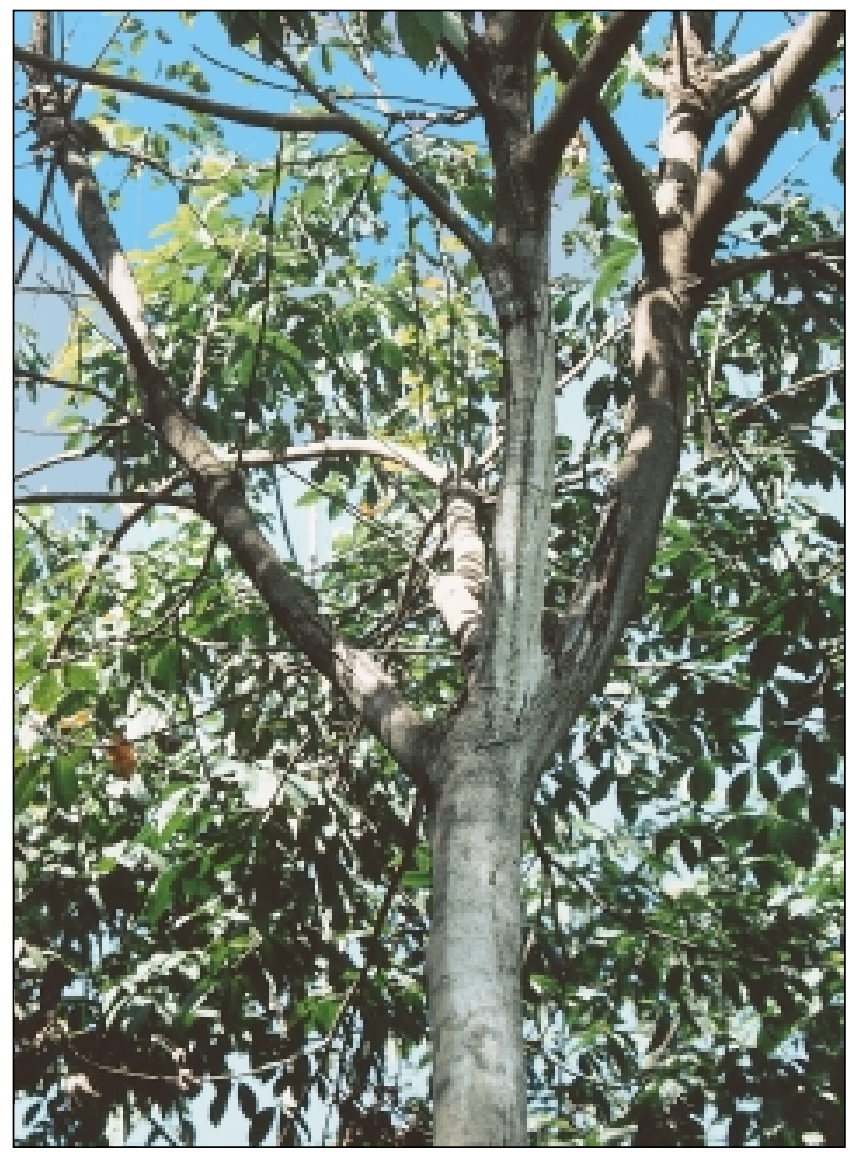

Fig. 60

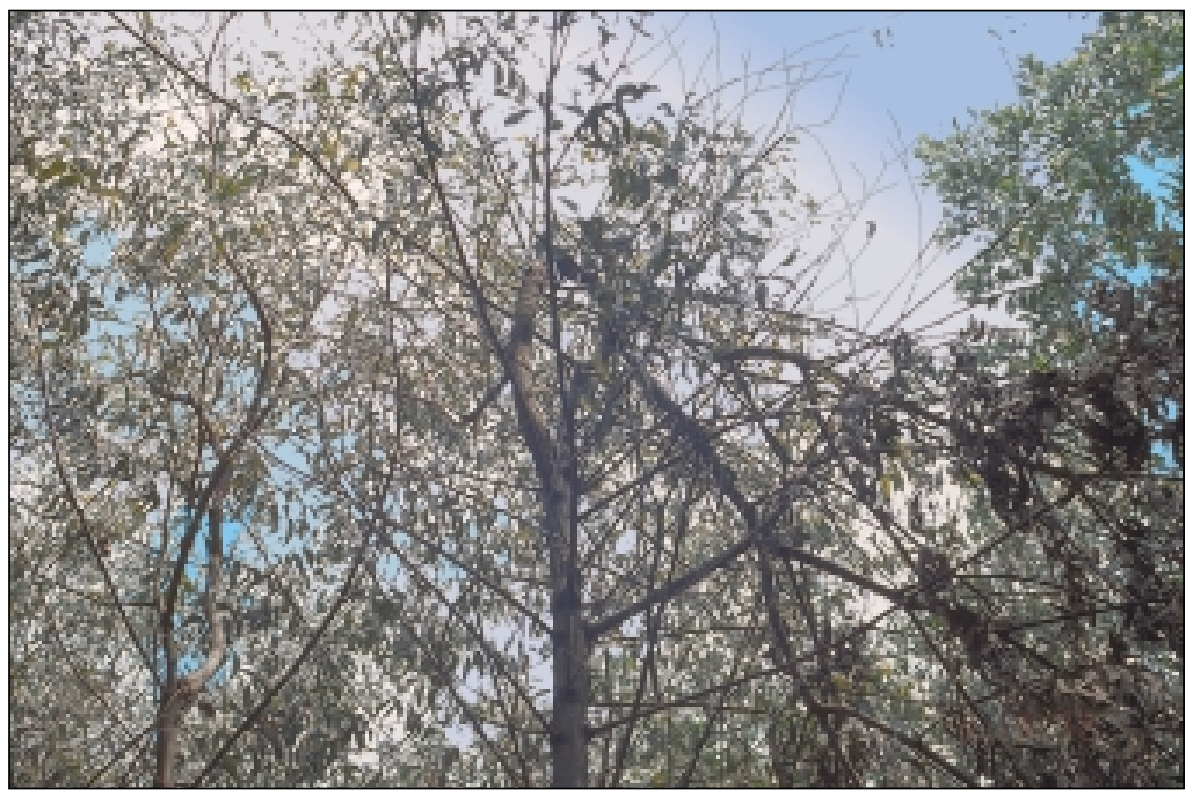

Fig. 61

Fig. 60 C. salmonicolor 'corticium' stage on rubber (Vietnam)

Fig. 61 C. salmonicolor damage showing A. auriculiformis with broken top (Sumatra) 

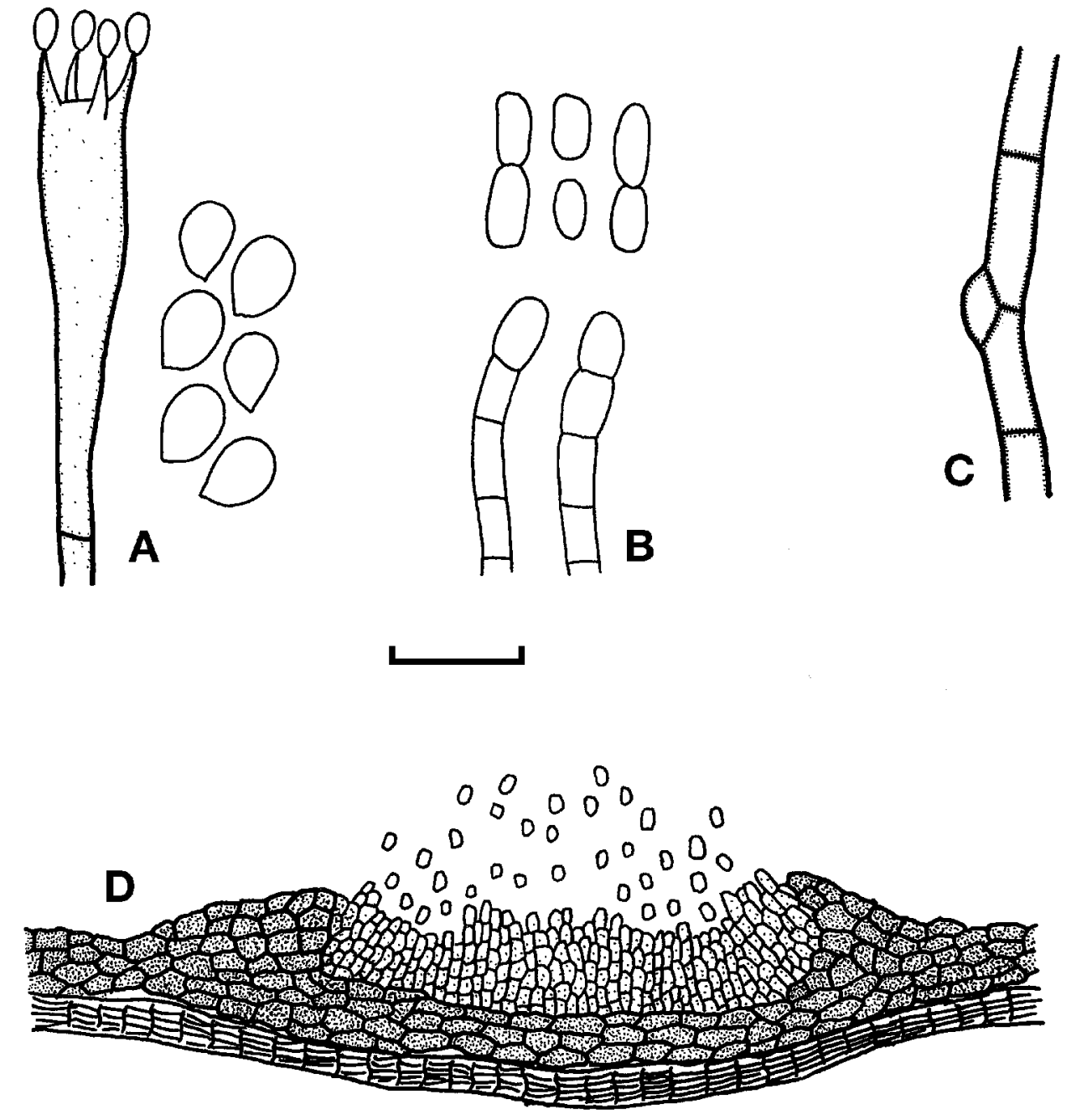

Fig. 62

Fig. 62 Corticium salmonicolor
A. Basidium and basidiospores
B. Conidiogenous cells and conidia
C. Hypha with a 'clamp connection' commonly found in basidiomycete mycelium
D. Longitudinal section of fruiting structure producing conidia
$(\mathrm{Bar}=15 \mu \mathrm{m}$ for $\mathrm{A} ;=20 \mu \mathrm{m}$ for $\mathrm{B}$ and $\mathrm{C} ;=120 \mu \mathrm{m}$ for $\mathrm{D})$ 


\section{STEM AND BRANCH CANKERS}

\section{Disease}

Stem and branch canker, kanker batang dan dahan (Bahasa Malaysia, Bahasa Indonesia)

\section{Causal organisms}

Botryosphaeria spp. and their anamorphs; Lasiodiplodia theobromae (Pat.) Griff. \& Maubl and Dothiorella spp.

Valsa Fr., anamorph Cytospora spp.

Nattrassia mangiferae (H. \& P. Syd.) Sutton \& Dyko (syn. Hendersonula toruloidea Nattrass)

Macrovalsaria megalospora (Mont.)

\section{Host range}

A wide range of trees and woody shrubs, in plantations and native vegetation.

\section{Known distribution}

Botryosphaeria spp. and Valsa spp. are distributed worldwide in tropical and temperate regions (Old et al. 1991; Lenné 1992; Roux and Wingfield 1997), whereas N. mangiferae (Punithalingam and Waterston 1970) and M. megalospora (Sivanesan 1975) are mainly found in the tropics and sub-tropics.

\section{Symptoms}

Cankers are dead areas of bark sometimes with sapwood exposed, or with sunken lesions extending from a few centimetres to more than a metre along branch and stem axes. They may be darkly discolored and cracked especially toward the centre. Branches and stems may be partially or completely girdled, causing crown dieback and possibly tree death. Fruiting bodies of the causal fungi can usually be found on the cankers themselves, especially at the margin between diseased and healthy bark or on newly dead branches. The fruiting bodies are typically partially submerged in the outer bark but can be readily seen through a hand lens. Cankers are often associated with wounds, borer damage or branch stubs.

Identification of the causal agents of cankers is often quite difficult, requiring detailed examination of the sexual (teleomorph) and asexual (anamorph) fruiting structures. In this account three of the species most commonly found on plantation-grown acacias in the tropics are illustrated, with drawings of the structures useful in identification. Fungi associated with cankers span a range of pathogenicity. Botryosphaeria spp. (Figs 63-66, Fig. 71) cause cankers and dieback on many woody species whereas Valsa spp., usually found as the 
anamorphic state Cytospora (Figs 67,72), are often opportunist pathogens with little capacity to invade healthy trees. N. mangiferae is pathogenic on woody tissues of several tree species. It is generally regarded as a weak parasite, invading the cambial region of wide range of hosts following injury (Browne 1968; Gibson 1975; Sharma et al. 1990). Illustrations of this fungus can be found in Punithalingam and Waterston (1970). M. megalospora is commonly found fruiting on dead, suppressed branches of Acacia mangium. The latter fungus has been reported to cause stem canker of eucalypts in India (Sharma et al. 1990). Collections on tropical acacias, however, have suggested that it is a saprophyte. The characteristic dome-shaped fruiting bodies and beautifully striated ascospores of this fungus (Fig. 73) make it worthy of mention.

\section{Pathology}

Trees planted in unsuitable environments, for example infertile soils and climates to which they are poorly adapted (drought-prone areas), are more susceptible to canker diseases (Crist and Schoeneweiss 1975). Trees in dense stands, especially if suppressed or subjected to insect attack (either defoliation or stem borers), are more susceptible to attack by canker fungi. Poor silvicultural operations resulting in stem wounds also predispose trees to infection. The fungi are likely to be present in all stands at a low level, and vigorous trees can be infected but show no symptoms in the absence of environmental stress (Smith et al. 1996).

The pathogens gain access to stem tissue through wounds, either naturally caused or resulting from pruning or lopping of branches. They kill cambial tissue and sapwood but do not cause decay. Open lesions exposed by death of bark and cambium, however, can act as avenues for infection by decay fungi. Only four fungal genera are listed above as causing cankers, but there are many other fungi which are opportunist pathogens of stressed trees.

Corticium salmonicolor (see page 69) is clearly a primary canker pathogen with the potential to cause significant disease in plantations. A Phomopsis sp. is a cause of foliar spots in India (see page 61) but Phomopsis spp. are also commonly associated with stem cankers and a species of this genus was isolated along with $L$. theobromae from a severely cankered stand of A. auriculiformis in Kalimantan, Indonesia (Figs 68-70).

\section{Impacts}

Impacts of these pathogens can be expected to be small in vigorous, well managed stands, and occurrence may be limited to suppressed trees. Where stands are stressed, for example if species or provenances are poorly adapted to climatic and edaphic factors, incidence of cankers can be significant. Very severe cankers were reported by Pongpanich (1997) on A. auriculiformis associated with infection by Botryosphaeria sp. in a trial in western Thailand, with up to $80 \%$ mortality in some seedlots (Figs 63-65). In a replicate planting at a more fertile site in Thailand with higher rainfall there was little or no mortality and only minor crown dieback. A trial at Riam Kiwa in South Kalimantan, Indonesia, containing many of the same provenances as those in Thailand, was severely affected by a canker disease (Figs 68-70). At Riam Kiwa there were major differences in impact on different provenances, those from the Northern Territory being significantly more affected than those from Papua New Guinea and north Queensland (Fig. 70). Lasiodiplodia theobromae (Fig. 71D) and Phomopsis sp. (Fig. 52) were isolated from cankers on these trees, but their role in the disease was not clearly established (Hadi and Nuhamara 1997). A plantation of 2 ha of a single seed 
source of A. aulacocarpa at Sakaerat in eastern Thailand suffered about $40 \%$ mortality through combined attack by borers and infection by Botryosphaeria sp. (Fig. 66).

In southern India, severe basal cankers of small plantings of A. crassicarpa in two locations were associated with infection by $L$. theobromae (Sharma and Florence 1997). In a planting of A. aulacocarpa at a different location, a Cytospora species was associated with damaging cankers. Also in India, $N$. mangiferae caused a serious die-back disease of A. mangium and A. auriculiformis in Kerala and Karnataka States (Sharma and Florence 1996).

\section{Control and management}

The only feasible control is through good matching of species and provenance to climatic and edaphic factors and avoidance of stress through good silviculture (spacing, thinning). Avoidance of wounds will reduce entry points for pathogens. Results from Kalimantan suggest that selection at the provenance level may avoid significant incidence of canker diseases. In South Kalimantan, Papua New Guinea provenances performed best, but this may not hold for other locations.

\section{References}

Browne, F.G. 1968. Pest and Diseases of Forest Plantation Trees. Clarendon Press, Oxford, $1330 \mathrm{p}$.

Crist, C.R. and Schoeneweiss, D.F. 1975. The influence of controlled stresses on susceptibility of European white birch stems to attack by Botryosphaeria dothidea. Phytopathology 65: 369-373.

Gibson, I.A.S. 1975. Diseases of Forest Trees Widely Planted as Exotics in the Tropics and Southern Hemisphere, Part I. Important members of the Myrtaceae, Leguminosae, Verbenaceae and Meliaceae. Commonwealth Mycological Institute, CAB, U.K., 51 p.

Hadi, S. and Nuhamara, S.T. 1997. Diseases of species and provenances of acacias in West and South Kalimantan, Indonesia. In: Old, K.M., Lee, S.S. and Sharma, J.K. eds. Diseases of Tropical Acacias. Proceedings of an international workshop held at Subanjeriji (South Sumatra), 28 April - 3 May, 1996. CIFOR Special Publication, $23-52$.

Lenné, J.M. 1992. Diseases of multipurpose woody legumes in the tropics; a review. Nitrogen Fixing Tree Research Reports 10: 13-29.

Old, K.M., Kobayashi, T. and Yuan, Z.Q. 1991. A Valsa teleomorph for Cytospora eucalypticola. Mycological Research 95: 1253-1256.

Pongpanich, K. 1997. Diseases of Acacia species in Thailand. In: Old, K.M., Lee, S.S. and Sharma, J.K. eds. Diseases of Tropical Acacias. Proceedings of an International Workshop held at Subanjeriji (South Sumatra), 28 April - 3 May, 1996. CIFOR Special Publication, 62-67. 
Punithalingam, E. and Waterston, J.M. 1970. C.M.I. Descriptions of Pathogenic Fungi and Bacteria No. 274. Commonwealth Mycological Institute, Kew, England, 2 p.

Roux, J. and Wingfield, M.J. 1997. Survey and virulence of fungi occurring on diseased Acacia mearnsii in South Africa. Forest Ecology and Management 99: 327-336.

Sharma, J.K., Mohanan, C. and Florence, E.J.M. 1990. Diseases of forest trees in Kerala. Evergreen (Trichur) 24: 8-10.

Sharma, J.K. and Florence, E.J.M. 1996. Fungal pathogens as a threat to tropical acacias - a case study of India. Kerala Forest Research Institute Research Report No. 113,44 p.

Sharma, J.K and Florence, E.J.M. 1997. Fungal pathogens as a potential threat to tropical acacias; case study of India. In: Old, K.M., Lee, S.S. and Sharma, J.K. eds. Diseases of Tropical Acacias. Proceedings of an International Workshop held at Subanjeriji (South Sumatra), 28 April - 3 May, 1996. CIFOR Special Publication, 70-107.

Sivanesan, A. 1975. Redisposition and descriptions of some Amphisphaeria species and a note on Macrovalsaria. Transactions of the British Mycological Society 65: 395-402.

Smith, H., Wingfield, M.J., Crous, P.W. and Coutinho, T.A. 1996. Sphaeropsis sapinea and Botryosphaeria dothidea endophytic in Pinus spp. and Eucalyptus spp. in South Africa. South African Journal of Botany 62: 86-88. 


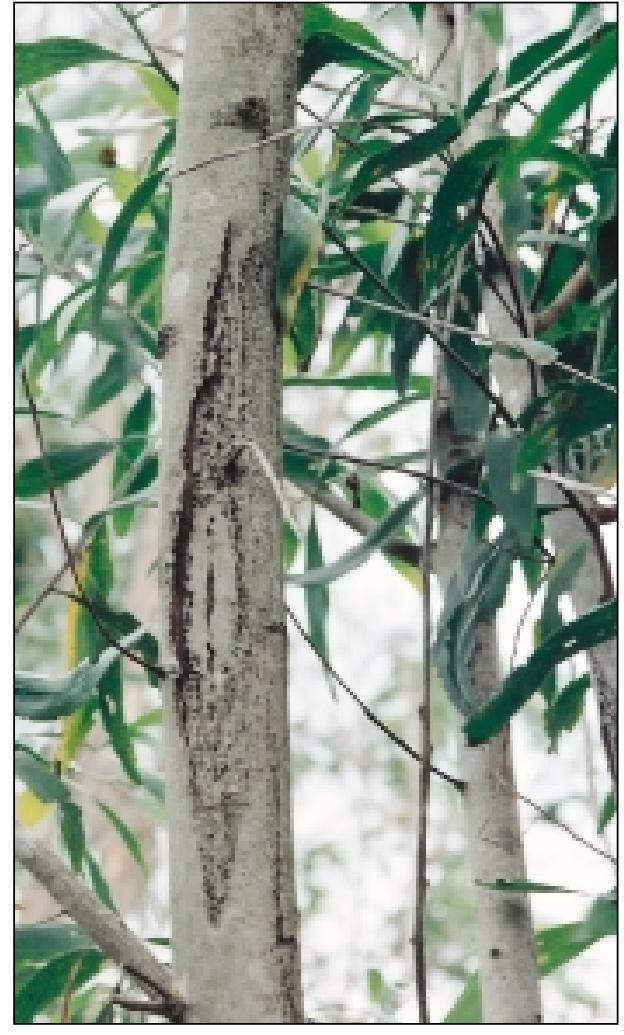

Fig. 63

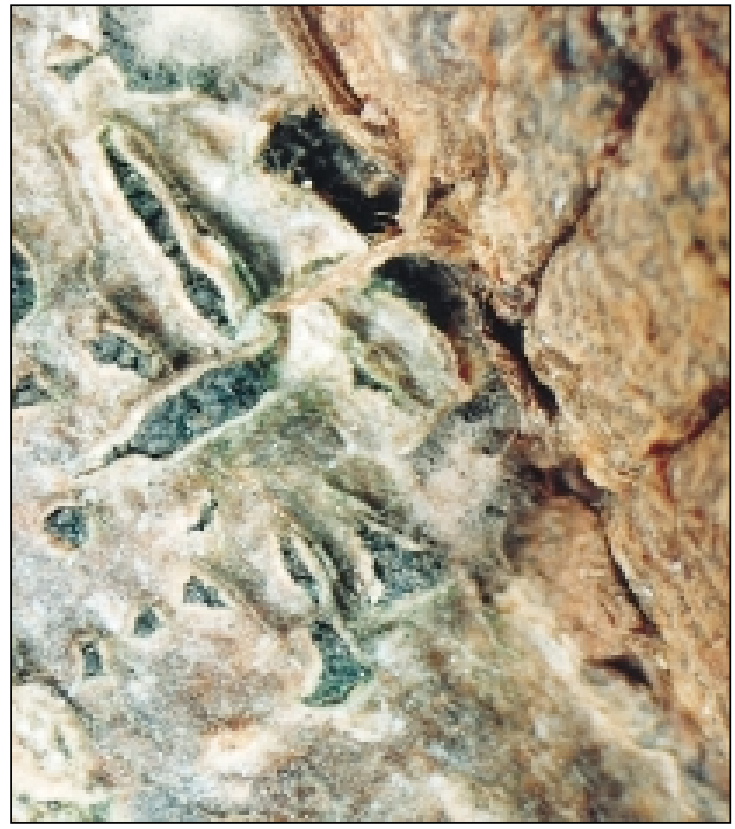

Fig. 65

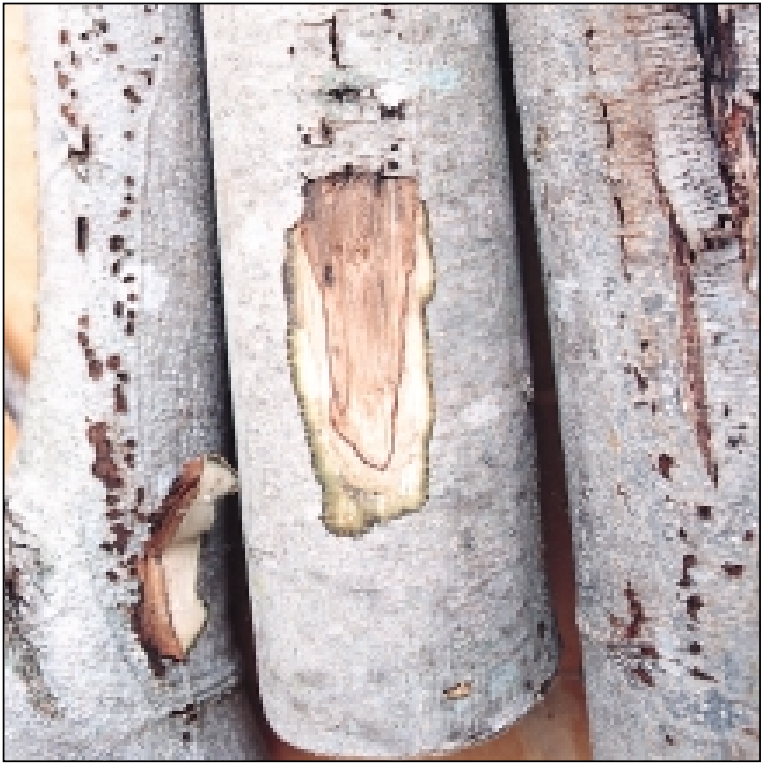

Fig. 64

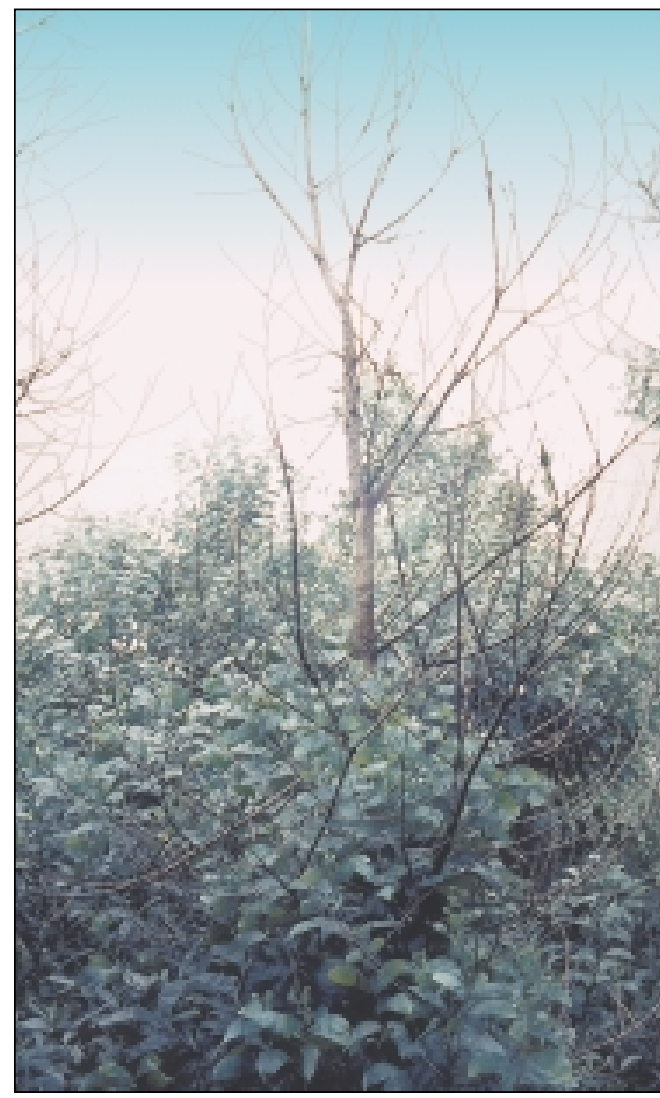

Fig. 66

Fig. 63 Canker on Acacia auriculiformis caused by Botryosphaeria sp. (Thailand)

Fig. 64 Cankers from tree in Fig. 63 showing sapwood discoloration and cambial death

Fig. 65 Detail of fruiting bodies of Botryosphaeria sp.

Fig. 66 Main shoot death due to Botryosphaeria infection, A. aulacocarpa (Thailand) 


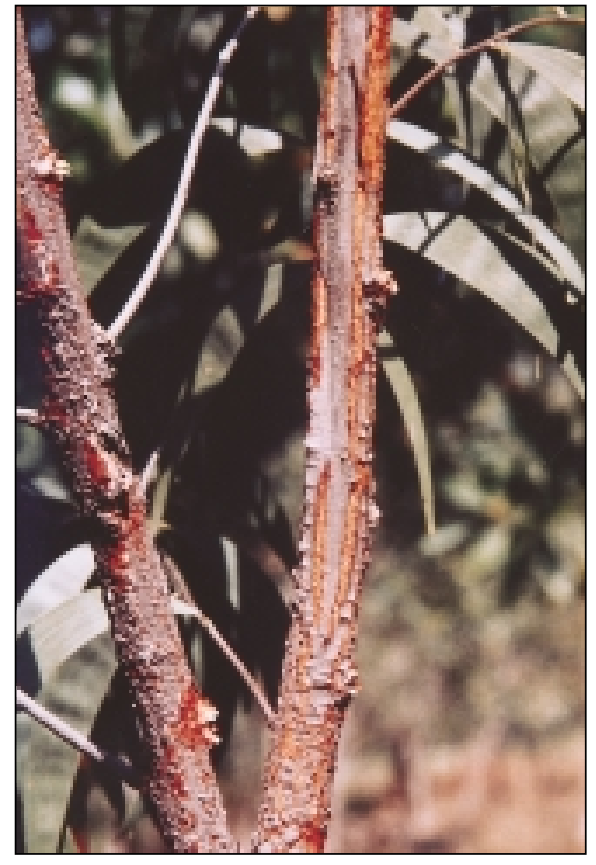

Fig. 67

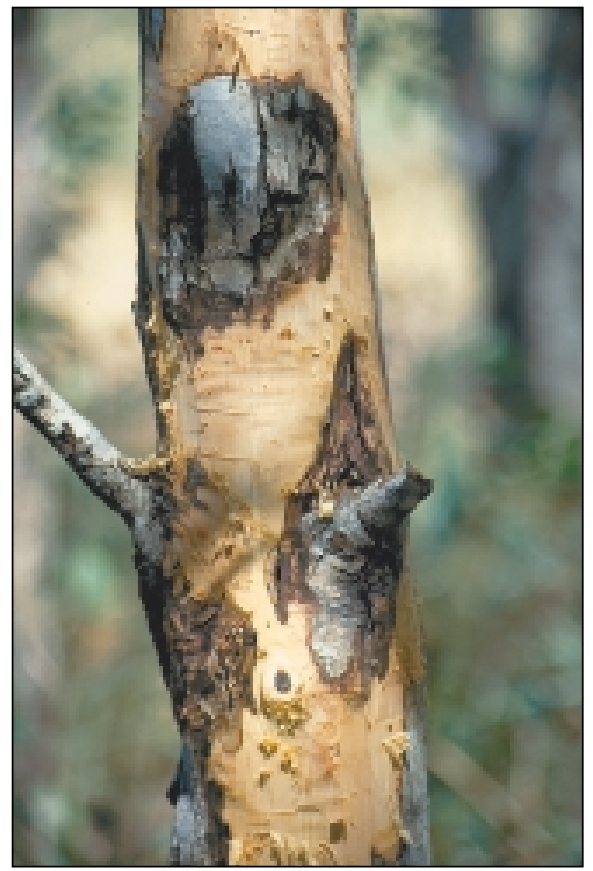

Fig. 69

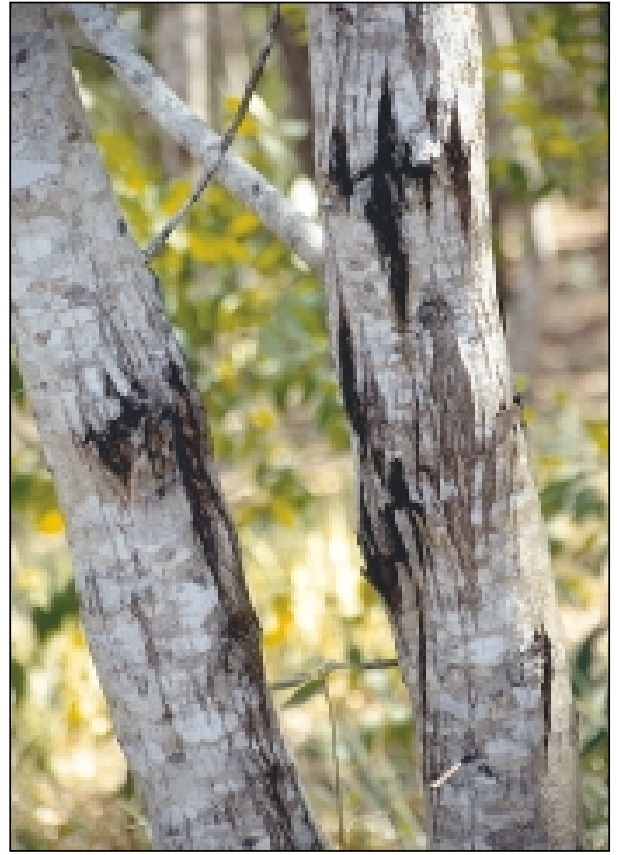

Fig. 68

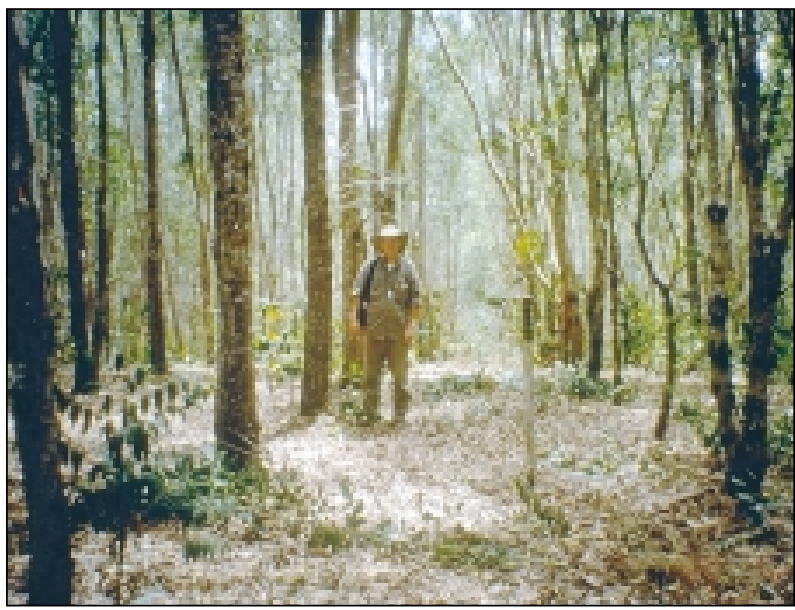

Fig. 70

Fig. 67 Cankered shoot of Acacia auriculiformis associated with infection by Cytospora sp. (India) Fig. 68 Cankered shoot of A. auriculiformis associated with Phomopsis sp. and Lasiodiplodia sp. (South Kalimantan)

Fig. 69 Tree from stand shown in Figs 68 and 70 with bark removed to show association of cankers with branch stubs

Fig. 70 A. auriculiformis provenance trial (South Kalimantan). The Papua New Guinea provenance (left) had few cankers, whereas the northern Australia provenance (right) was badly cankered 


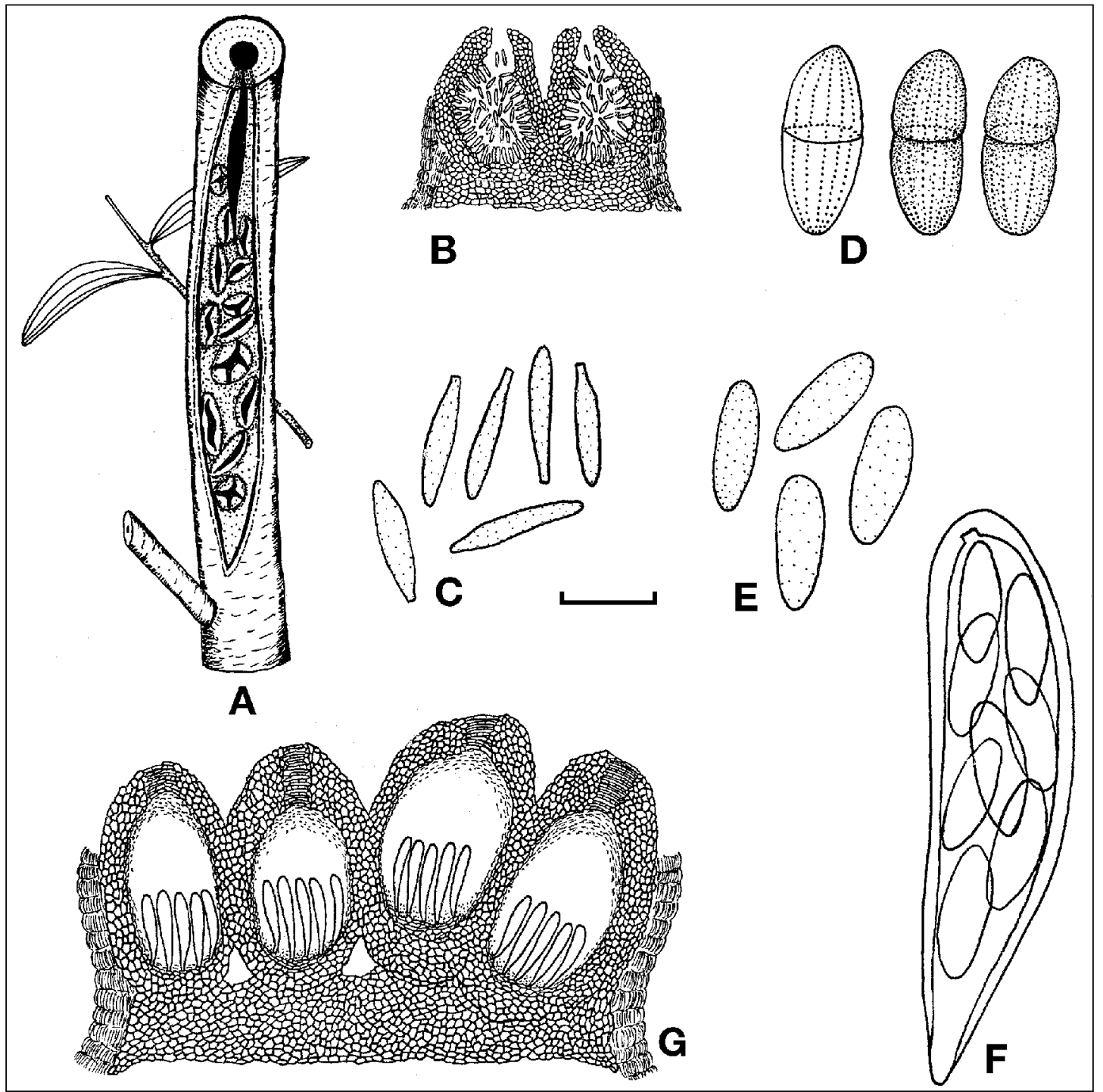

Fig. 71

Fig. 71 Botryosphaeria spp.

A. Canker on Acacia auriculiformis associated with Botryosphaeria sp. infection

B. Longitudinal section of fruiting structure of Dothiorella sp.

C. Conidia of Dothiorella

D. Conidia of Lasiodiplodia theobromae

E. Ascospores of Botryosphaeria sp.

F. Ascus of Botryosphaeria sp. with eight ascospores

G. Longitudinal section of fruiting structure of Botryosphaeria sp.

$(\mathrm{Bar}=100 \mu \mathrm{m}$ for $\mathrm{B}$ and $\mathrm{G} ;=15 \mu \mathrm{m}$ for $\mathrm{C}, \mathrm{E}$ and $\mathrm{F} ;=12.5 \mu \mathrm{m}$ for $\mathrm{D}$; not to scale for $\mathrm{A})$ 


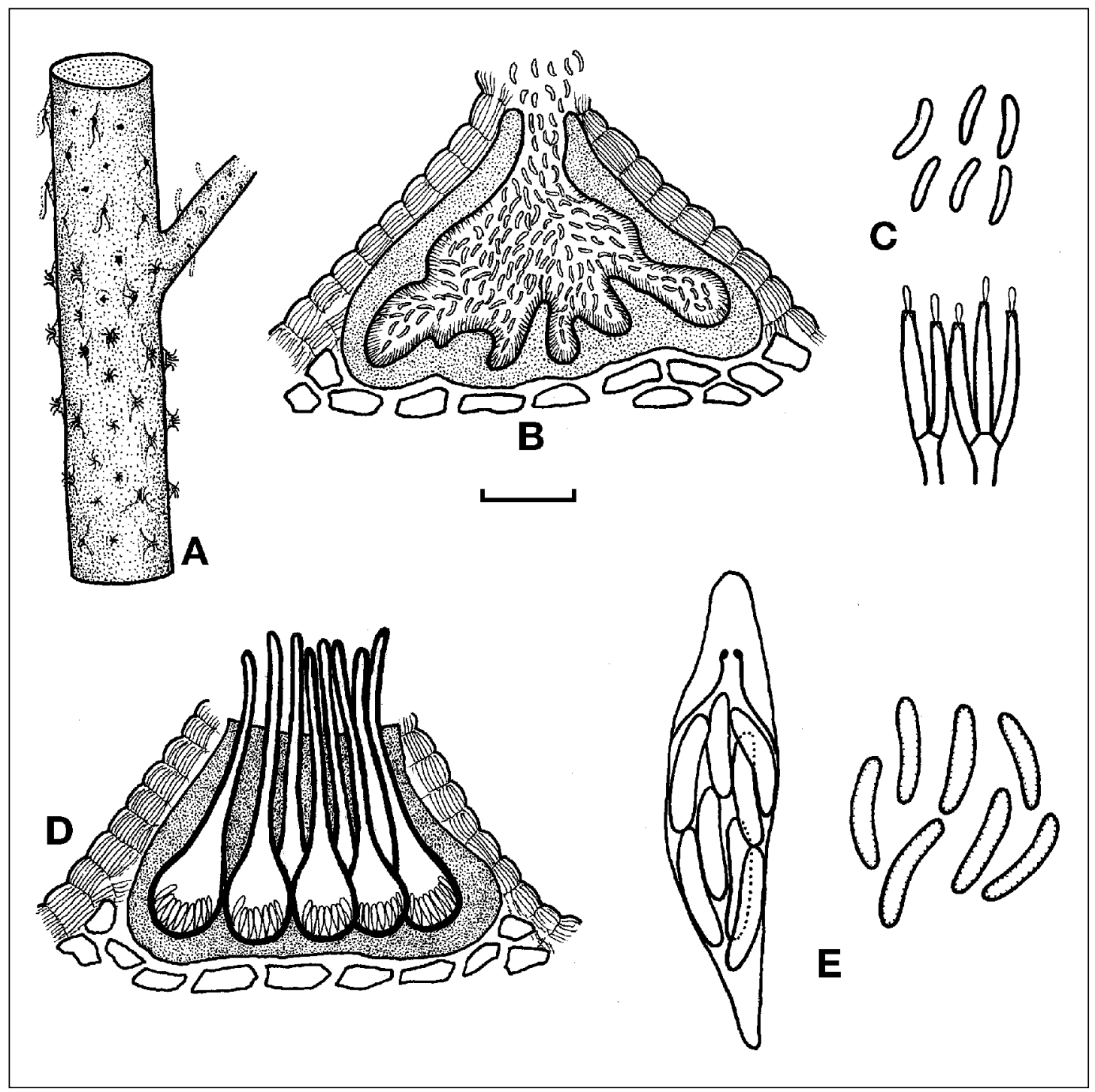

Fig. 72

Fig. 72 Cytospora and Valsa spp.

A. Portion of stem showing conidial tendrils of Cytospora sp. (above) and converging necks of perithecia of Valsa sp. through the bark (below)

B. Longitudinal section through fruiting structure of Cytospora sp.

C. Conidia and conidiophores of Cytospora sp.

D. Longitudinal section through fruiting structures of Valsa sp.

E. Ascus and ascospores

$(\mathrm{Bar}=120 \mu \mathrm{m}$ for $\mathrm{B}$ and $\mathrm{D} ;=10 \mu \mathrm{m}$ for $\mathrm{C} ;=7 \mu \mathrm{m}$ for $\mathrm{E}$; not to scale for $\mathrm{A}$ ) 


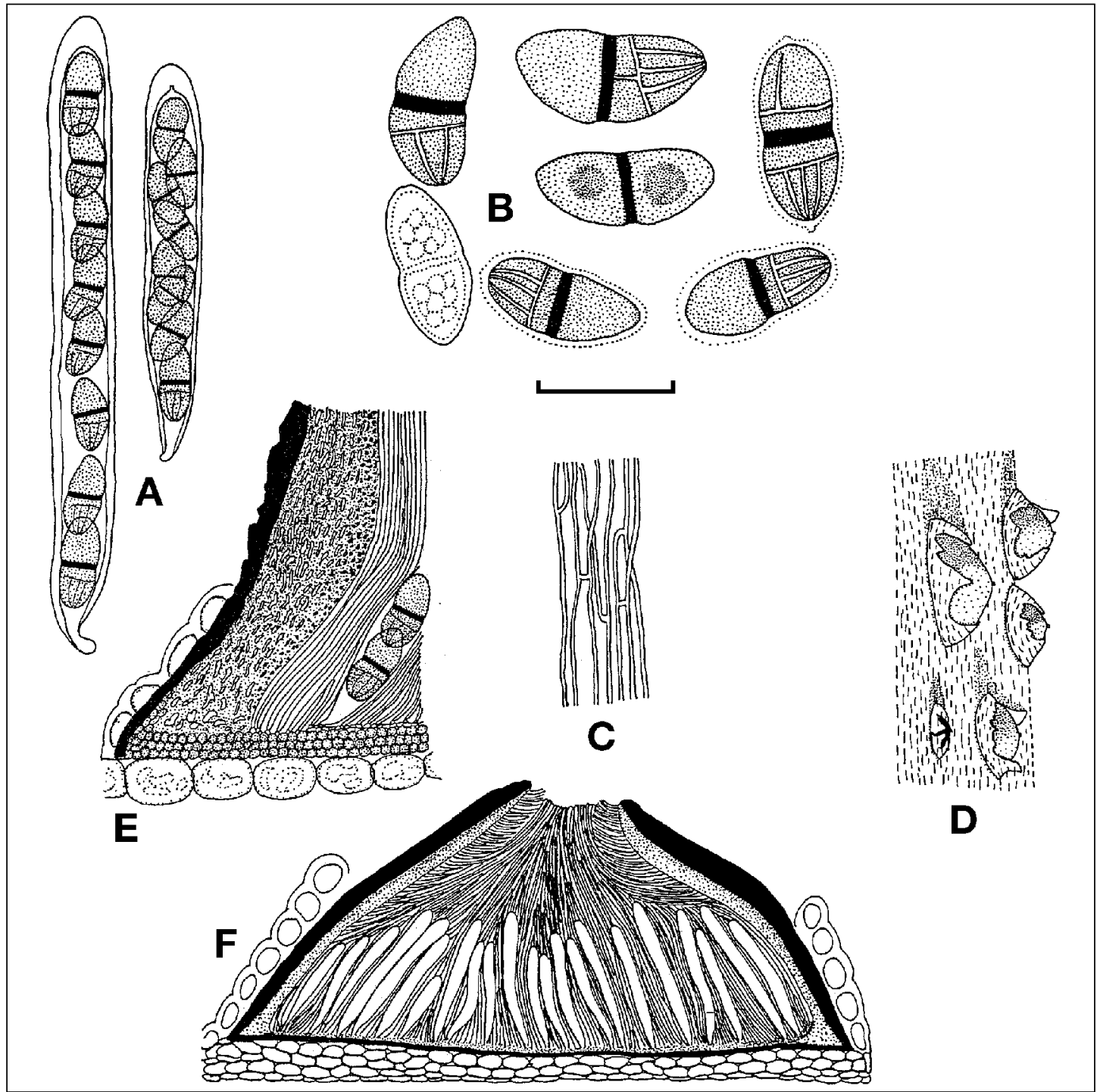

Fig. 73

Fig. 73 Macrovalsaria megalospora on Acacia mangium
A. Asci
B. Ascospores
C. Sterile hyphae
D. Group of conical fruiting bodies bursting through the bark
E. Detail of fruiting body wall
F. Longitudinal section of fruiting structure
$(\mathrm{Bar}=30 \mu \mathrm{m}$ for $\mathrm{B} ;=60 \mu \mathrm{m}$ for $\mathrm{A}, \mathrm{C}$ and $\mathrm{E} ;=240 \mu \mathrm{m}$ for $\mathrm{F} ;=1 \mathrm{~mm}$ for $\mathrm{D})$ 


\section{HEART ROT}

\section{Disease}

Heart rot, reput teras (Bahasa Malaysia), busuk hati, busuk umbut (Bahasa Indonesia)

\section{Causal organisms}

A range of hymenomycetes are known to be associated with heart rot of acacias, but the fungi associated with Acacia mangium have only recently been identified. Phellinus pachyphloeus and Trametes palustris were reported from India (Mehrotra et al. 1996) while P. noxius, Tinctoporellus epimiltinus and Rigidoporus hypobrunneus were found to be associated with heart rot of A. mangium in Peninsular Malaysia and East Kalimantan (Lee and Noraini Sikin 1999). P. noxius was associated with heart rot of A. crassicarpa in Vanuatu. Oxyporus cf. latemarginatus was also associated with heart rot of A. mangium in Peninsular Malaysia (Lee and Noraini Sikin 1999).

\section{Host range}

Heart rot is generally a defect of old trees and is known to occur in a wide range of tree species. It has also been reported to occur in many species of acacias, including A. auriculiformis and A. mangium, but its widespread occurrence in relatively young trees of the latter species was unexpected. Heart rot has not been reported from A. aulacocarpa or A. crassicarpa. However, this may be because these two species have not been systematically surveyed for incidence of decay.

\section{Known distribution}

Heart rot fungi are generally pan-tropical or cosmopolitan saprophytic wood decay fungi or wound parasites. Some species such as $P$. noxius (Fig. 76) and $R$. hypobrunneus are also facultative parasites that can cause root and butt rot diseases.

\section{Symptoms}

Trees with heart rot usually appear healthy as there are seldom any visible symptoms. However, the presence of dead or broken branches, wounds, scars, cracks and forks can be indicators of the presence of decay. Fruiting bodies proliferating on living or recently dead trees are indicative of the presence of decay and assist in the identification of causal agents of heart rot and root rot (Figs 78-82).

The type of rot most commonly found in A. mangium heartwood is a white fibrous rot (Figs 74-75) (Gibson 1981) but the colour and texture of the rotted wood varies depending on the fungus involved (Lee and Noraini Sikin 1999). The rot may occur as small pockets or throughout the length of the heartwood (Fig. 75) but is evident only when the tree is felled. The point of invasion can usually be traced to a wound or decayed branch stub. 


\section{Pathology}

Wounds are usually the entry points for the wood decay fungi. On A. mangium trees wounds include broken branches, mechanical injuries and branch stubs left after self-pruning or through singling and artificial pruning operations. Studies by Schmitt et al. (1995) showed that the wound response in A. mangium was slow and that fungal hyphae rapidly invaded the wound-affected xylem, resulting in defect development three to four weeks after wounding. They also found that accumulations of chemicals (extractives) in the lumina of heartwood vessels were hardly toxic to the decay fungi that could be quite aggressive.

The incidence and extent of the decay is highly variable and depends on many factors including species, location of wound on the stem, size and season of injury, age of wounds, stand dynamics and decay organism(s). Fungi that cause wood discoloration such as Ceratocystis fimbriata, Chalara sp. and Phialophora sp. have been isolated from wounds on A. mangium (Lee 1986; Lee et al. 1988). Such fungi are probably involved in the early colonization of the damaged wood before subsequent invasion by the wood decay fungi. The actual mode of infection of the heartwood in A. mangium has not yet been investigated in detail. It has been hypothesized that in some areas of South-East Asia, without a prolonged dry season the self-pruning ability of A. mangium is reduced, thereby favouring the development of entry points for the decay fungi causing heart rot (Lee and Arentz 1997).

\section{Impact}

In Peninsular Malaysia, a volume loss of between $0.7 \%$ and $17.5 \%$ of the merchantable timber of A. mangium has been reported as a result of heart rot (Lee et al. 1988; Zakaria et al. 1994). Up to $85 \%$ of trees sampled have shown some incidence of decay. In a study carried out in Sabah, Malaysia, the volume of timber affected by decay ranged from $0.02 \%$ to $18.1 \%$ but mean volume loss was approximately $1 \%$ loss of merchantable volume (Mahmud et al. 1993). Although the disease is also known to be present in A. mangium plantations in Bangladesh, India, Indonesia and Thailand, no detailed data are available.

The small volume of wood affected by heart rot is believed to have little impact on utilization of A. mangium wood for pulp and paper manufacture and medium density fiberboard (MDF). However, heart rotted timber would not be suitable for general utilization purposes such as construction, due to loss in structural strength and poor recovery of high-value products during processing.

\section{Control and management}

There is a need for species-site matching studies to establish the heart rot susceptibility of A. mangium when planted in locations with year-round humid climates. Similar studies are needed for the other tropical acacia plantation species.

As the heart rot fungi are wound parasites which enter the trees through injured surfaces and branch stubs, lopping off branches with parangs or machetes should be avoided. Singling of multi-stemmed, fast growing trees (Fig. 77) creates large stem wounds that heal slowly and are prone to invasion by fungi. Tree improvement aimed at producing single-stemmed trees with small-diameter lower branches which self-prune effectively should in future reduce the extent of heart rot. 
Sharp pruning shears or saws should be used for pruning and singling operations, and care should be taken to cut branches close to the main bole while avoiding injury to the branch collar. Pruning and singling operations should be carried out according to schedule so that only young and small-diameter branches are pruned. Tree vigour should be maintained to promote rapid healing of the small branch stubs, which can function as infection courts.

Wound protectants are commercially available but their effectiveness on A. mangium has not been tested. Many formulations have been shown to be ineffective in halting microbial activity and although some are effective fungicides, they may prove phytotoxic to the tree (Mercer 1982). Wound protectants are also costly and impractical for large-scale use in forest plantations.

\section{References}

Gibson, I.A.S. 1981. Seed source establishment and tree improvement - Sabah, Malaysia. FAO/UNDP-MAL/78/009, Rome. Forest Mycology Consultant's Report No. 3, 45 p.

Ivory, M.H. and Daruhi,G. 1993 New host records for Phellinus noxius in Vanuatu. FAO Plant Protection Bulletin 41: 37-38.

Lee, S.S. 1986. Discoloration of the heart wood of Acacia mangium - a preliminary report. In: Proceedings of the Second International Conference on Plant Protection in the Tropics, 331-332.

Lee, S.S. and Arentz, F. 1997. A possible link between rainfall and heart rot incidence in Acacia mangium? Journal of Tropical Forest Science 9: 441-448.

Lee, S.S. and Noraini Sikin, Y. 1999. Fungi associated with heart rot of Acacia mangium trees in Peninsular Malaysia and East Kalimantan. Journal of Tropical Forest Science 11: 240-254.

Lee, S.S., Teng, S.Y., Lim, M.T. and Razali, A.K. 1988. Discoloration and heart rot of Acacia mangium Willd.: some preliminary results. Journal of Tropical Forest Science 1: 170-177.

Mahmud, S., Lee, S.S. and Ahmad, H. 1993. A survey of heart rot in some plantations of Acacia mangium Willd. in Sabah. Journal of Tropical Forest Science 6: 37-47.

Mehrotra, M.D., Pandey, P.C., Chakrabarti, K., Sharma, S. and Hazra, K. 1996. Root and heart rots in Acacia mangium plantations in India. Indian Forester 122: 155-160.

Mercer, P.C. 1982. Basidiomycete decay in standing trees. In: Frankland, J.C., Hedger, J.N. and Swift, M.J. eds. Decomposer Basidiomycetes - Their Biology and Ecology. British Mycological Society Symposium 4, 143-160. Cambridge University Press, Cambridge.

Schmitt, U., Liese, W., Hong, L.T. and Killmann, W. 1995. The mechanisms of wound response in Acacia mangium. IAWA Journal 16: 425-432.

Zakaria, I., Wan Razali, W.M., Hashim, M.N. and Lee, S.S. 1994. The incidence of heartrot in Acacia mangium plantations in Peninsular Malaysia. FRIM Research Pamphlet No. $114,15 \mathrm{p}$. 


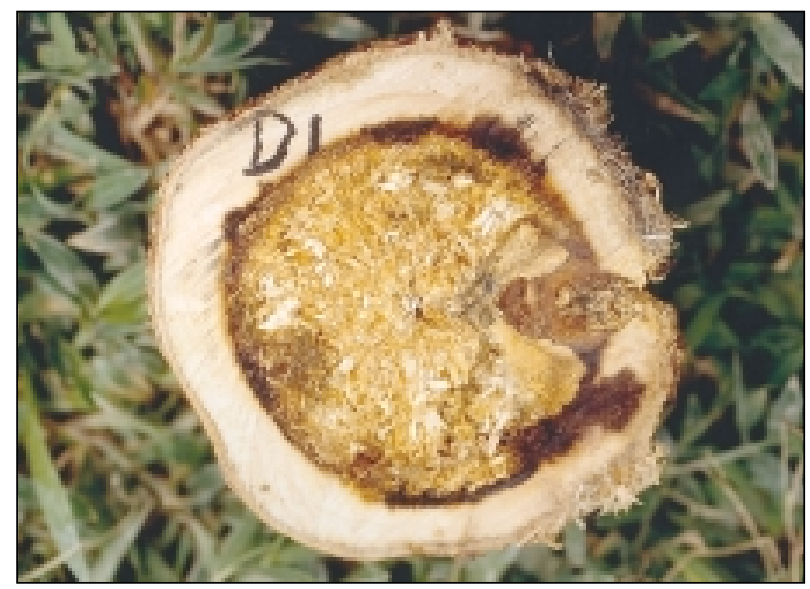

Fig. 74
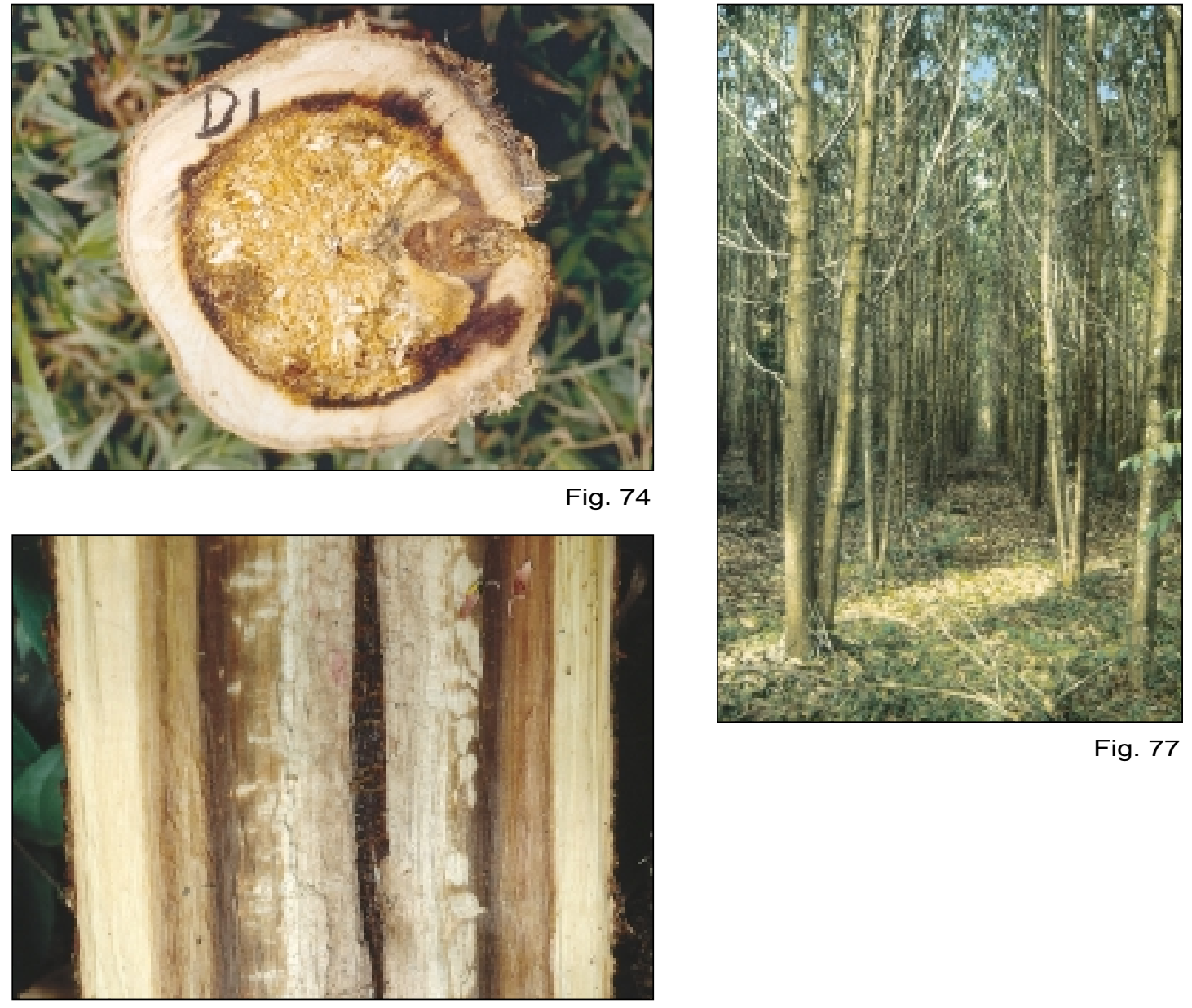

Fig. 77

Fig.75

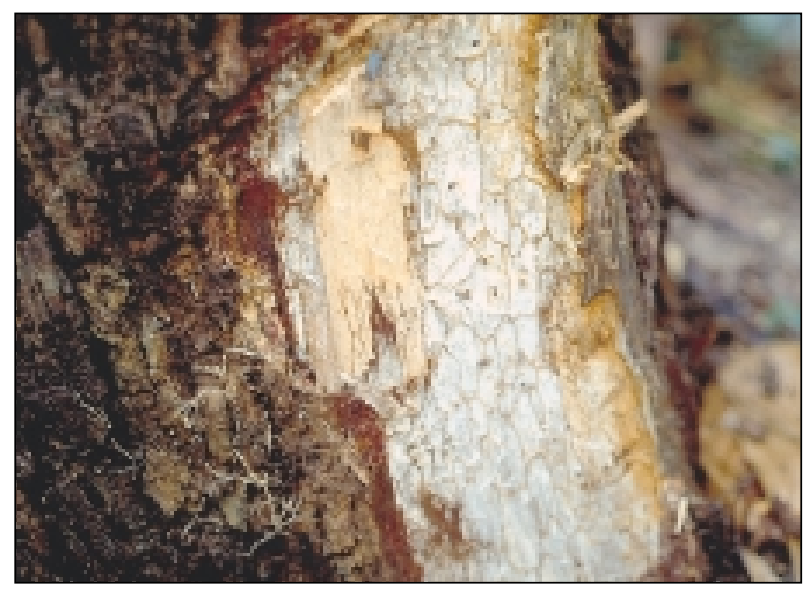

Fig. 76

Fig. 74 Heart rot of Acacia mangium (Peninsular Malaysia)

Fig. 75 White fibrous rot of $A$. mangium associated with Phellinus noxius (Peninsular Malaysia)

Fig. 76 Characteristic mycelial growth on Phellinus noxius under the bark of A. mangium

Fig. 77 Fast growing multistemmed A. mangium. Singling and pruning creates wounds for infection by heart rot fungi (Sumatra) 


\section{ROOT ROT}

\section{Disease}

Root rot, reput akar (Bahasa Malaysia), busuk akar (Bahasa Indonesia)

\section{Causal organisms}

The fungi associated with root rot diseases found in tropical Acacia plantations are mainly members of the basidiomycetes, e.g. Ganoderma spp., Phellinus noxius and Rigidoporus lignosus. Root pathogens of other acacia species are discussed in Gibson (1975). In the nursery a different group of fungi, mainly members of the mitosporic fungi, are associated with root rot diseases such as damping-off and dieback of seedlings. Recently, G. philippii, P. noxius, Tinctoporellus epimiltinus and Amauroderma cf. parasiticum were also found to be associated with root rot of $A$. mangium trees in Peninsular Malaysia (Lee in press). Unknown basidiomycetes were reported to be associated with root rot in A. aulacocarpa and A. crassicarpa in India (Sharma and Florence 1997).

\section{Host range}

The fungi causing root rot affect a wide range of tree species, including forest trees, fruit trees and amenity trees. Many species of acacias, including A. aulacocarpa, A. auriculiformis, $A$. crassicarpa and $A$. mangium have been reported to be attacked by root rot fungi which colonize the roots of the trees and decay the wood and bark.

\section{Known distribution}

The basidiomycete fungi causing root rot of acacias are widely distributed. Many tropical species of Ganoderma (Figs 79-82) are well known wood decay fungi while species of Phellinus (Figs 76, 78) decay heartwood, cause root rots and cankers of live standing trees, and destroy slash and other wood residues (Ivory 1996). Collectively, species of Phellinus (Fig. 78) are probably responsible for more timber loss than any other genus of wood destroying fungi in the world (Larsen and Cobb-Poulle 1981).

\section{Symptoms}

In the plantation, root rot disease centres are characterised by slowly enlarging patches of dead and dying trees (Figs 83-85). The foliage of affected trees is usually paler green, much reduced in size and sparse due to reduced water and mineral uptake. There is a general decline in the crown condition and the growth rate is poor. Young shoots may wilt and some of the stressed trees may produce fruits/seeds out of season. Trees in advanced states of root rot are also very susceptible to wind throw.

The main types of root diseases affecting acacias can be distinguished by the colour of the infected roots; the recognised types being red root disease, brown root disease and the less common black root and white root diseases. In red root disease, the roots are characteristically covered by a wrinkled reddish brown rhizomorphic skin that is very evident when the root is 
washed clean of adhering soil (Figs 86-87). A white mottling pattern is evident on the underside of the infected bark (Fig. 87) and there is a very characteristic odour. In the early stages of infection, the wood is hard and no colour change is discernible, but in advanced stages, the wood becomes pale buff and spongy or dry depending on the soil condition. This is the most common type of root disease observed in A. auriculiformis, A. crassicarpa and A. mangium plantations and is associated with a Ganoderma sp., most likely G. philippii.

In brown root disease the roots are encrusted in a mass of earth and sand intermingled with rusty-brown velvety patches. Advanced stages of the disease are easily recognised by the brown honeycomb-like, zig-zag pattern of lines formed by plates of hyphae in the wood (Fig. 76). These symptoms are characteristic of infection by $P$. noxius and this diagnosis has been confirmed by the production of sporocarps experimentally and by pathogenicity tests (Lee and Noraini Sikin 1998).

In black root disease, which is most probably associated with $A$. cf. parasiticum (Lee in press), the infected root is covered by a thin black crust which can be easily mistaken for necrotic tissue. In white root disease, thick white, stringy rhizomorphs adhere to the surface of the root. This disease is most probably associated with a species of Rigidoporus.

\section{Pathology}

These basidiomycete fungi usually exist as endemic saprophytes in the natural forest causing little if any problem. When land is cleared for plantation establishment, these fungi can survive on root remains, tree stumps and other woody debris in the soil. The fungi depend on large food bases for their pathogenic activities and once established on dead wood, they can become active and virulent parasites, infecting living trees through their roots. The ability of these root pathogens to penetrate and colonize the root system is usually closely related to the general health of the tree. Generally trees suffering from stress or disturbances and/or of poor vigour are more susceptible to root disease, but there are exceptions where some fungi are able to attack vigorously growing trees.

Fungi like Ganoderma spp. usually invade roots of trees with reduced vigour (Fig. 88), while others like $R$. lignosus spread through the soil by means of rhizomorphs. Still others like $P$. noxius depend on contact between roots of a healthy potential host with the substrate on which the fungus is growing (Nandris et al. 1987).

\section{Impact}

Root rot is a significant disease of tropical acacia plantations in Australia, Indonesia, Malaysia, Thailand and India. In a long-term disease survey of A. mangium plantations of various ages in Peninsular Malaysia, Lee (in press) found that in severely infected areas, root rot caused more than $40 \%$ mortality of trees aged between 9 and 14 years old. In the Gogol Valley of Papua New Guinea, Arentz (1986) reported 29\% mortality of 5-year-old A. mangium trees due to root disease. The disease is particularly severe in second-rotation A. mangium and A. crassicarpa plantations in Sumatra, Indonesia, where trees as young as 6 months old have been killed by red root disease (Figs 84-87). This high incidence of disease may be explained by the presence of root rot in first-rotation plantings coupled with the large amount of woody debris left behind after harvest. Saprophytic survival of these fungi in harvesting debris may provide inoculum for the second-rotation crop. 


\section{Control and management}

Control of root rot diseases is difficult as the pathogens survive on woody material in the soil. In rubber plantations, root diseases are managed by cultural practices, especially thorough site clearing and establishment of creeping legume covers. During planting site preparation, woody debris should be removed and destroyed to reduce sources of inoculum. Legume covers can be used to exhaust the food reserves of potentially dangerous inocula by encouraging futile growth of the fungus and by dissipating the infective potential of large sources of inoculum.

In plantations of rubber and of $A$. catechu, isolation trenches have been effectively used to check the spread of the disease (Anon. 1974; Bakshi 1974). However, such trenches are expensive and difficult to construct and may not be practical in industrial forest plantations where the trees are much more closely spaced.

Soil drenching with fungicides such as triademefon, propiconazole, hexaconazole, cyproconazole and penconazole has shown promise in the control of white root disease caused by $R$. lignosus. However, while effective control was obtained in cases of light infection, it was less effective against moderate infection levels (Ismail and Shamsuri 1998). Such treatments have not been tested in tropical acacia plantations and it is doubtful whether they will be used because of the high cost involved. Some promising results have been obtained in the use of biological control of root rot pathogens in the tropics (Bolland et al. 1989; Idwan et al. 1992; Yonnes 1998) but their practicability and sustainability on an operational scale have yet to be demonstrated.

In some logged lowland rainforest areas where mortality due to root rot is high, planting of resistant acacia cultivars or alternative species may have to be considered. This may be necessitated by the susceptibility of Acacia spp. to root rot and the fact that little can be done to control the disease. It has been suggested that the susceptible preferred species should be planted only in the second rotation after a first rotation of a resistant species. This would allow time for the stumps and roots of the original rainforest species to completely decay and disintegrate, thereby reducing inoculum levels of root pathogens.

\section{References}

Anonymous. 1974. Root diseases. Part II: Control. Planters' Bulletin 134: 157-164.

Arentz, F. 1986. Forest Pathology Lecture Notes. Papua New Guinea Forestry College, Bulolo.

Bakshi, B.K. 1974. Control of root diseases in plantations in reforested stands (with special reference to khair, sissoo, Eucalyptus, etc.). Indian Forester 100: 77-78.

Bolland, L., Tierney, J.W., Winnington-Martin, S.M. and Ramsden, M. 1989. Investigations into the feasibility of biological control of Phellinus noxius and Poria vincta in Queensland hoop pine plantations. In: Morrison, D.J. ed. Proceedings of the Seventh International Conference on Root and Butt Rots. IUFRO Working Party S2.06.01. 9-16 August 1988. Pacific Forestry Centre, Victoria, British Columbia, Canada, 72-82. 
Gibson, I.A.S. 1975. Diseases of Forest Trees Widely Planted as Exotics in the Tropics and Southern Hemisphere. Part I. Important Members of the Myrtaceae, Leguminosae, Verbenaceae and Meliaceae. Commonwealth Mycological Institute, CAB, U.K., 51 p.

Idwan, S.L., Iraqi, H.A.I., Le Febvre, G., Kiffer, E. and Botton, B. 1992. Screening of some basidiomycetes for biological control of Rigidoporus lignosus, a parasite of rubber tree, Hevea brasiliensis. Mycological Research 96: 621-625.

Ismail, H. and Shamsuri, M.H. 1998. Current status of root diseases of rubber. Paper presented at the CABI Workshop on Ganoderma Diseases, 5-8 October 1998. MARDI Training Centre, Serdang.

Ivory, M.H. 1996. Diseases of forest trees caused by the pathogen Phellinus noxius. In: Forest Trees and Palms, Diseases and Control, 111-133 Oxford and IBH Publishing Co Pty Ltd. New Delhi/Calcutta, 334 p.

Larsen, M.J. and Cobb-Poulle, L.A. 1991. Phellinus (Hymenochaetaceae). A Survey of World Taxa. Synopsis Fungorum 3. Fungiflora: Oslo, Norway, 206 p.

Lee, S.S. 1999. The current status of root diseases of Acacia mangium Willd. In: Flood, J. Bridge, P. and Holderness, M. eds. Ganoderma Diseases of Perennial Crops. CABI. (in press)

Lee, S.S. and Noraini Sikin, Y. 1998. A technique for basidiocarp production of fungi isolated from decayed Acacia mangium Willd. In: Proceedings of the International Conference on Asian Network on Microbial Researches, 23-25 February 1998. Yogyakarta, Indonesia, 619-624.

Nandris, D., Nicole, M. and Geiger, J.P. 1987. Root rot diseases of rubber trees. Plant Disease 71: 298-306.

Sharma, J.K. and Florence, E.J.M. 1997. Fungal pathogens as a potential threat to tropical acacias: case study of India. In: Old, K.M., Lee, S.S. and Sharma, J.K. eds. Diseases of Tropical Acacias. Proceedings of an international workshop, Subanjeriji (South Sumatra), 28 April - 3 May 1996. CIFOR Special Publication, 70-107.

Yonnes, H. 1998. Potential control of Ganoderma in oil palm through prophylactic treatments. Paper presented at the CABI Workshop on Ganoderma Diseases, 5-8 October 1998. MARDI Training Centre, Serdang. 


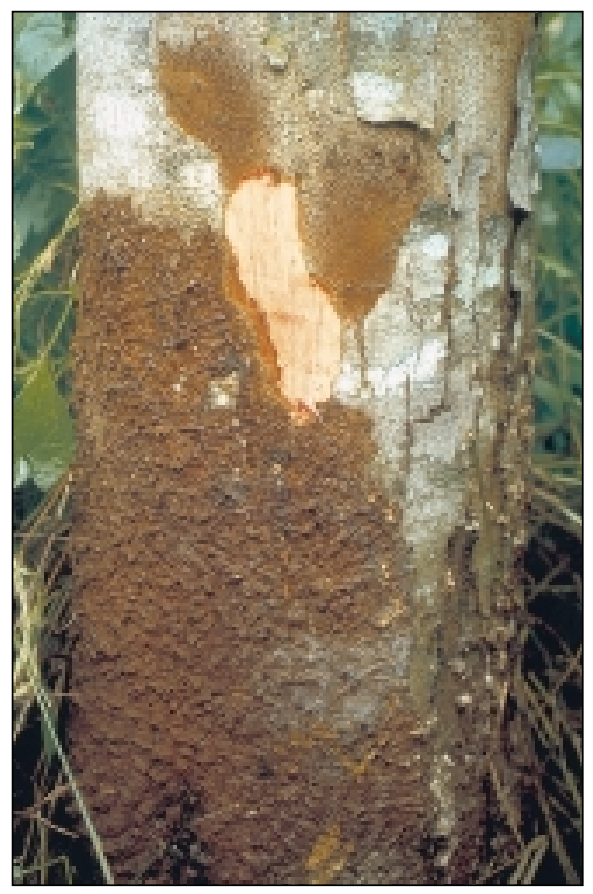

Fig. 78

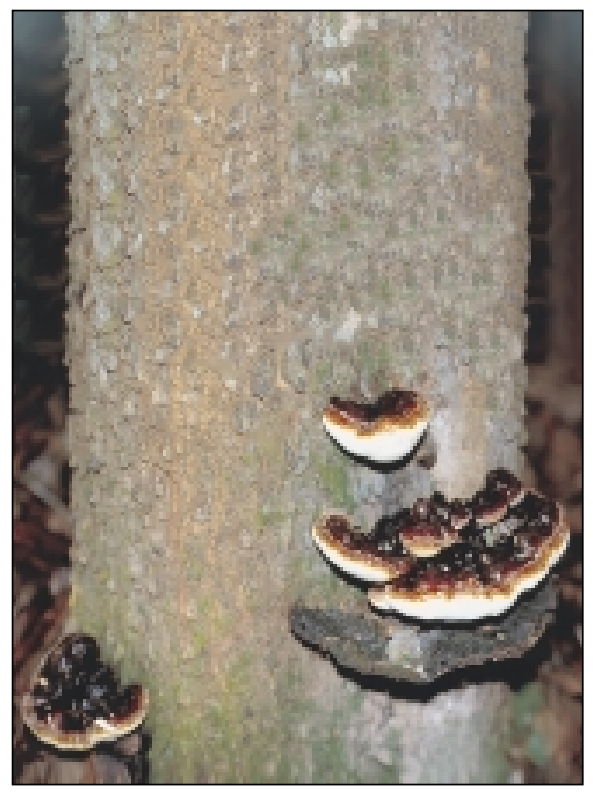

Fig. 79

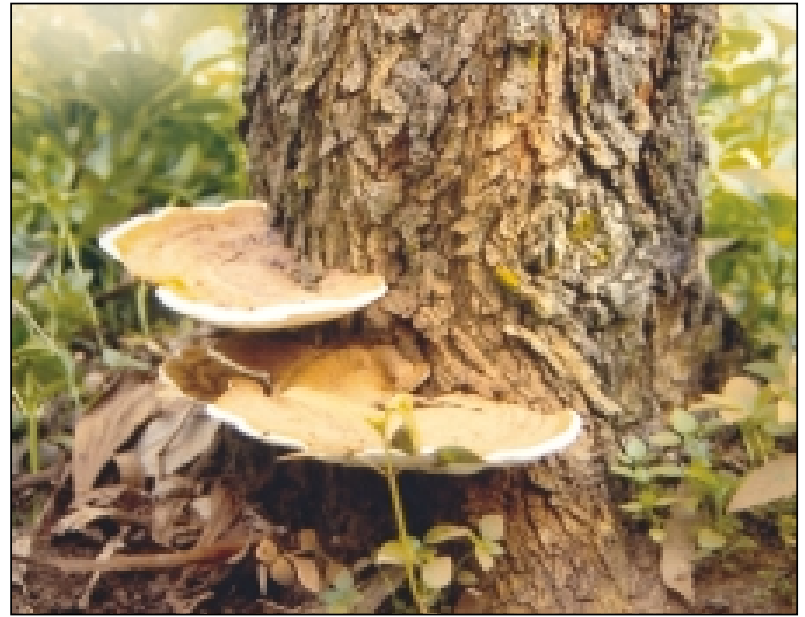

Fig. 80

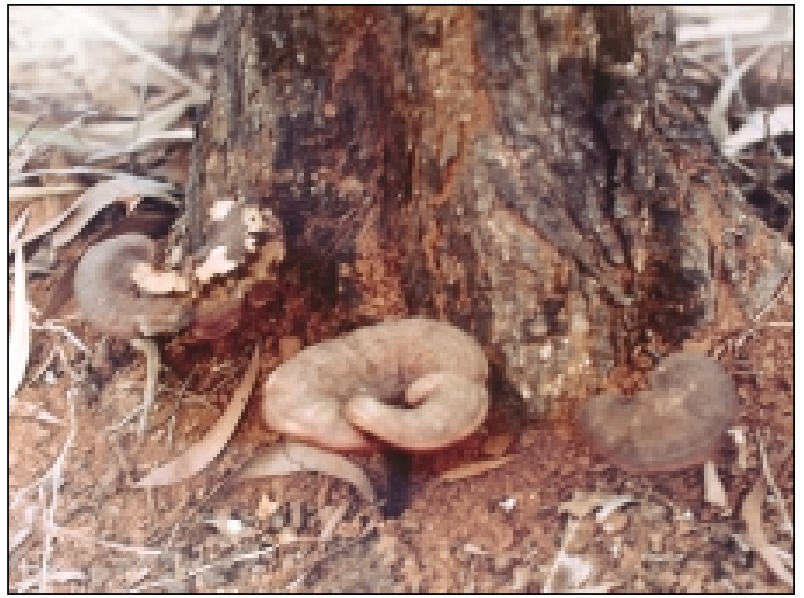

Fig. 81

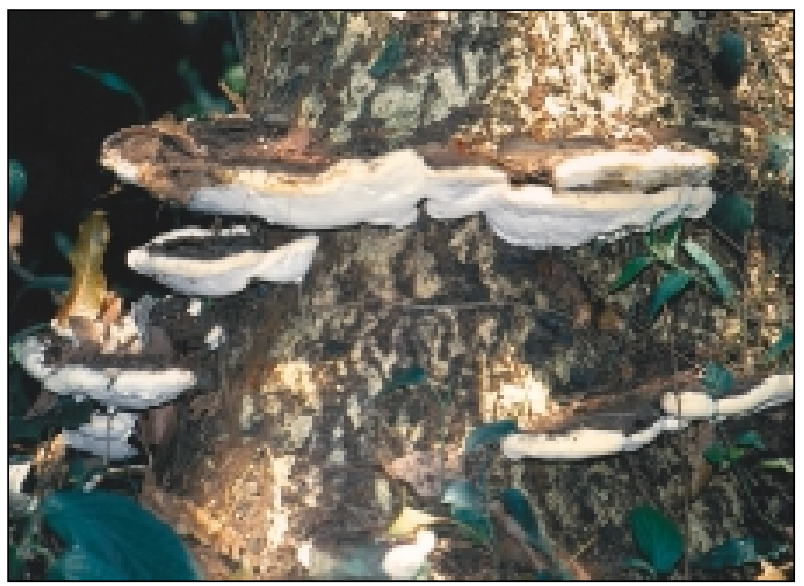

Fig. 82

Fig. 78 Phellinus noxius fruiting at the base of a tree (Peninsular Malaysia)

Figs 79-82 Ganoderma spp. fruiting on infected acacias in Peninsular Malaysia (Fig. 79): north Queensland (Fig. 80): Kerala, India (Fig. 81) and Java, Indonesia (Fig. 82) 


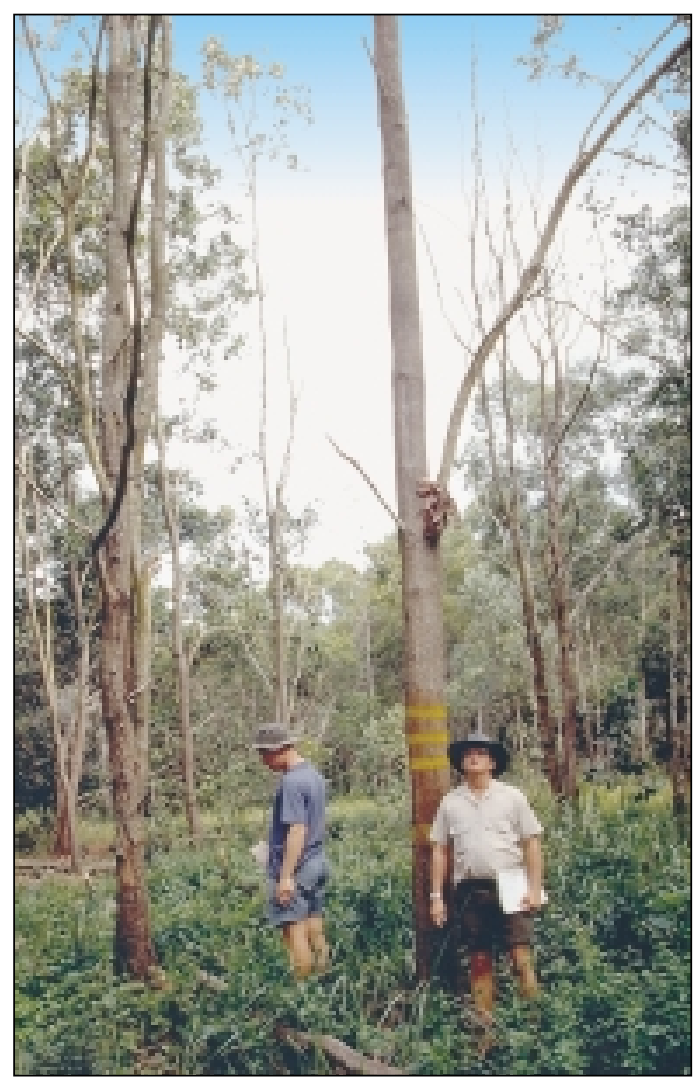

Fig. 83

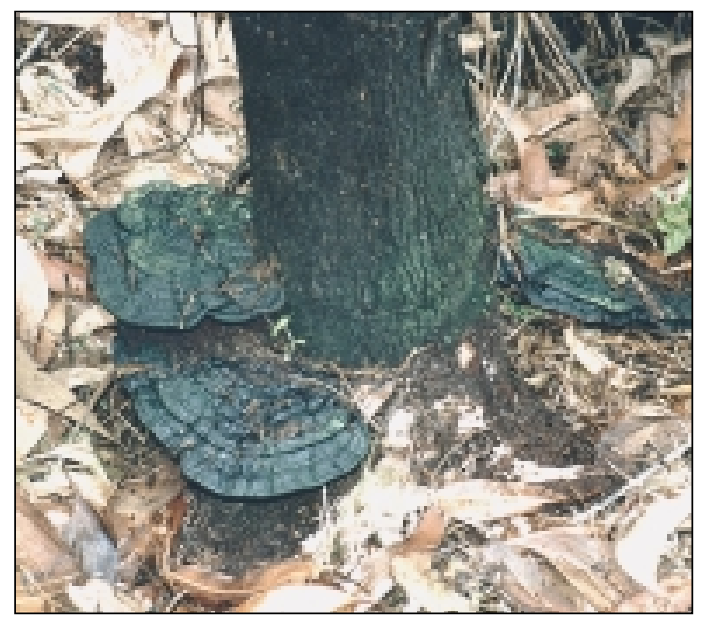

Fig. 85

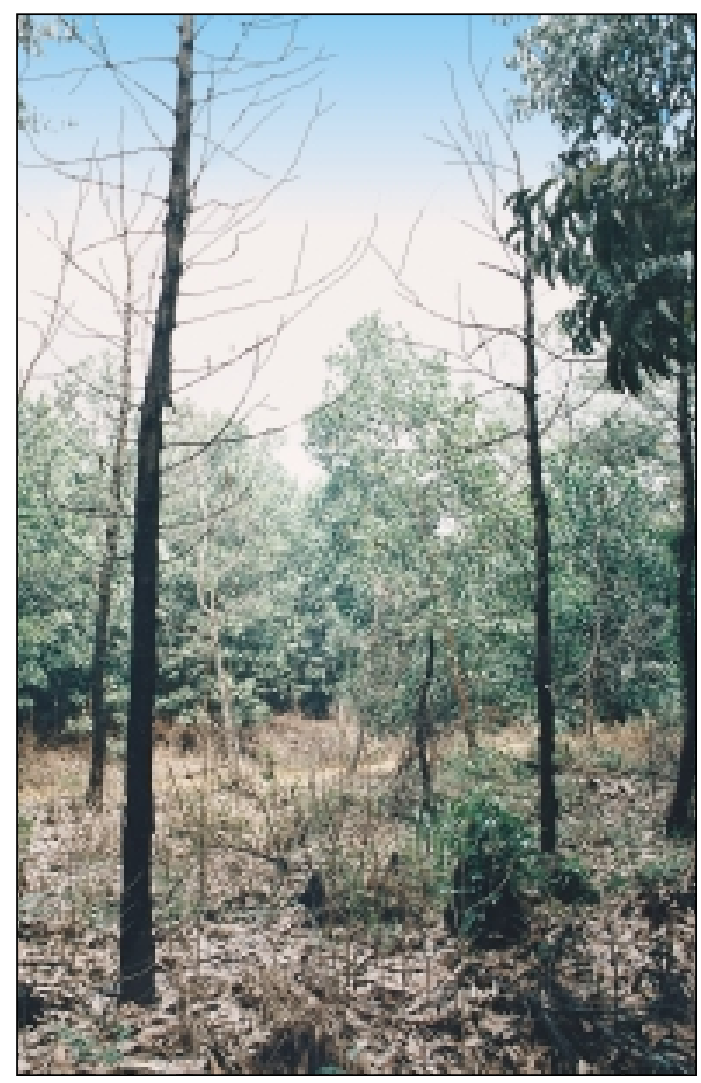

Fig. 84

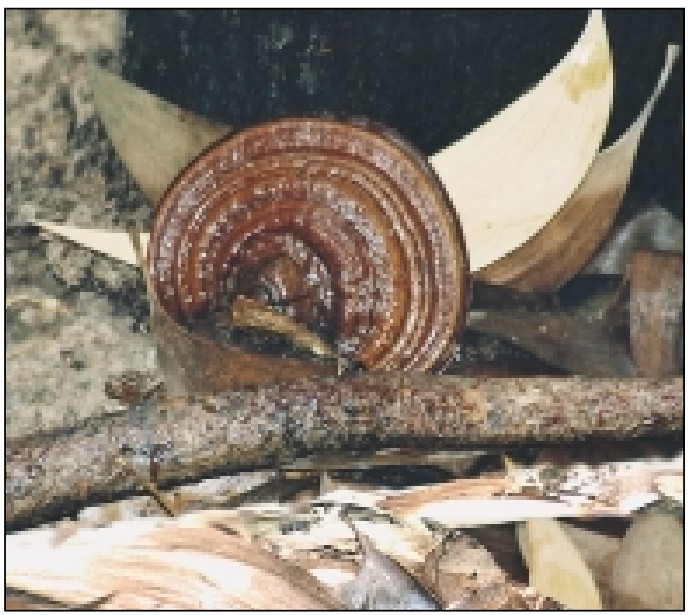

Fig. 86

Figs 83-84 Root rot disease patches in north Queensland (Acacia mangium) and central Sumatra (A. crassicarpa), associated with infection by Ganoderma spp. Dead trees are typically toward the centre of the patches, surrounded by more recently infected trees

Fig. 85 Dead tree in the second-rotation A. crassicarpa stand shown in Fig. 84 with Ganoderma sp. fruiting at the base

Fig. 86 Ganoderma sp. fruiting body, and infected root from A. crassicarpa. The root showed 'red root rot' symptoms as in Fig. 87. The Ganoderma sp. collected at this site is illustrated in Fig. 89 


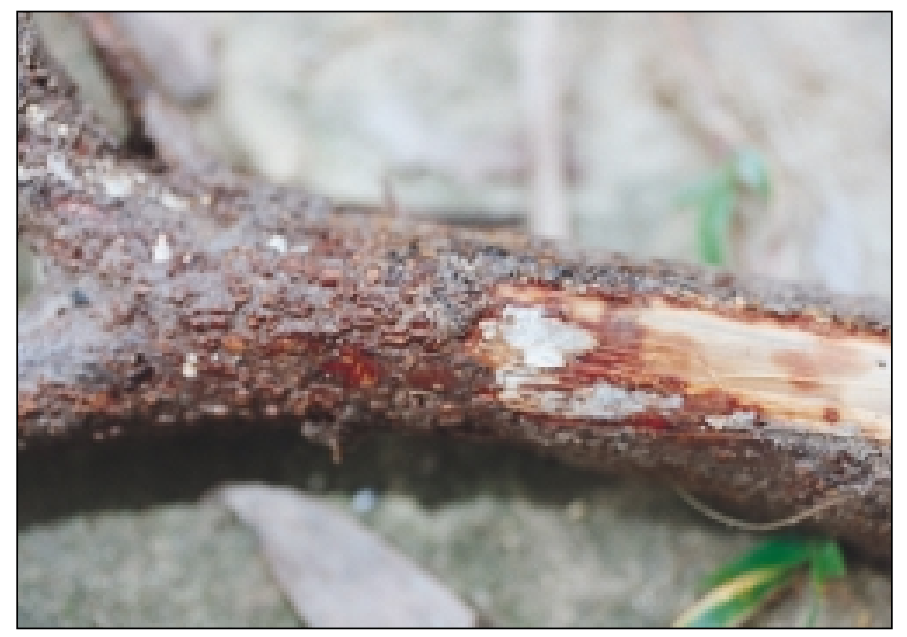

Fig. 87

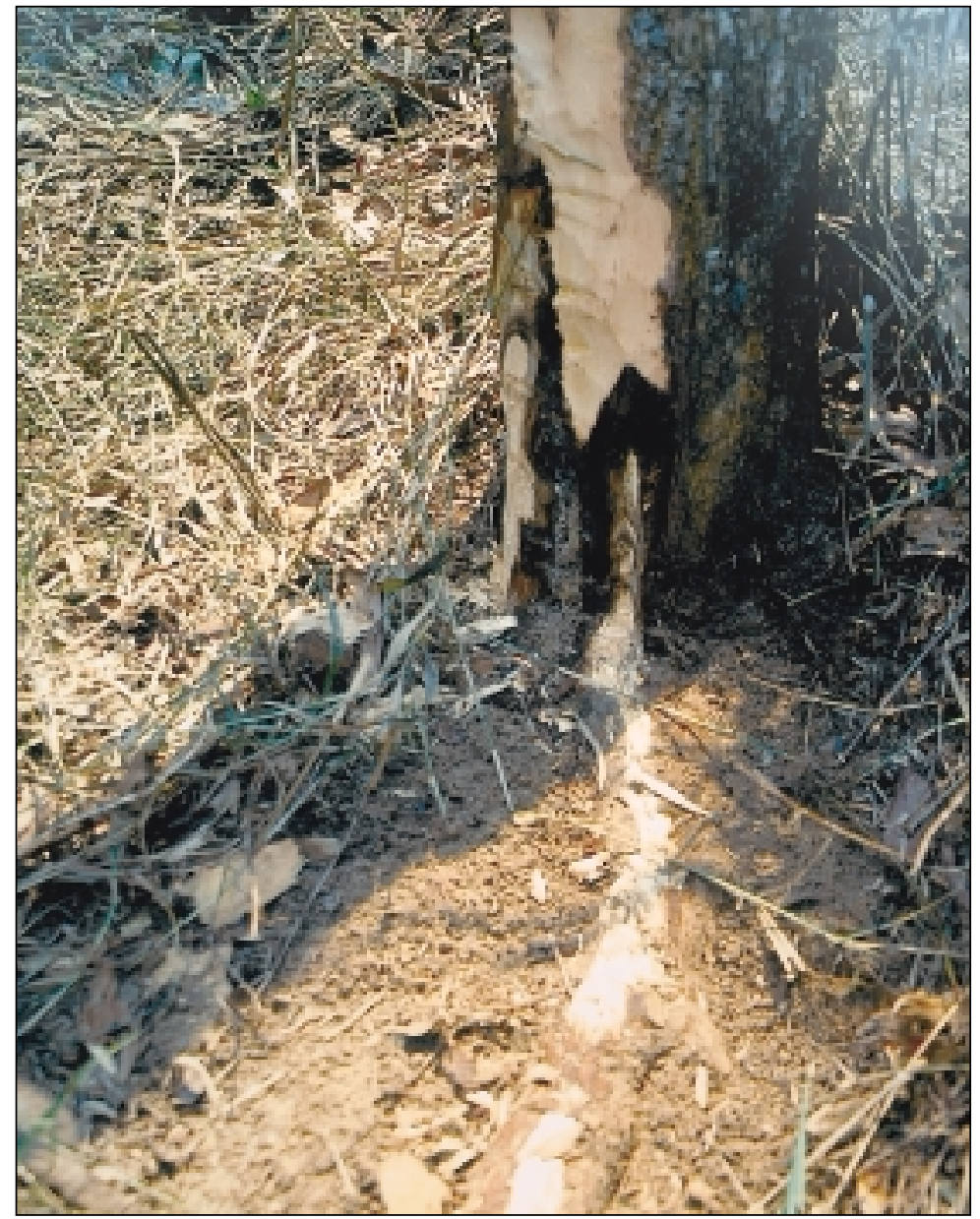

Fig. 88

Fig. 87 Red root rot showing rough, crusty surface, reddish discoloration and white mycelium under the bark

Fig. 88 Root and butt rot of A. mangium showing partial girdling of the stem base and an exposed diseased root which was a possible avenue for infection of the base of the tree (Sarawak, Malaysia) 


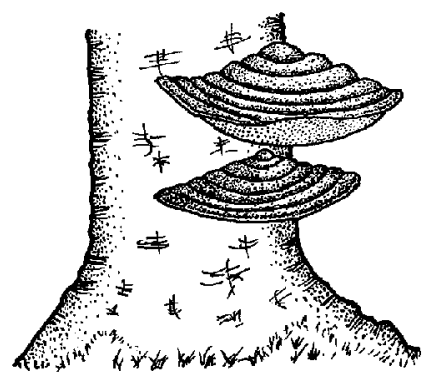

A

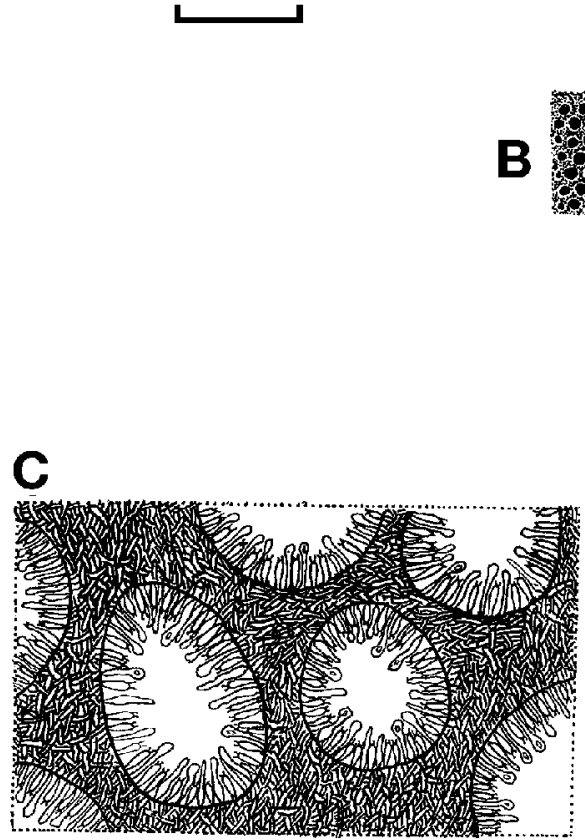

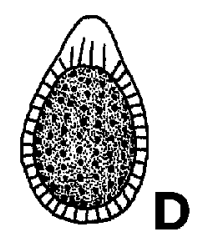
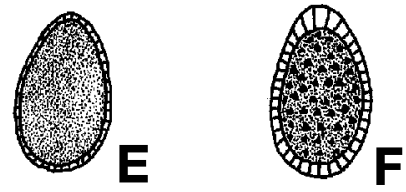
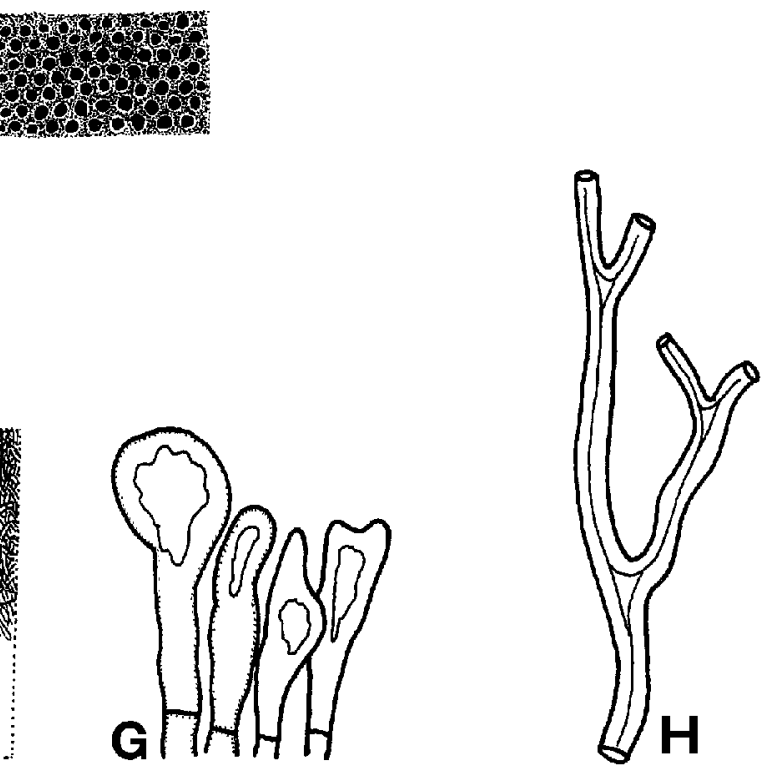

Fig. 89

Fig. 89 Ganoderma spp. on Acacia crassicarpa
A. Fruiting bodies at the base of a dead tree
B. Detail of the pores present on the underside of the fruiting bodies
C. Cross section through the pores shown in B

D-F. Basidiospores of Ganoderma spp.

G. Hyphae with swollen tips (cystidia) which project from the spore-bearing surfaces of pores and are used in identification of Ganoderma spp.

$\mathrm{H}$. Portion of the matrix of sterile hyphae that supports the pores

$(\mathrm{Bar}=1.5 \mathrm{~mm}$ for $\mathrm{B} ;=160 \mu \mathrm{m}$ for $\mathrm{C} ;=9 \mu \mathrm{m}$ for $\mathrm{D}-\mathrm{G} ;=22 \mu \mathrm{m}$ for $\mathrm{H}$; not to scale for $\mathrm{A})$ 


\section{NURSERY DISEASES}

Planting stock for large-scale plantation programs is raised in forest nurseries for several months before field planting. Location and management of the nursery are crucial in producing healthy and vigorous seedlings. Important requirements for a successful nursery operation are light-textured, fertile soil, use of a balanced potting medium with moderate $\mathrm{pH}$, an open area without any shade from trees or buildings and a good water supply.

Conventionally, in most tropical countries acacia seeds are sown in seed beds or trays after scarification or hot water treatment. Seedlings are later transferred to polythene containers and maintained in the nursery until field planting (Figs 90-91). Recently, container nurseries, where seeds are directly sown into either polythene tubes or root trainers, are becoming popular.

Numerous diseases are encountered among seedlings in beds. Disease incidence is mainly due to poor management practices, and un-hygienic conditions. These diseases may result in high seedling mortality and economic loss. Once a disease appears, it spreads rapidly under conditions of high soil moisture and close proximity of young susceptible plants. In container nurseries, fewer diseases occur and outbreaks can be readily controlled (Fig. 92).

Recently large industrial plantation companies in Indonesia, Malaysia and Thailand have established large nurseries where vast numbers of cloned plants or seedlings are produced in polypots or root trainers on elevated platforms with sophisticated watering systems and a high level of quality control.

Whether conventional nursery or container nursery, if proper management practices such as appropriate seedling density, shade, water regime and an acceptable level of hygiene are followed and good quality seed is used, disease incidence is minimised. The most common nursery diseases of acacias are powdery mildew (described earlier in this manual) and damping-off and web blight (described on pages 97-101). 


\section{DAMPING-OFF}

\section{Disease}

Damping-off, lecuh pangkal (Bahasa Malaysia), penyakit semai, rebah semai (Bahasa Indonesia)

\section{Causal organisms}

Pythium spp., Phytophthora spp., Fusarium oxysporum Schlecht. and Rhizoctonia solani Kuhn.

\section{Host range}

Damping-off affects many host species including Acacia spp. and is caused by $F$. solani, Phytophthora spp., Pythium spp. and Rhizoctonia solani (Lee 1985; Liang 1987; Maziah 1990). Damping-off of A. mangium caused by Fusarium sp. is quite common in Indonesia (Soeyamto and Mardji 1986). In Sarawak, A. auriculiformis damping-off has been caused by concurrent infection by Pythium spp. and Fusarium spp. (Chin 1995). In India, post-emergence damping-off of $A$. holosericea, caused by $F$. oxysporum, has also been reported (Soni et al. 1991). Other damping-off pathogens include Botrytis spp. and Cylindrocladium spp.

\section{Known distribution}

Damping-off probably occurs wherever tropical acacias are nursery-grown on a large scale but has been formally reported from only a few countries such as Indonesia, Malaysia and India.

\section{Symptoms}

The disease usually occurs within two weeks of seed germination causing large-scale mortality under conditions favourable for disease development, for example; densely sown seed beds or trays of seedlings; high soil moisture and humidity. Damping-off develops as irregular, spreading patches of dead and dying plants. Affected seedlings develop water-soaked, constricted stem tissue at soil level causing them to fall over and die.

\section{Pathology}

Damping-off is recognised in both pre-emergence and post-emergence stages of seedling growth and is the most common disease of forest nurseries. The pathogens are able to grow in soil, compost and other nursery potting media. Seedlings rapidly become resistant to infection due to increasing secondary thickening and lignification of stem tissue. Damping-off fungi, therefore, attack root tips, hypocotyls and young stems. Excessive watering, high humidity, shade, high seedling density and high organic content of growth media are the main factors contributing to damping-off by Pythium spp. Rhizoctonia spp. are less demanding with regard to soil moisture conditions and can cause disease under a broader range of environmental regimes (Vaartaja and Morgan 1961). 


\section{Impacts}

In well-managed hygienic nurseries, the disease is almost absent. However, under conducive environmental conditions, the disease can be very serious and result in high mortality and economic losses. Once the infection starts, it can spread very quickly and kill a large number of seedlings within a few days.

\section{Control and management}

Damping-off can be managed effectively by following appropriate nursery practices. Seedlings grown in either polypots or in root trainers are less susceptible to disease as several common damping-off pathogens do not readily spread from one container to another. Proper management of the nursery, including good hygiene and good quality water supply, are necessary to reduce disease incidence. If disease occurs, it can be controlled by reducing watering of beds to a bare minimum and by regulating shading.

Chemical treatment can become necessary to control outbreaks of damping-off. Depending upon the pathogen(s) involved, drenching with carbendazim, captan or mancozeb, applied in place of normal watering, has been found to be very effective. After treatment, control of watering to prevent excessive soil moisture helps to check further spread of the disease.

\section{References}

Chin, F.H. 1995. Damping off in some forest nurseries in Sarawak. Pathology Research Unit, Forest Research Branch, Forest Department, Kuching, Sarawak, Malaysia. Leaflet-Forest Pathology Information (Kuching) No. 2/95, 7 p.

Lee, S.S. 1985. Tree diseases and wood deterioration problems in Peninsular Malaysia. Faculty of Forestry, Agriculture, University of Malaysia. Occasional Paper No. 5, 15 p.

Liang, S.B. 1987. Research on Acacia mangium in Sabah: A review. In: Turnbull, J.W. ed. Proceedings of an international workshop, Australian Acacias in Developing Countries. Gympie, Queensland, 4-7 August 1986. ACIAR Proceedings No. 16: 164-166.

Maziah, Z. 1990. Diseases of forest plantation species in Peninsular Malaysia. In: Hutacharern, C., MacDicken, K.G., Ivory, M.H. and Nair, K.S.S. eds. Pests and Diseases of Forest Plantations in the Asia-Pacific Region. RAPA Publication 1990/9, FAO-RAPA, Bangkok, 94-99.

Soeyamto, C. and Mardji, D. 1986. Pests and diseases in nurseries and industrial forest plantations. (In Indonesian) In: Wirakusumah et al. eds. Threat on Industrial Forest Plantations. University of Indonesia, Jakarta, 100-107.

Soni, K.K., Kalyani, K.B. and Rishi, R.R. 1991. Two new diseases of Acacia holosericea from India. Myforest 27: 62-64.

Vaartaja, O. and Morgan, G.A. 1961. Damping-off etiology especially in forest nurseries. Phytopathology 51: 35-42. 


\section{Disease}

Web blight

\section{Causal organism}

Rhizoctonia solani Kuhn, teleomorph Thanatephorus cucumeris (Frank) Donk.

The genus Rhizoctonia represents a morphological group, being the mycelial state of several basidiomycete fungal genera such as Thanatephorus and Ceratobasidium (Mordue 1974). Rhizoctonia spp. are characterised by sterile mycelia with rather wide hyphae and wide-angled branching. The lateral branches are narrowed and septa occur near the junctions with the main axis of the hyphae. Isolates identified as $R$. solani are pathogenic to plants, have brown or yellow pigmented hyphae and often form discrete rounded aggregations of hyphae known as sclerotia. The teleomorphs of individual isolates are often not known and are difficult to produce on artificial media.

\section{Host range}

Web blight occurs on a wide range of woody and non-woody hosts. Reports of the disease on seedling trees in nurseries in the tropics and sub-tropics include Acacia spp., Eucalyptus spp., Albizia lebbek, Azadirachta indica, Paraserianthes falcataria, Melia azedarach, Ceiba pentandra, Lagerstroemia speciosa, Cupaniopsis anarcardiopsis and species of bamboo.

\section{Known distribution}

The disease known as web blight is less commonly reported than damping-off and seedling root rot, and probably reflects conditions especially conducive to pathogenesis. Most reports of web blight over the last few decades are from southern India (Sharma et al. 1984; Sharma and Sankaran 1991; Mohanan 1996) on eucalypts, P. falcataria, A. indica and bamboo.

There are also reports of severe damage to $M$. azedarach, A. indica and A. lebbek and seedlings of several other tree species in Assam in northern India (Mehrotra $1989 \mathrm{a}, \mathrm{b}$ ). Other reports of web blight are from Florida (McMillan et al. 1994) on C. anacardiopsis, from Virginia, on woody ornamental plants (Lambe 1982) and from Cupressus macrocarpa in Japan (Hoshi et al. 1995). Kobayashi and Oniki (1993) reported $R$. solani causing web blight in Indonesia on chrysanthemum, geranium and Mentha spp.

\section{Symptoms}

The disease is characterised by the growth of aerial mycelium of $R$. solani which proliferates from infested soil or other growing media, to attack the stems, cotyledons and young leaves of densely-spaced seedlings. The strands of mycelium are visible to the naked eye or through 
a hand lens as webs of hyphae, giving the disease its name. Light-brown irregularly shaped sclerotia form on the mycelial web. Infected seedlings develop water-soaked lesions, wilt and die. If appropriate control measures are not adopted the disease spreads rapidly to adjacent healthy seedlings.

\section{Pathology and impacts}

Rhizoctonia solani is able to grow as a saprophyte in soil or compost. The sclerotia described above are resistant to biodegradation and allow the fungus to survive in the absence of host plants. The pathogen will commonly be present in non-sterile soil or nursery media without causing significant disease. Excessive moisture due to over-watering and shade, however, coupled with high seedling density and high organic content of growth media create an environment conducive to web blight and epidemics can occur. Re-use of plastic pots or tubes without sterilisation is not recommended as the fungus can survive on contaminated containers. Impacts on seedling production can be severe, as the disease spreads rapidly.

\section{Control and management}

Web blight is more likely to be a problem where seed is sown directly into seed beds or trays of potting media rather than in nursery operations using plastic tubes or poly-pots. In the event of an outbreak, chemical treatment can become necessary for control. Drenching with carbendazim or Terrachlor (quintozene) applied in place of normal watering, is reported to be effective (Mohanan 1996; Sankaran 1996). After treatment, control of watering to prevent excessive soil moisture helps to check further spread of the disease.

\section{References}

Hoshi, H., Horie, H., Ishizuka, R. and Sato, S. 1995. Web blight of Monterey cypress is caused by Rhizoctonia solani. Proceedings of the Kanto-Tosan Plant Protection Society 42: 133-136.

Kobayashi, T. and Oniki, M. 1993. Diagnostic Manual for Industrial Crop Diseases in Indonesia. Japan International Cooperation Agency and Research Institute for Spice and Medicinal Crops, Indonesia, 107 p.

Lambe, R.C. 1982. Web blight of ornamentals. American Nurseryman 155: 105.

McMillan, R.T., Hei, H.V. and Graves, W.R. 1994. First report of web blight caused by Thanatephorus cucumeris on Cupaniopsis anacardiopsis in the United States. Plant Disease 78: 317.

Mehrotra, M.D. 1989a. Rhizoctonia web blight of Albizia lebbek: a destructive disease in forest nurseries in India. European Journal of Forest Pathology 19: 382-384.

Mehrotra, M.D. 1989b. Leaf web blight of some hardwood species in Assam and Meghalaya and its control in the nursery. Indian Forester 115: 378-384. 
Mohanan, C. 1996. Epidemiology and control of rhizoctonia web blight of bamboos. In: Nair, K.S.S., Sharma, J.K. and Varma, R.V. eds. Impact of Diseases and Insect Pests in Tropical Forests. Proceedings of the IUFRO Symposium, Peechi, Kerala, India, 23-26 November 1993, 169-185.

Mordue, J.E.M. 1974. Thanatephorus cucumeris. CMI Descriptions of Pathogenic Fungi and Bacteria. No. 406. Commonwealth Mycological Institute, Kew, England, 2 p.

Sankaran, K.V. 1996. Diseases of Paraserianthes in Kerala and their possible control measures. In: Nair, K.S.S., Sharma, J.K. and Varma, R.V. eds. Impact of Diseases and Insect Pests in Tropical Forests. Proceedings of the IUFRO Symposium, Peechi, Kerala, India, 23-26 November 1993, 134-142.

Sharma, J.K., Mohanan, C. and Florence, E.J.M. 1984. Nursery diseases of eucalyptus in Kerala. European Journal of Forest Pathology 14: 77-89.

Sharma, J.K. and Sankaran, K.V. 1991. Epidemiological studies of Rhizoctonia web blight of Albizia falcataria. Indian Phytopathology 44: 201-205. 

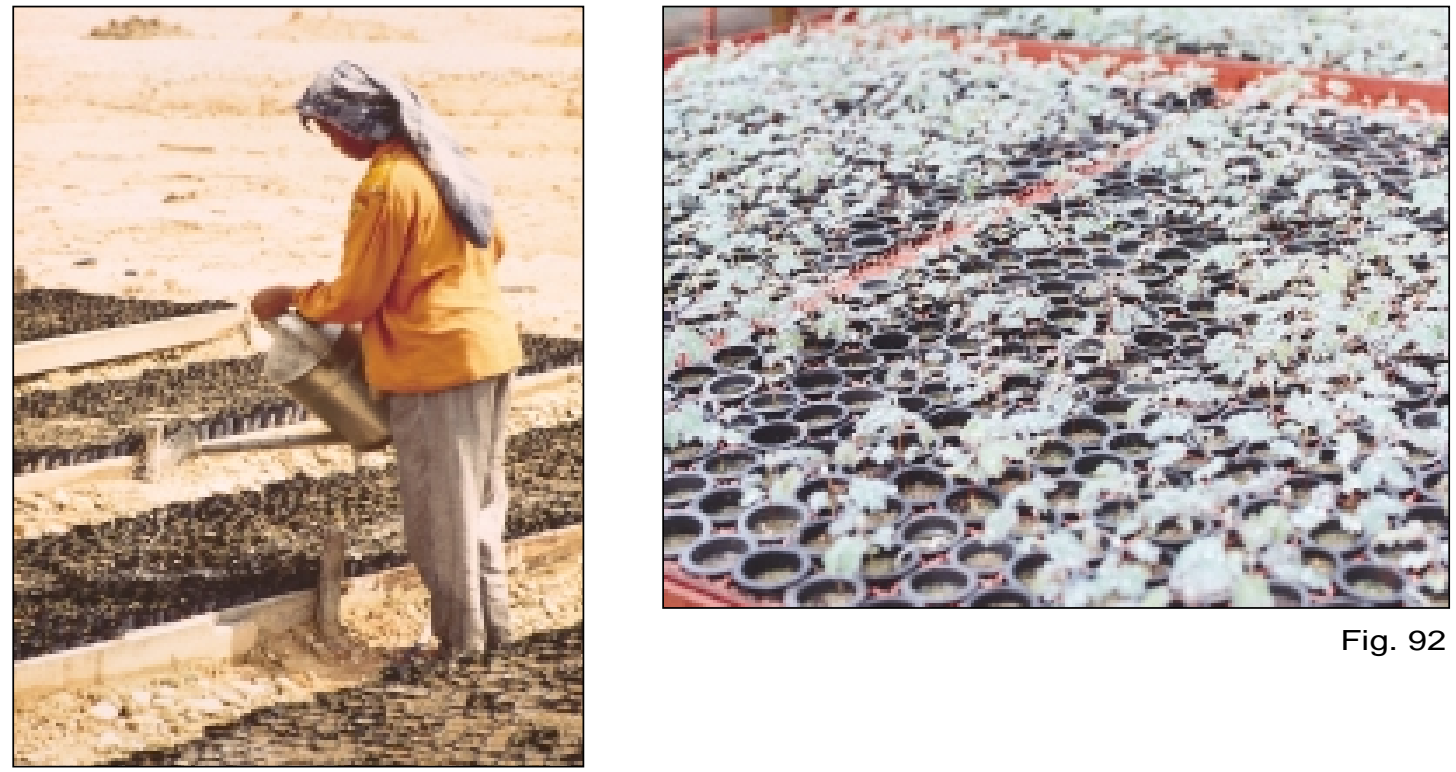

Fig. 92

Fig. 90

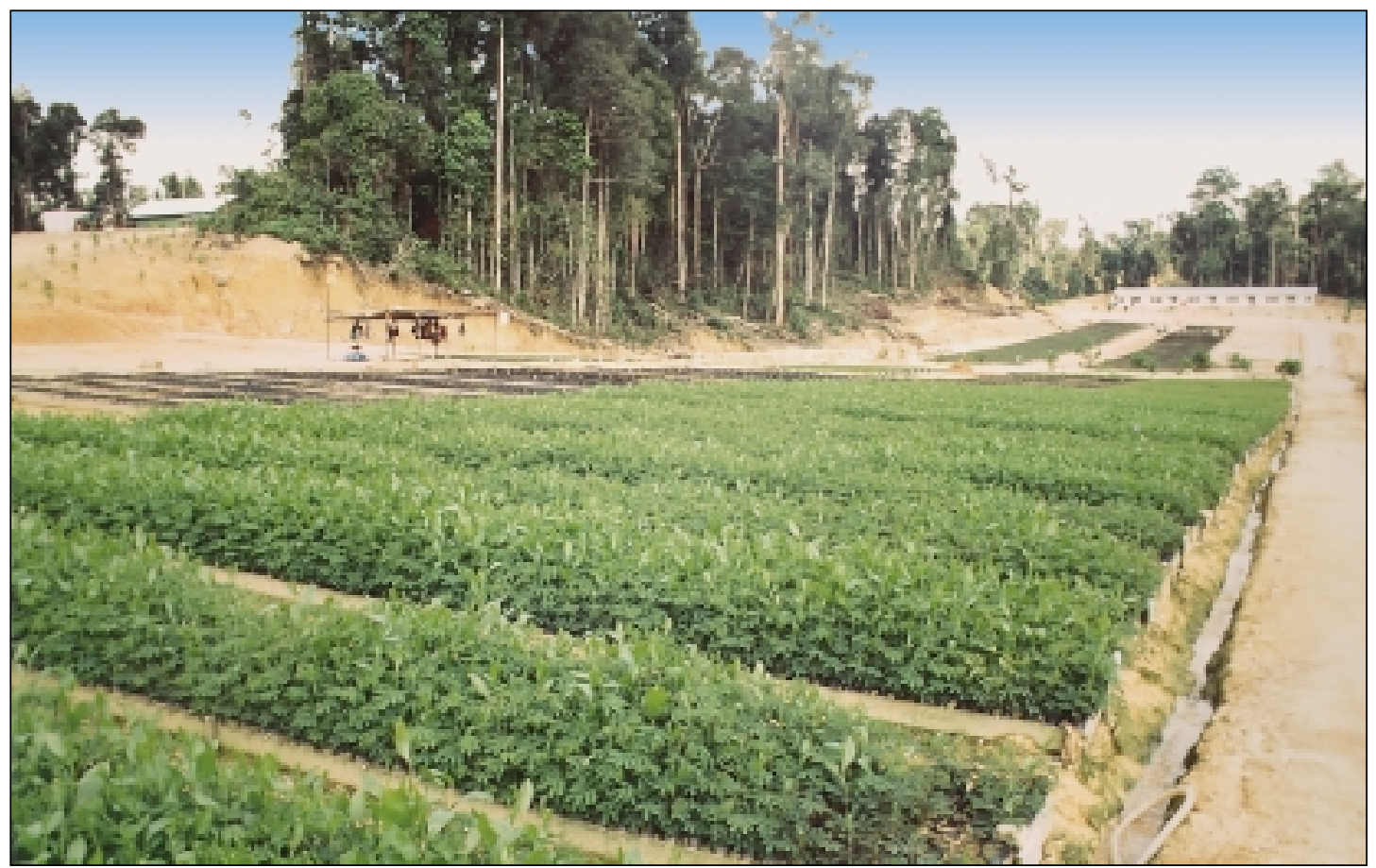

Fig. 91

Figs 90-91 Nursery operation in central Sumatra. Seedlings grown in polythene containers on the ground are shown receiving fertilizer. Although this operation was successfully raising Acacia mangium seedlings in large numbers, inoculum of soil-borne pathogens (Pythium and Rhizoctonia) would be likely to build up in beds and pathways and cause disease in the future.

Fig. 92 Acacia seedlings grown in tubes on benches in a modern nursery operation. A damping-off problem is developing (as seen from some tubes lacking seedlings). This can be easily solved by reducing watering and discarding diseased plants. 


\section{Glossary of terms}

Acervulus, (plural acervuli), a saucer-shaped fruiting structure embedded in host tissue and bearing conidia.

Anamorph, the asexual (imperfect) form of a fungus.

Annular, ring-like.

Anthracnose, a group of plant diseases characterised by the formation of discrete necrotic spots on young shoots and foliage.

Ascospore, a spore produced inside a sac-shaped ascus resulting from meiotic cell division. Characteristic of fungi classified in the ascomycetes.

Chlamydospore, an asexual spore produced primarily as a survival structure (rather than for dissemination), originating from a pre-existing cell by the formation of a thickened inner cell wall layer.

Clamp connection, a hyphal swelling that is found between adjacent cells in many basidiomycete fungi. The connection forms during cell division and is a way of maintaining the ratio of nuclei of differing genetic origin within fungal mycelia.

Conidium, (plural conidia), a specialised non-motile asexual spore produced on a conidiophore, typically for dissemination purposes.

Conidioma, (plural conidiomata), a specialised conidia-bearing structure. The term is now used widely for all such fruiting structures e.g. acervulus, pycnidium.

Microconidium, the smaller conidium produced by a fungus that also forms macroconidia.

Necrosis, the death of plant cells, often resulting in tissue becoming dark in colour.

Perithecium, subglobose or flask-shaped fruiting structure, containing asci and ascospores, formed by many ascomycete fungi.

Phialide, a specialised cell which generates a succession of conidia in basipetal succession without any increase in its own length. It is often borne on a conidiophore.

Pycnidium, a flask-shaped fruiting structure embedded in host tissue containing conidiophores and conidia.

Rhizomorph, a root-like aggregation of fungal hyphae with a well-defined apical meristem, formed by some basidiomycete tree pathogens and decomposer fungi for spreading through soils and along root surfaces.

Sclerotium, (plural sclerotia), a firm mass of fungal hyphae, often round in shape, not containing spores but often able to survive in the absence of host tissue and germinate when conditions are favourable for infection. 
Septum, (plural septa), cross walls present in fungal hyphae and spores of many species.

Seta, (plural setae), sterile hair-like hyphae which often project from spore-bearing structures, and are useful in classification.

Sporangium, (plural sporangia), a structure formed by many algae and lower fungi within which spores are formed by nuclear division and protoplasmic cleavage of the contents. Sporangia may be borne on sporangiophores.

Stroma, (plural stromata), a mass of vegetative hyphae within or on which spores or fruiting bodies are formed.

Teleomorph, the sexual (perfect) form of a fungus.

Thallus, the vegetative body of fungi and other thallophytes.

Vesicle, a sac-shaped structure which may be the swollen apex of a conidiophore or a sterile hypha as in Cylindrocladium; also used to describe a wide range of structures found in plant and animal tissues and cells. 
A major expansion of tropical acacia plantations for industrial use has occurred in recent decades, especially in South-East Asia and also in India. The most widely planted species have been Acacia mangium and A. auriculiformis. Trial plantings of $A$. crassicarpa and A. aulacocarpa have also been established in many locations. The authors of this manual, with their colleagues and with pathologists from Thailand and Indonesia, have surveyed plantations of these species in northern Australia, Indonesia, Malaysia, Thailand and southern India to determine the main diseases present. This manual provides plantation managers and forest health practitioners with short, illustrated accounts of diseases of tropical acacia plantations. A simple key, based on disease symptoms, leads the reader to descriptions of pathogens, photographs of disease symptoms and mycological drawings which will assist in diagnosis of disease. Information is also provided on disease impacts, control and management.
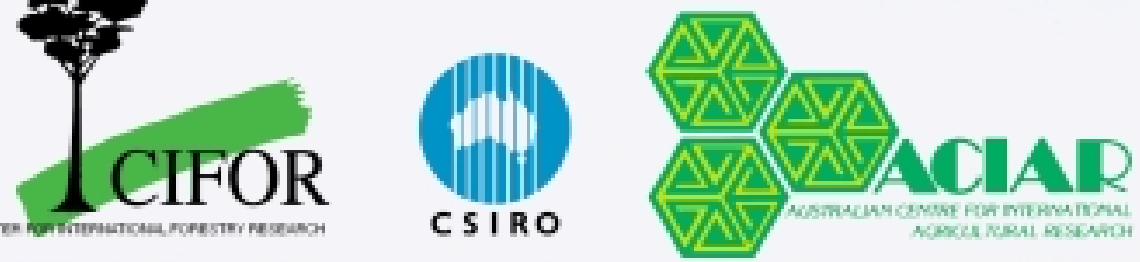